\title{
IDENTIFICAÇÃO DE COMPETÊNCIAS ESSENCIAIS PARA FORMAÇÃO E GERÊNCIA DE REDES DE EMPRESAS DA CONSTRUÇÃO CIVIL
}

Dissertação apresentada a Escola
de Engenharia de São Carlos da
Universidade de São Paulo, como
parte dos requisitos para a obtenção
do título de mestre em Engenharia
de Produção.

Orientador: Prof. Dr. Fábio Müller Guerrini

SÃO CARLOS

2005 
Dedico esta dissertação aos meus pais Aristides e Antonieta e aos meus irmãos André e Augusto, pelo amor e incentivo a mim sempre dados e à Claudia , pelo afeto e companheirismo em todos os momentos. 


\section{AGRADECIMENTOS}

A Deus, por me dar esta oportunidade.

Ao Prof. Dr Fábio Müller Guerrini, pela sua constante orientação ao trabalho e por sua amizade e paciência durante todo meu período de pós graduação.

A todos os companheiros do grupo de pesquisa, pelo auxilio e amizade.

À Profa. Dra. Sheyla Mara Baptista Serra e ao Prof. Dr. Fernando César Almada Santos, por terem participado do meu exame de qualificação e defesa contribuindo para confecção deste trabalho.

À Profa. Dra. Ruth de Gouvêa Duarte, pela revisão deste trabalho.

Aos professores do Departamento de Engenharia de Produção, pelas valiosas explanações e reflexões.

Aos funcionários do Departamento de Engenharia de Produção, pelo apoio e atenção.

Aos amigos de pós graduação, pela amizade e ajuda.

A CAPES, pela bolsa concedida.

A todos os colaboradores da Companhia do metropolitano de São Paulo, pelo espaço e atenção dada para a realização do estudo de caso.

Aos amigos da turma de graduação, pela amizade e companheirismo.

A todos que, de maneira direta ou indireta , contribuíram para a realização deste trabalho. 


\section{RESUMO}

ROSSETTI, Anibal Martins (2005). Identificação de competências essenciais para formação e gerência de redes de empresas da construção civil. Dissertação (Mestrado em Engenharia de Produção) - Escola de Engenharia de São Carlos, Universidade de São Paulo, São Carlos.

No setor da construção civil as perspectivas gerenciais das organizações são de adaptar-se aos novos cenários e uma das formas é a de formar redes de empresas. Para formar e gerenciar redes de empresas é necessária a adequação de competências essenciais, pois organizações bem sucedidas são aquelas que demonstram desenvolver suas competências essenciais para oferecer padrão de excelência em bens e serviços. Neste trabalho são analisadas as propostas e os possíveis desdobramentos sobre o escopo compreendendo o processo de formação de redes de empresas e posteriormente é sugerida uma sistematização para identificar as competências essenciais para a formação e gerenciamento de redes de empresas da construção civil, empresas estas que possuam objetivos comuns e que mantenham a independência e individualidade para, assim, formar uma rede que permita a realização de ações conjuntas, facilitando a solução de problemas comuns e viabilizar novas oportunidades. As empresas por fim identificadas unem-se em uma rede e conseguem reduzir custos, dividir riscos, conquistar novos mercados, qualificar produtos e serviços e ter acesso à novas tecnologias. A aplicação prática do trabalho é feita através de um estudo de caso exploratório em uma obra de construção civil buscando as competências contidas nas empresas participantes para, assim, poder afirmar quais são as competências essenciais para formação da rede e quais poderão trazer benefícios à mesma ou a outras que virão a se formar. Espera-se com o resultado desta pesquisa determinar quais empresas são capazes de operar em um negócio em forma de rede de empresas, envolvendo profunda avaliação de competências essenciais, verificando se as mesmas irão garantir uma adequada sustentação competitiva nos mercados almejados.

Palavras chave: Redes de empresas, competências essenciais, construção civil. 


\section{ABSTRACT}

ROSSETTI, Anibal Martins (2005). Identification of core competences to formation and management of enterprise networks in civil construction. Dissertation (Master in Production Engineering) - School of Engineering of São Carlos, University of São Paulo, São Carlos.

In the civil construction, the management perspectives of organizations are to adapt to new sceneries and one of the ways is to create enterprise networks. To create and management enterprise networks it is necessary the adequation the core competence, because well succeeded organizations are those which demonstrate to develop its core competences to offer excellent standards in goods and services. In this work proposals and possible results of the issues concerning to the process of networks formation area analyzed. It is also suggest a systematization to identify core competence to the formation and management of enterprise networks in civil construction sector that have common goals and maintain the independence and individuality, to create a network that allows the accomplishment of joined actions, making the solution of common problems easier and making new opportunities feasible. These enterprises, finally identified, join themselves in a network and can reduce costs, divide risks, reach new markets, qualify products and services, and have access to new technologies. The practical application of this work is done throughout a case study which explores a civil construction task arming to identify the competence inserted in the participate enterprise, that it will be possible to affirm which the core competence to the formation of the network and which are able to bring benefits to itself and to others enterprise networks. It is intended, as a result of this research, to determine which enterprises are capable to operate in a new business, in a network configuration, involving deep evaluation of core competences and verifying if they will guarantee a competitive sustentation in desired markets.

Keywords: Enterprise network, core competences, civil construction. 


\section{LISTA DE FIGURAS}

Figura 1 - Etapas relevantes para elaboração de um estudo de caso (YIN, 2001)................... 14

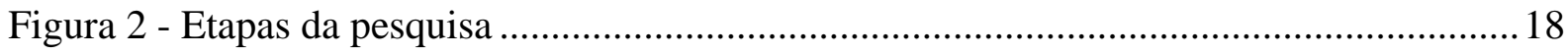

Figura 3 - Estrutura vertical das índustrias (FINE e WHITNEY, 1996)..................................21

Figura 4 - Estrutura horizontal das índustrias (FINE e WHITNEY, 1996)..............................22

Figura 5 - Competências, relação entre habilidades e tarefas (TERHAAG et al., 1996)......... 30

Figura 6 - A hierarquia de competências (JAVIDAN, 1998) ................................................. 31

Figura 7 - Níveis de abstração de competências essenciais (HAMEL e HEENE, 1994)..........34

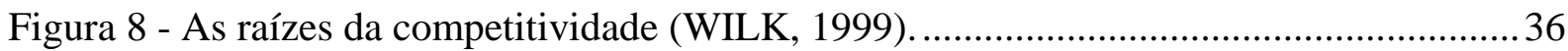

Figura 9 - Reunião e distribuição das competências essenciais (BOGNER , THOMAS e

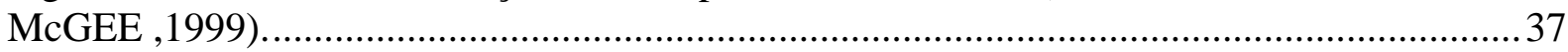

Figura 10 - O modelo de transformações (MACHADO e HEINECK, 2003)...........................41

Figura 11 - Rede formada pelos dois consórcios participantes da execução da obra................ 71

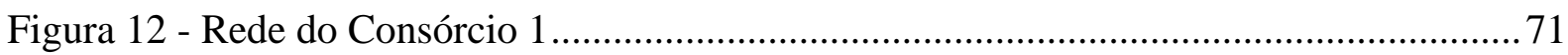

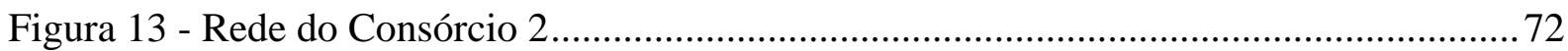

Figura 14 - Localização das competências essenciais dentro da rede...................................... 73

Figura 15 - Localização das competências essenciais das empresas subcontratadas dentro da

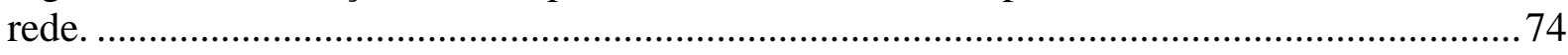

Figura 16 - Níveis de abstração de competências essenciais na obra do metrô. ...................... 79

Figura 17 - Reunião e distribuição das competências essenciais na obra do metrô .................. 80

Figura 18 - Representação gráfica dos submodelos e seus respectivos elementos. ................. 93 


\section{LISTA DE QUADROS}

Quadro 1 - Elementos estruturais das redes de empresas (BRITTO, 2002a).......................... 25

Quadro 2 - Competências inseridas no processo de construção civil......................................45 


\section{LISTA DE ABREVIATURAS E SIGLAS}

BIRD - Banco Internacional para Reconstrução e desenvolvimento

CCR - Concreto Compactado a Rolo

CMSP - Companhia do Metropolitano de São Paulo

CPM - Critical Path Method (Método do Caminho Crítico)

CPTM - Companhia Paulista de Trens Metropolitanos

EESC - Escola de Engenharia de São Carlos

EKD - Enterprise Knowledge Development

IGBT - Insulated Gate Bipolar Transistor

JBIC - Japan Bank for International Cooperation

LAN - Rede local

NATM - New Austrian Tunneling Method

TGV - Trens de alta velocidade

WI-FI - Rede wireless

GSM - Global System Móbile 


\section{SUMÁRIO}

1. INTRODUÇÃO ..................................................................................................................... 11

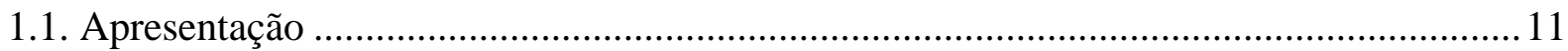

1.2. Caracterização do tema............................................................................................... 11

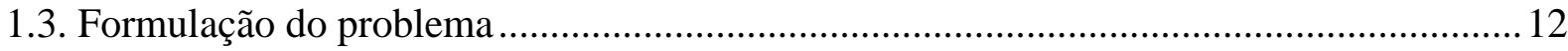

1.4. Objetivo da pesquisa........................................................................................... 12

1.5. Justificativa do tema ................................................................................................ 12

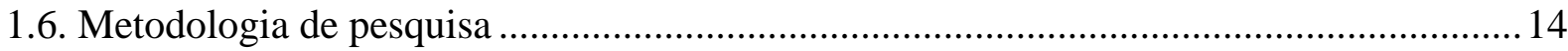

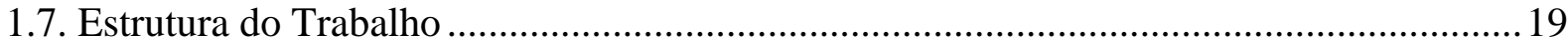

2. REDES DE EMPRESAS PRODUTIVAS .....................................................................20

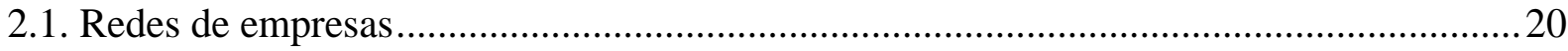

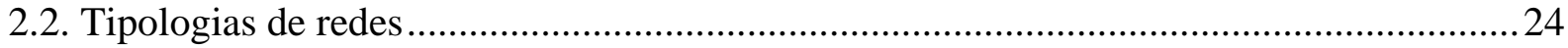

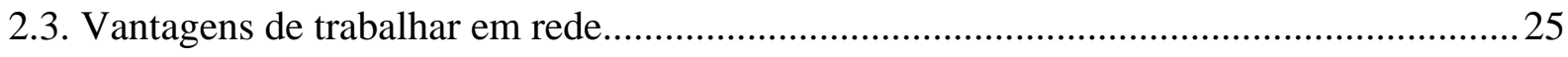

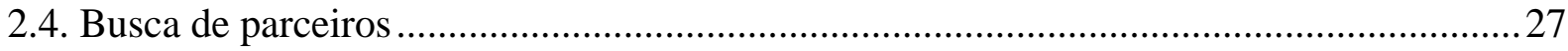

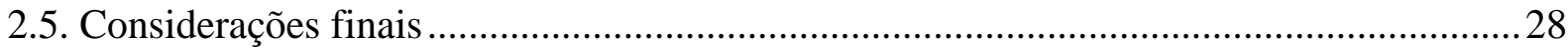

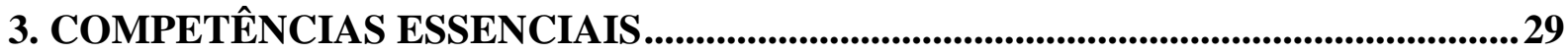

3.1. Hierarquia de competências essenciais........................................................................... 29

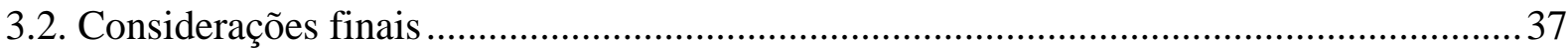

4. O SETOR DA CONSTRUÇÃO CIVIL..........................................................................39

4.1. O processo de execução de obras na construção civil ........................................................... 39

4.2. Considerações finais ................................................................................................... 44

5. COLETA DE DADOS........................................................................................................... 46

5.1. Apresentação da obra do metrô - Linha 4, Amarela............................................................46

5.2. As empresas dos consórcios ..................................................................................... 50

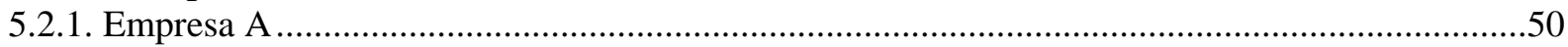

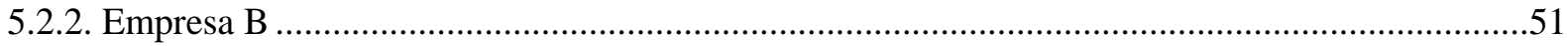

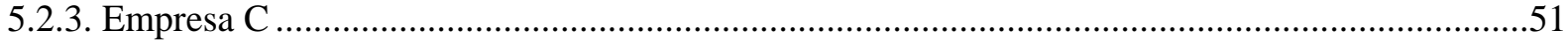

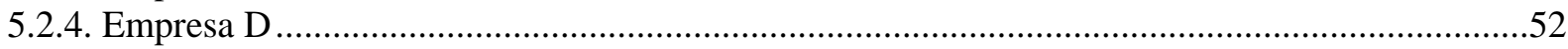

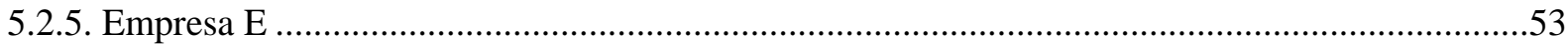

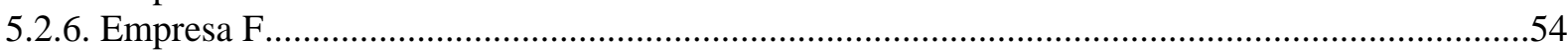

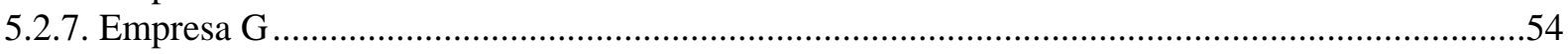

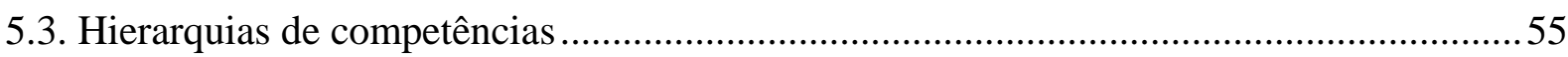

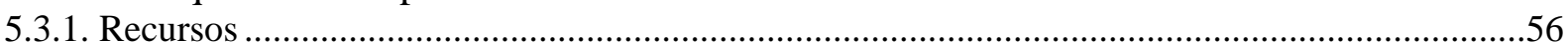

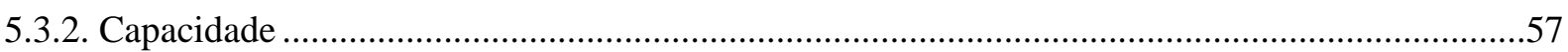

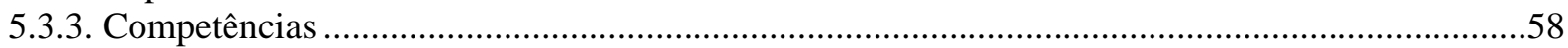




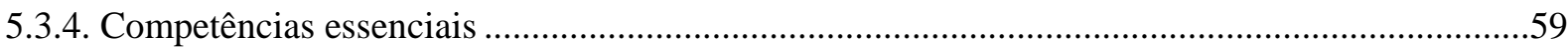

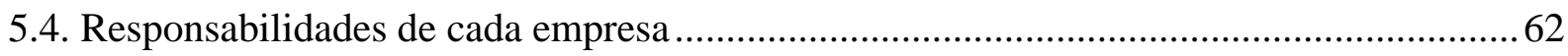

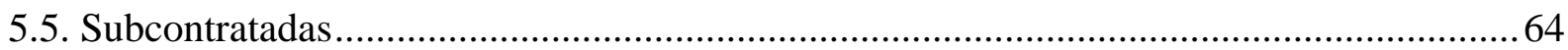

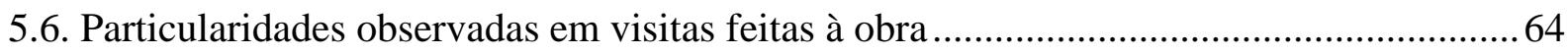

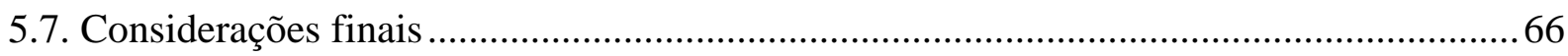

6. ANÁLISE DE DADOS E RESULTADOS ...............................................................67

6.1. Caracterização dos consórcios sob a ótica de redes de empresas....................................67

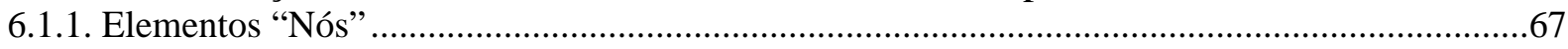

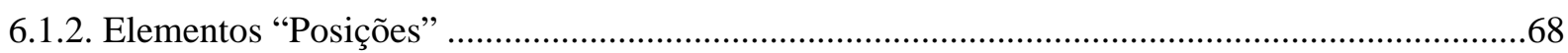

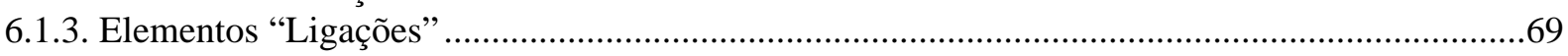

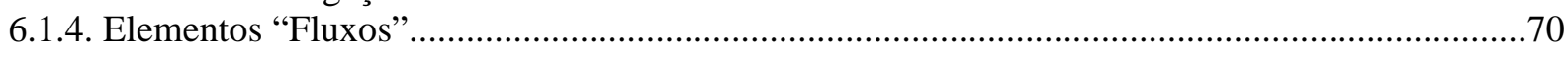

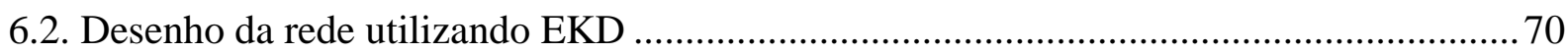

6.3. Sistematização do processo de identificação de competências essenciais ........................ 75

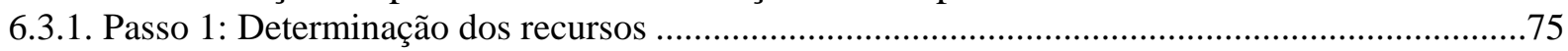

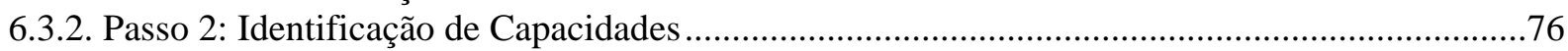

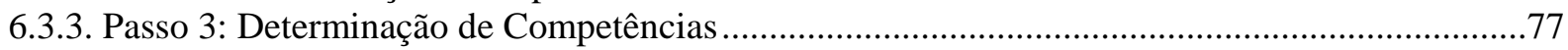

6.3.4. Passo 4: Determinação de Competências Essenciais …………………….......................................77

6.3.5. Passo 5: Combinação de Competências Essenciais............................................................................78

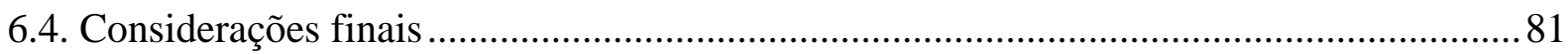

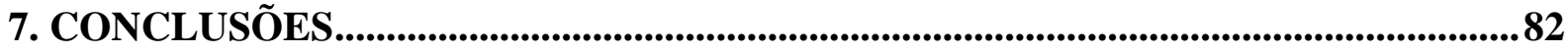

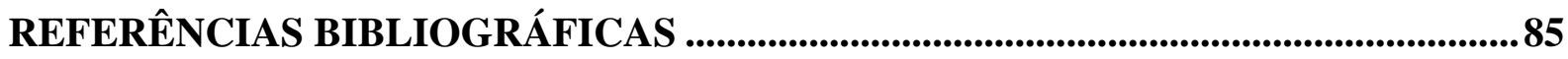

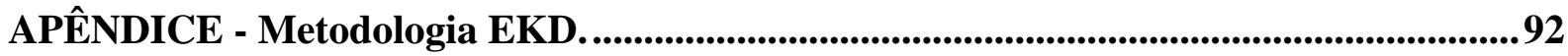

ANEXO A - Mapa da linha amarela da rede do metrô da cidade de São Paulo...............95 


\section{INTRODUÇÃO}

Este capítulo apresenta as características que motivaram o estudo e desenvolvimento deste projeto, seus objetivos, sua estrutura e suas etapas de pesquisa.

\subsection{Apresentação}

O nível de concorrência entre as empresas nacionais e entre empresas nacionais e estrangeiras tem aumentado significativamente, pois ocorreram grandes transformações no mercado, ao qual a competitividade dos produtos levou os setores públicos e privados a buscarem novas formas de se organizarem para aumentar a produtividade. Para poderem sobreviver, as empresas têm buscado adaptarem-se permanentemente, reestruturarem-se e buscarem formas de inovação dentro de novas configurações. Isto implica em mudanças na estratégia das organizações a partir da necessidade de reunir recursos por meio de estratégias colaborativas para adquirirem habilidades que ainda não possuam e formarem ligações que podem assumir uma variedade de formas, dentre elas, a atuação em redes.

Este trabalho dá continuidade ao projeto, "Formação e gerencia de redes de empresas de construção civil” em andamento no âmbito do Departamento de Engenharia de Produção da Escola de Engenharia de São Carlos da Universidade de São Paulo (EESC-USP). Alguns outros grupos de pesquisa destacam-se no estudo de redes de empresas, entre eles o Redes de Cooperação e Gestão do Conhecimento (REDECOOP) vinculado à Escola Politécnica da Universidade de São Paulo, que tem como coordenador o professor João Amato Neto (REDECOOP, 2004), o ESPRIT (The EU information technologies (IT) programe), que é administrado pelo Diretório Geral da Indústria da Comissão Européia (ESPRIT, 2004).

\subsection{Caracterização do tema}

A inovação é um importante critério para que uma empresa se torne competitiva. Segundo Hamel e Prahalad (1995), a inovação vista como “chegar primeiro ao futuro” pode garantir, a uma empresa, definir padrões e regras que outras empresas devem seguir para poderem 
participar de uma competição. A meta para as empresas é minimizar tanto o tempo quanto o investimento necessário para tanto.

Os benefícios que podem provir das atividades de uma rede de empresas podem ser muito relevantes, mas é preciso preocupar-se permanentemente com a manutenção dos atores (empresas) que se reúnem e com a satisfação de suas necessidades. As características legais e estruturais das redes poderão ser uma conseqüência do seu desenho organizacional, isto é, derivadas do acordo entre as empresas, dos objetivos, dos tipos de serviços desenvolvidos e da profundidade dos mesmos.

A busca de empresas para estas redes não se sistematiza ou, pelo menos, não é descrita como forma de estabelecer-se uma rede que propicie benefícios. Assim, a proposta de Hamel e Prahalad (1995), que considera as competências essenciais uma característica-chave para o crescimento da empresa pode ser um fator importante na formação de redes de empresas. A busca de competências essenciais pode ser a chave para a formação de redes de empresas que produzem de forma a não apenas desenvolver e concluir uma obra, mas, de maneiras diferentes, inovadoras e com eficiência, desenvolver soluções de problemas em menor tempo e com menor custo. O objetivo comum é a obtenção de um produto final com uma qualidade diferenciada e com um custo menor, o que torna o conjunto todo mais competitivo.

\subsection{Formulação do problema}

Para a formação de uma rede de empresas produtiva é indispensável a seleção e coordenação da infra-estrutura necessária, ou seja, identificar quais empresas podem fazer parte da mesma. A união aleatória de empresas, para suprir essa infra-estrutura, pode prejudicar o andamento de uma obra de construção.

\subsection{Objetivo da pesquisa}

Propor uma sistematização do processo para identificar as competências essenciais necessárias à formação e gerência de redes de empresas produtivas de construção civil a partir de um estudo de caso de caráter exploratório em uma obra de construção civil de grande porte.

\subsection{Justificativa do tema}

A formação de redes de empresas tem trazido significativos ganhos para as empresas que dela participam. Combinar competências e conhecimento, exercer maior pressão sobre o mercado é uma das principais metas de trabalhar em rede (AMATO NETO, 2000). 
Segundo Fleury (1997), as estratégias de empresas brasileiras têm exigido enorme esforço para firmar as redes de empresas. Tais uniões têm se tornado de grande importância não só para a transferência de tecnologia mas, principalmente, para facilitar o acesso aos principais mercados do mundo.

As relações interempresas são uma das principais tendências da economia moderna, principalmente para as pequenas e médias empresas, pois facilita a estas a participação no mercado de grandes empresas. Amato Neto (2000) reporta que esta experiência funciona com êxito em países como o Japão, onde as pequenas e médias empresas possuem grande significado na economia do país, e na região nordeste da Itália onde as empresas atuam de forma cooperada em um mercado bastante dinâmico. Para Amato Neto (2000) as grandes empresas serão forçadas a possuir maior descentralização produtiva a estarem apoiadas em uma base industrial de pequenas e médias empresas muito mais dinâmicas.

Casarotto (2002) explica que no Brasil, especialmente na Construção Civil, as grandes empresas já realizam a união de empresas para executar grandes obras e as pequenas empresas parecem estar à margem dessa nova tendência. Assim, torna-se necessário um método para auxiliar as empresas da construção a viabilizarem a gestão baseada na cooperação entre as empresas.

O processo desenvolvimento de uma rede de empresas de construção é extremamente importante, porém não é conduzido de forma a explorar todas as suas potencialidades. Essa situação parece agravar-se ainda mais em pequenas e médias empresas de construção que, geralmente, são conhecidas por trabalharem com restrições de recursos ou com uma carga de trabalho excedente para sua capacidade (BERNARDES e FORMOSO, 2000).

Isso acentua a necessidade e a importância das organizações atuarem de forma mais conjunta, buscando parcerias e formando redes com outras organizações para assim adquirir as devidas condições de sobrevivência e desenvolvimento. Neste sentido, a empresa precisa identificar e definir qual a melhor forma de concepção e estabelecimento dessas redes. Para tanto ela precisa buscar conhecimento e identificar competências necessárias para seu negócio. Para Goulart (2000), empresas que querem trabalhar em rede têm que se concentrar em competências essenciais e, conseqüentemente, precisam cooperar para complementarem as competências necessárias.

Corrêa (1999) refere que um dos principais obstáculos para formação de rede é a escolha de parceiros. Assim, torna-se plausível e necessário, o estudo de competências essenciais em redes de empresas de construção civil. 
A concorrência e a competitividade no atual ambiente exige que as empresas busquem a cada vez, aumentar sua eficiência operacional e desenvolver novas competências. A capacidade de aprender em redes com outras empresas e parceiros constitui um importante diferencial (BRASILEIRO NETTO, FREITAS e NOVAES, 2003).

As respostas às indagações levantadas durante a pesquisa devem promover benefícios às empresas observadas, na medida em que confirmem a validade da pesquisa, colocando em proposições estratégicas ou, caso contrário, apenas alertando a sua adequação. Pretende-se encaixar estas competências essenciais para comunicação e envolvimento para trabalhar por meio da cooperação entre as diferentes competências, de forma que estas consigam reconhecer as oportunidades de juntarem suas habilidades técnicas com as de outras empresas.

\subsection{Metodologia de pesquisa}

Para propor-se a resolução do problema de pesquisa foi realizada uma investigação direcionada a um processo produtivo existente. Para a resolução do problema neste processo existente foi necessário desenvolver um estudo de caso de caráter exploratório. Posteriormente foram convertidas as situações encontradas e observadas em informações estruturadas.

Segundo Yin (2001), o estudo de caso constitui uma investigação de fenômenos contemporâneos dentro de seu contexto real, em que os limites entre o fenômeno e seu contexto não são claramente evidentes.

Assim, a estratégia de pesquisa adotada constituiu em observar-se fenômenos reais com o intuito de interpretá-los criticamente. Foi realizado um estudo de caso baseado em interpretações de fatos ocorridos e relatados no mundo real de uma obra de construção de grande porte. A Figura 1 apresenta as etapas relevantes para a elaboração do estudo de caso.

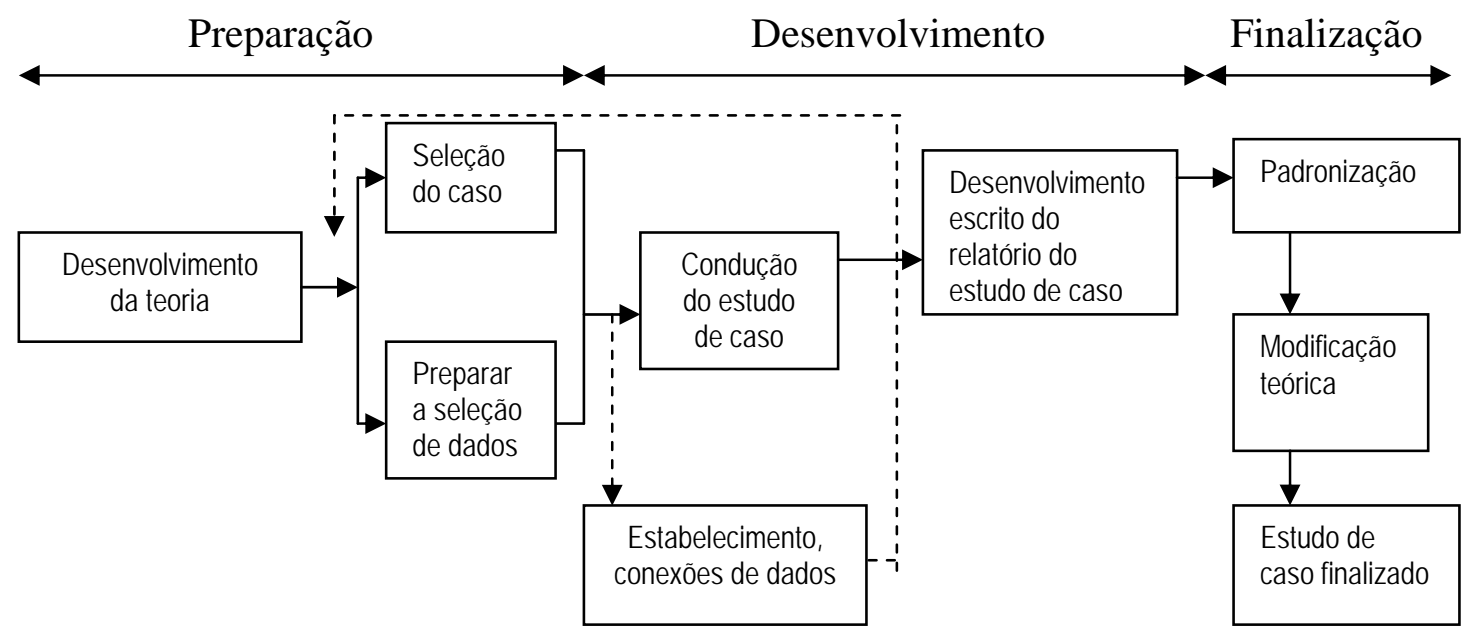

Figura 1 - Etapas relevantes para elaboração de um estudo de caso (YIN, 2001). 
O estudo de caso foi a estratégia escolhida porque alguns aspectos não poderiam ser respondidos sem este estudo, por exemplo, as características políticas e de relacionamento de confiança, como indicações, privilégios e vantagens que se estabelecem fora de uma documentação ou relatórios burocráticos. Demonstrar realmente como e porque se estabelecem as relações entre as competências da rede mostraram a necessidade de se realizar o estudo de caso.

Por fim, o estudo de caso tem o intuito de confrontar como é realmente feita a identificação de competências em uma rede de construção com o que a teoria diz a respeito para, assim, estabelecer-se uma forma de identificar competências essenciais.

Ao longo da pesquisa foram utilizadas diversas técnicas de coleta de dados. Segundo Yin (2001), o uso de fontes múltiplas de coletas de evidências constitui um dos princípios fundamentais do desenvolvimento de estudos de casos bem sucedidos. Para Yin (2001), isto se deve à necessidade de viabilização do fundamento de pesquisa da triangulação, que consiste na investigação de fontes distintas em busca de evidências associadas a um mesmo fenômeno.

O estudo de caso foi realizado em uma obra de construção de grande porte com relacionamentos formais e informais e que se unem de acordo com oportunidades do mercado.

O estudo de caso envolve um levantamento bibliográfico documental e entrevistas não estruturadas. Foram feitas visitas às obras e analisados documentos relacionados. As fontes foram os documentos do planejamento da obra como projetos, memoriais, além de observações diretas. Também foram feitas entrevistas com as pessoas responsáveis pelos processos.

Dentre as fontes de evidências propostas por Yin (2001), foram utilizadas neste trabalho as seguintes: análise de documentos, análise de registros em arquivos, entrevistas, observações diretas.

Segundo Yin (2001), as informações documentais são relevantes a, provavelmente, todos os tipos de estudos de caso. O uso mais importante de documentos é validar as evidências oriundas de outras fontes na pesquisa. Além disso, também é possível fazer-se inferências se alguma prova documental contradisser algum dado prévio.

Foram analisados documentos que descrevem as estruturas organizacionais das empresas estudadas e todo o planejamento da obra, procedimentos, documentos de execução de serviços e planos de produção. A análise do planejamento da obra tende a recolher informações sobre as empresas, tais como missão, visão, expectativas ou desejos dos clientes, 
objetivos estratégicos das empresas, com a finalidade de identificar quais são as necessidades das redes.

Os registros em arquivos eletrônicos forneceram informações sobre os serviços realizados, tabelas e listas de itens importantes, dados oriundos de levantamentos.

Yin (2001) considera a entrevista uma das mais importantes fontes de informações para um estudo de caso. Segundo Yin, as entrevistas são fontes de evidências essenciais no desenvolvimento de estudos de caso; entrevistadores bem informados podem dar interpretações importantes para uma determinada situação. Uma de suas principais vantagens é complementar informações obtidas em outras fontes.

Nesta pesquisa as entrevistas foram utilizadas para descobrir as categorias de antecipações não reveladas nos documentos e apoiar as conclusões obtidas no trabalho, com pontos de vista dos envolvidos no processo no qual os dados foram coletados. De maneira geral, as entrevistas serviram com o objetivo básico de interagir com as pessoas que tiveram experiências práticas com o problema pesquisado.

As observações podem variar de atividades formais a atividades informais de coletas de dados. Foram retiradas informações diretas ao longo da visita de campo durante as quais foram coletadas outras evidências, como as coletadas em entrevistas (YIN, 2001). As provas observadas, de modo geral, foram úteis para fornecer informações adicionais sobre o tópico que está em estudo.

A observação direta foi utilizada como fonte de análise para comparar e verificar a documentação.

Entre as vantagens de se fazer observação estão: a possibilidade de participar de eventos ou de grupos que, de outro modo, são inacessíveis à investigação científica e a possibilidade de perceber a realidade do ponto de vista de alguém de dentro do estudo de caso.

Além disso, as ações conduzidas pelas empresas construtoras foram analisadas em detalhes, focando-se, entre outros, os aspectos relativos à tecnologia, equipamentos, recursos de informática, gestão de empreendimentos, gestão de projetos, gestão da produção, capacitação de recursos humanos e, principalmente, o estabelecimento de parcerias com outros agentes.

Uma parte da pesquisa de campo referente aos primeiros trabalhos do grupo de estudo de “formação de redes” foi anteriormente desenvolvida através de visitas a obras em São Paulo, com o principal objetivo de verificar como essas empresas realizam o processo construtivo. As documentações encontradas (com informações ou diretrizes do processo construtivo) foram utilizadas como dados para o projeto em proposição. 
Definir uma questão de estudo de caso como fundamento lógico para este, segundo Yin (2001), é provavelmente o mais importante passo a ser considerado.

A partir das características listadas desta obra e para complementação deste estudo foram definidas também questões significativas, algumas delas demonstradas por Javidan (1998). Algumas das questões principais que o estudo de caso buscará responder:

- Quais as empresas que compõem o consórcio ou rede e como são subcontratadas outras empresas que podem participar da mesma?

- Quais as obrigações dos contratantes em relação aos contratados e vice-versa?

- Quais os pontos da cadeia de valor em que a empresa que compõem o consórcio, ou as empresas subcontratadas, particularmente fazem um bom trabalho?

- A empresa responsável por determinado serviço possui uma capacidade, uma competência ou uma competência essencial para a realização do mesmo?

- Essas competências são mais fortes que as competências de outras empresas?

- Que tipo de ligação existe entre as competências essenciais dessas empresas e as vantagens competitivas?

A partir da morfologia definida por Britto (2002a), serão identificados os nós, posições, ligações fluxos da obra. Foram estabelecidos os critérios para definir qual a competência essencial da empresa participante. No final foi sistematizado um método para identificar competências essenciais.

Este projeto fez uma pesquisa descritiva baseada em estudo de caso exploratório em uma obra de grande porte da construção civil. Para Dane (1990), a pesquisa descritiva examina um fenômeno para melhor defini-lo e diferenciá-lo de outro fenômeno. A pesquisa descritiva procura coletar informações e conhecimentos prévios sobre determinado problema a partir de determinada hipótese. A pesquisa descritiva observa, analisa e correlaciona os fatos ou fenômenos sem manipulá-los e pode assumir diversas formas. Esta pesquisa cuja proposta foi descrever as características de determinado fenômeno ou o estabelecimento de relações entre variáveis envolveu o uso de técnicas padronizadas de coleta de dados: entrevistas, observação, análise documental e assumiu, de modo geral, a forma ou delineamento de estudo de caso. $\mathrm{O}$ tipo de pesquisa descritiva usada neste estudo, é de caráter exploratório.

O estudo de caso exploratório restringe-se a buscar maiores informações sobre determinado assunto de estudo, realiza descrições precisas da situação e procura descobrir as relações existentes entre os elementos componentes das mesmas. Por fim, tenta descobrir se o fenômeno em questão realmente existe ou não (CERVO e BERVIAN, 1983; DANE, 1990). 
A unidade de análise foi a obra do metrô na cidade de São Paulo - SP e teve como variável principal as atividades realizadas pelas empresas que dela participam. A unidade de análise e o delineamento da pesquisa serão explicados, com maiores detalhes, em capítulo posterior.

Esta pesquisa propôs abordar conceitos de Competências Essenciais e Redes de Empresas e da Construção Civil para, assim, analisar quais as principais competências que devem se encaixar em determinada rede de construção, com destaque para o trabalho coletivo na organização, coordenar de forma especial as diversas habilidades da produção e integrar as múltiplas correntes de tecnologia. Para isso, foi utilizada a metodologia de sistemas "soft", pois ela parte de um problema não-estruturado e necessita ser contextualizado para permitir a identificação de suas variáveis (PIDD, 1997).

Seguindo a abordagem da metodologia de sistemas desenvolvida por Checkland (1981), foram definidas as sete etapas representadas na figura 2 . A linha que separa os estágios 1, 2, 5, 6 e 7 dos estágios 3 e 4 relaciona-se à divisão do mundo real e do pensamento sistêmico em uma análise lógica. As duas primeiras atividades da figura 2 procuram representar a situação problema e o que nela ocorre. As atividades abaixo da linha são sistematizadas para entender o que ocorre no mundo real. As três últimas atividades demonstram a resolução da problemática por meio da comparação do ambiente real com a análise feita anteriormente. Esta metodologia tenta enfatizar a aprendizagem ao decorrer de seu uso, analisa a vida real, volta às mesmas questões já abordadas em outras atividades e realiza várias iterações no ciclo (PIDD, 1997).

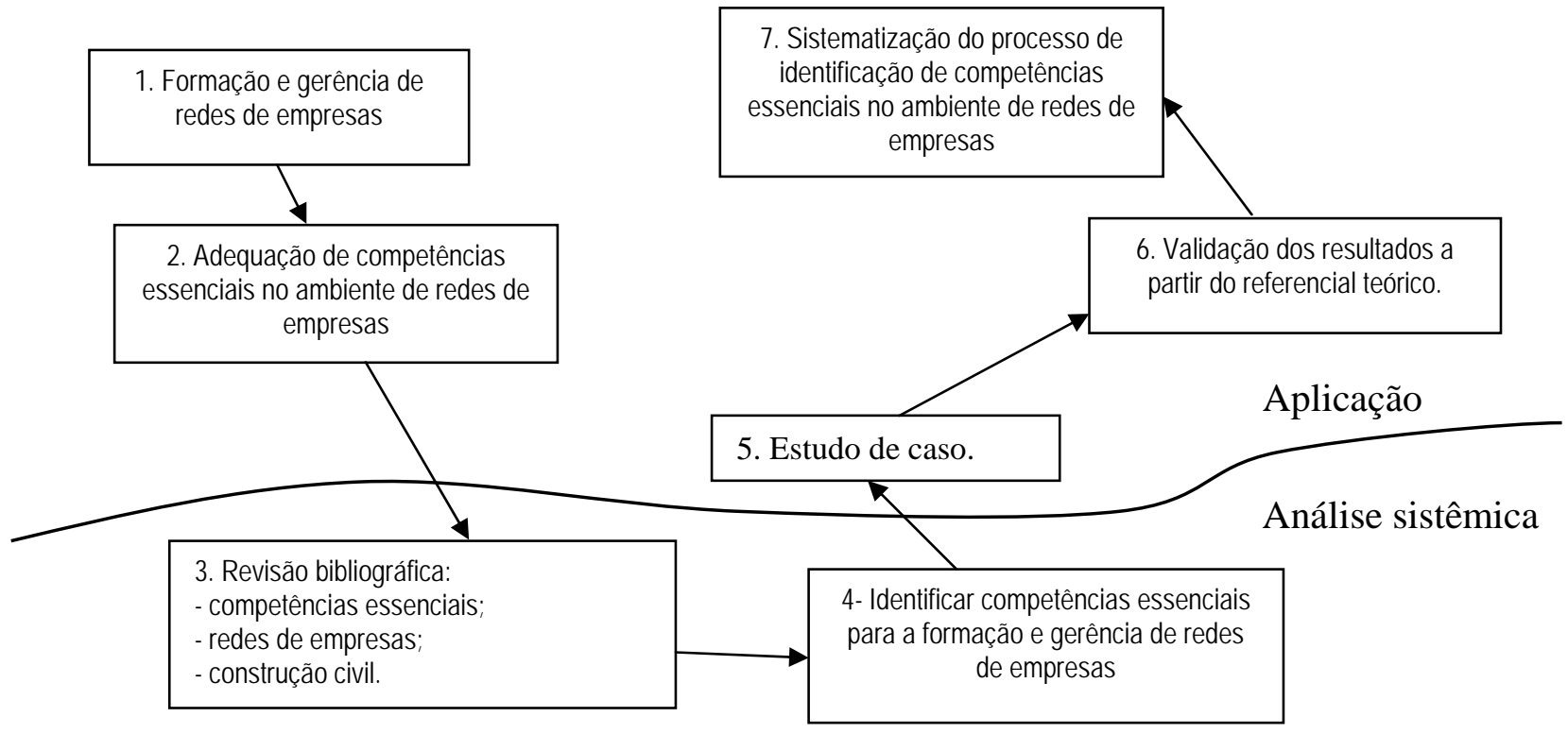

Figura 2 - Etapas da pesquisa 
Para formar e gerenciar redes de empresas (1) é necessária a adequação de competências essenciais no ambiente de redes de empresas (2). Na próxima etapa, no pensamento sistêmico, está elaborada a revisão bibliográfica (3), para a compreensão do estado da arte sobre o tema, das metodologias propostas e os possíveis desdobramentos sobre o escopo e desenvolvimento de pesquisa, compreendendo o processo de formação de redes, como se encaixam as competências essenciais dentro desse conceito e como estas se adaptam às empresas do campo de engenharia civil. Em seguida, identificam-se as competências essenciais para a formação e gerenciamento de redes de empresas (4). A aplicação prática é feita através de um estudo de caso exploratório em obras de construção civil buscando as competências contidas nas empresas participantes para, assim, poder afirmar quais são essenciais para formação da rede e quais poderão trazer benefícios à mesma ou a outras que virão a se formar (5). Avaliam-se os resultados a partir de referencial teórico (6) e, por fim, faz-se a sistematização das competências essenciais em redes de empresas da construção civil.

\subsection{Estrutura do Trabalho}

Este trabalho foi subdividido em sete capítulos. Na introdução são apresentados o contexto, o histórico e a justificativa deste trabalho, inicia-se a discussão do estudo realizado através da descrição do problema, dos objetivos e da estratégia de pesquisa.

No segundo capítulo é apresentada uma revisão bibliográfica no qual se discute o contexto geral de redes de empresas.

No capítulo três são apresentados os fundamentos de competências essenciais; discute-se o conceito e a sistematização através da apresentação de diversas abordagens. Este capítulo procura estabelecer a principal base conceitual sobre o assunto desenvolvido ao longo da pesquisa.

O quarto capítulo trata do envolvimento da construção civil nos contextos de redes e competências essenciais.

O quinto capítulo envolve a apresentação da coleta de dados obtidos no estudo de caso e a sistematização dos resultados obtidos. Neste capítulo estão relatadas as observações do autor para os fenômenos registrados ao longo da pesquisa.

No sexto capítulo, apresentam-se a análise de dados e os resultados obtidos no estudo de caso com os objetivos e hipóteses levantadas na pesquisa. Este capítulo apresenta a sistematização da identificação de competências essenciais.

No sétimo capítulo, estão colocadas as conclusões sobre o trabalho e a apresentação de propostas para futuros trabalhos. 


\section{REDES DE EMPRESAS PRODUTIVAS}

\subsection{Redes de empresas}

Muitas propostas de se organizar para competir têm sido apresentadas como substitutas a formas antigas de se atuar. Surgem então novas perguntas sobre como estas novas formas podem contribuir e ajudar as unidades a serem eficazes. O capítulo destina-se a descrever e discutir os principais conceitos relativos ao processo de formação e desenvolvimento de redes de empresas, as tipologias dessas redes e, por fim, quais as maiores vantagens e oportunidades de negócio que se viabilizam ao se trabalhar desta forma.

As pessoas poderiam ser influenciadas a concluir que empresas deveriam construir sistemas fortes que criam e desenvolvem produto, com a arquitetura do produto apropriada de acordo com o que o cliente precisa e, então, desenvolver uma estratégia de produção consistente com sua competência essencial percebida. Em uma indústria muito estática, esta poderia ser uma aproximação razoável, mas muitas indústrias são bastante dinâmicas de modo a tornar suas competências essenciais e a arquitetura do produto altamente instável. Por exemplo, considere o modelo da indústria de computadores durante as últimas duas décadas articuladas pela Intel. Dos anos 70 aos anos 80, a indústria teve uma forte estrutura vertical com cada competidor que oferece produtos com arquiteturas bastante integrantes. A Figura 3 ilustra um esboço da estrutura das indústrias durante esse período quando a IBM era a empresa claramente dominante. $\mathrm{Na}$ época cada companhia era fundamentalmente vertical. A indústria de computadores foi dominada por empresas de sistemas verticalmente integrados. Com isso a IBM, em todos os aspectos, dominou virtualmente as industrias nesse período. (FINE e WHITNEY, 1996). 


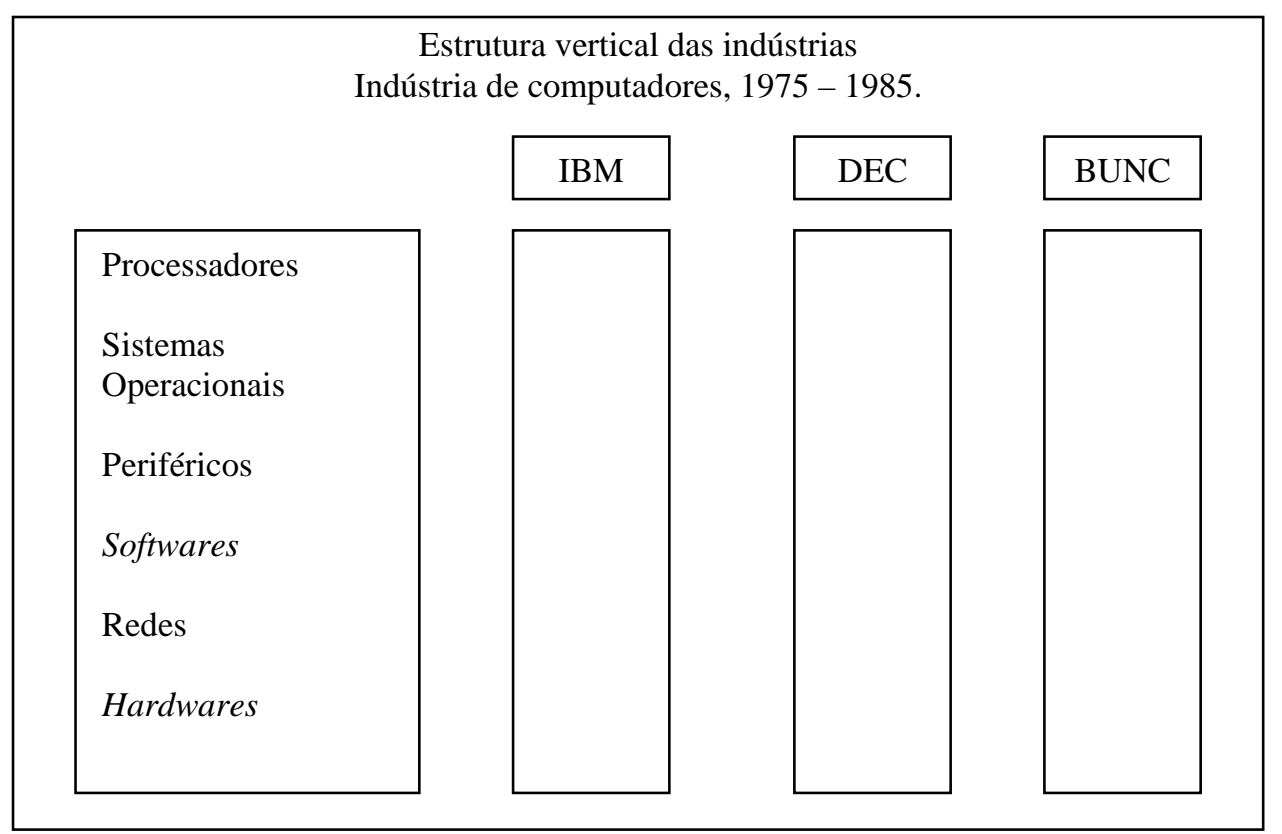

Figura 3 - Estrutura vertical das índustrias (FINE e WHITNEY, 1996).

Embora esta estrutura tenha sobrevivido, durante algum tempo, a IBM constantemente enfrentava a concorrência. A IBM teve que manter as suas competências essenciais em várias tecnologias e, com isso, tornou-se vulnerável a ataques focalizados em cada um dos muitos subsistemas. Para manter sua posição, a IBM precisou manter uma arquitetura relativamente fechada e oferecer os melhores sistemas, de forma que clientes não os trocassem por um competidor com um desempenho melhor em um subconjunto dos subsistemas necessários. Assim, a precariedade da situação para um fornecedor de sistemas se mostrava clara. Então, no final da década de 70, o grupo IBM escolheu abandonar a arquitetura vertical e trocar por uma estrutura horizontal. Passou-se então a haver competição em cada fila da estrutura e, assim, as empresas passam a focar o seu desenvolvimento apenas em suas competências essenciais como é mostrado na figura 4 (FINE e WHITNEY, 1996). 


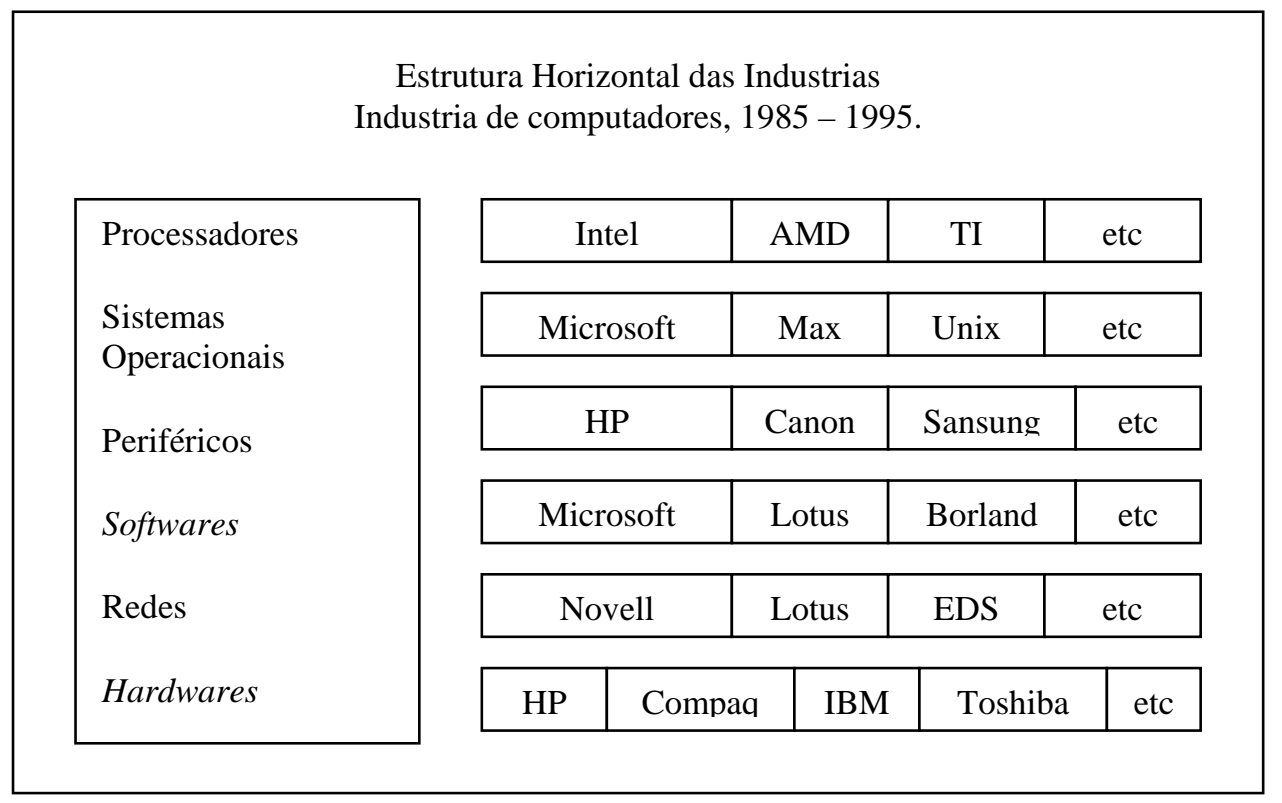

Figura 4 - Estrutura horizontal das índustrias (FINE e WHITNEY, 1996).

Com o passar do tempo, a grande empresa vertical modificou-se em pequenas empresas de menor porte. As empresas então se desintegraram em outras pequenas empresas, como decorrência natural do processo de evolução das organizações.

Essa descentralização fez com que crescesse a necessidade de maior coordenação e integração entre as empresas, alcançadas através da aplicação dos conceitos de redes (GALBRAITH, 1995). O próprio avanço tecnológico contribuiu para uma transição do paradigma de produção em massa (integração vertical) para um paradigma de produção flexível (desintegração vertical), que estabeleceu a importância do relacionamento com outras empresas (CARDOSO et al, 2000a).

Pode-se confirmar que o conjunto das características das empresas de hoje tem como fatores predominantes aspectos relacionados à cooperação, às parcerias, como as formas de sistemas de cooperação em rede entre produtores, fornecedores, usuários, consumidores e, até mesmo, empresas concorrentes.

Alguns dos processos de organização horizontal resultam de pressões atuais do ambiente. Essas forças são descritas por Galbraith (1995):

- A evolução da economia global e o atual aumento das pressões competitivas;

- As pressões de velocidade que trazem a redução de tempos e de prazos;

- A melhoria dos processos organizacionais;

- O poder do cliente que requer melhoria para suprir todas as suas necessidades;

- O avanço tecnológico que ajuda na ligação de diferentes áreas da organização; 
- A rápida criação de produtos com utilização de diversas competências que precisam ser administradas através de múltiplas unidades de negócios. (PRAHALAD e HAMEL, 1990 apud GALBRAITH, 1995).

A combinação destas forças apresentadas por Galbraith (1995) tem ocasionado grande variedade de mudanças organizacionais e esforços para a reestruturação, pois somente assim as empresas conseguem seguir o mercado futuro. O modelo tradicional de organização a cada vez é mais substituído por modelos organizacionais providos de mecanismos para a integração de funções múltiplas.

Atualmente a grande produtividade e competitividade originaram o surgimento de redes de empresas, uma forma de organização do processo produtivo que tem sido cada vez mais utilizada (GALBRAITH, 1995). Aparecem então diferentes autores que apresentam diferentes definições para rede de empresas.

Britto (2002b) define rede de empresas como “arranjos institucionais que possibilitam uma organização eficiente de atividades econômicas, através da coordenação de ligações sistemáticas estabelecidas entre empresas independentes”.

Para Cândido (2001), uma rede de empresas é uma estrutura organizacional, do qual participam empresas que, devido a falta de características estrutural e financeira, não podem assegurar as devidas condições de sobrevivência e desenvolvimento. Esta rede pode existir simplesmente para a troca de informações ou para ser envolvida em um processo de atividades conjuntas. Uma rede organizacional se constitui numa associação de curta ou longa duração, entre duas ou mais companhias que tenham interesses comuns. Em uma rede, as empresas cooperam em função de uma necessidade mútua e compartilham habilidades e riscos para atingir um fim comum.

Rede de empresas é o conjunto de empresas de um mesmo ramo com objetivos comuns que se unem para atuar em um determinado mercado. De modo geral, as redes nascem da consolidação sistemática entre empresas e assumem diversas formas (LAUMANN, GALASKIEWICZ e MARSDEN, 1978).

Segundo Brito (2000), existe uma certa confusão entre os conceitos de "empresas em rede" e "redes de empresas". O primeiro deles associa-se a conformações intraorganizacionais que estruturam-se como desdobramento evolutivo da empresa multidivisional, a partir do advento de novas tecnologias de informação-telecomunicação. $\mathrm{O}$ conceito de "redes de empresas” refere-se a arranjos inter-organizacionais baseados em vínculos cooperativos sistemáticos entre empresas formalmente independentes. 
É possível concluir, através destas definições, que as redes de empresas surgem por meio de um agrupamento formal ou informal de empresas autônomas, com o objetivo de realizar atividades comuns, permitindo que elas se concentrem apenas em suas atividades principais. No caso de rede de empresas produtivas serão consideradas apenas integrantes da rede as empresas que atuam no processo de construção, aquelas que atuam diretamente na etapa de produção, onde cada empresa executa uma etapa do processo produtivo. Excluem-se todas as empresas fornecedoras de suprimentos. Porém, no caso da construção civil a empresa que executa a construção pode ser contratada para fornecer material conjuntamente.

\subsection{Tipologias de redes}

As redes de empresas constituem uma forma organizacional passível de ser identificada em diversos tipos de organizações produtivas e inovadoras. Existem algumas características no contexto das redes que formam um ambiente vantajoso na geração das redes de empresas (BALESTRIN, VARGAS e FAYARD, 2003):

- As empresas têm que compartilhar e discutir informações sobre mercados, tecnologias e lucratividade;

- Existe suficiente similaridade entre processo e técnicas das empresas e, assim, cada uma poderá entender e julgar o comportamento das outras;

- Ocorre recompensa financeira similar para empresas e empregados dentro delas;

- Há um alcance de vantagem econômica pela experiência coletiva das empresas, pelo aumento das vendas e pelos ganhos marginais.

Na busca deste ambiente pode-se reconhecer alguns fatores peculiares à formação de redes.

Nassimbeni (1998) identifica três características básicas em uma rede. A primeira delas refere-se ao número de participantes, em que uma rede pode ser formada por duas ou mais empresas. A segunda apresenta a estrutura legal comumente usada , o "contrato relacional". Este contrato pode ser desenvolvido e sustentado apenas pelas empresas que participam da rede. E a terceira característica é a de formar dinâmicas de comunicação e cooperação que são desenvolvidas de forma a adequar, adaptar e sincronizar a atividade de cada parte às atividades de todo o sistema.

As redes também podem ser descritas e classificadas segundo seus graus de formalização, centralização (simétrica ou assimétrica) e mecanismos de cooperação. O termo assimétrica refere-se à rede que tem um agente central e os contratos são feitos quanto aos produtos ou serviços e não quanto ao relacionamento entre as empresas. A rede simétrica tem como 
principal característica o fato de que todos os participantes possuem o mesmo grau de poder de decisão. Os três tipos básicos de rede são: redes sociais onde não há contrato formal, redes burocráticas com o contrato formal e redes proprietárias que formalizam acordos relativos ao direito de propriedade entre os acionistas de empresas (GRANDORI e SODA, 1995).

Laumann, Galaskiewicz e Marsden (1978) generalizam as redes de empresas como um grupo de nós (empresas) ligados por algum tipo de relação social. Britto (2002a), por sua vez propõe organizar os elementos morfológicos comuns a este tipo de estrutura em rede. São eles os nós, posições, ligações e fluxos, que podem ser verificados no quadro 1.

\begin{tabular}{|c|c|}
\hline Elementos Morfológicos Gerais das Redes & Elementos Constitutivos das Redes de empresas \\
\hline Nós & Empresas ou Atividades \\
\hline Posições & Estrutura de Divisão de Trabalho \\
\hline Ligações & Relacionamentos entre Empresas \\
\hline Fluxos & $\begin{array}{c}\text { Fluxos de Bens (tangíveis) e de Informações } \\
\text { (intangíveis) }\end{array}$ \\
\hline
\end{tabular}

Quadro 1 - Elementos estruturais das redes de empresas (BRITTO, 2002a).

Os nós são as unidades básicas da rede de empresa. As posições são associadas à divisão do trabalho, em que cada empresa participante precisa atingir um objetivo. Dentro de cada uma destas posições destaca-se uma competência essencial. As ligações, propriamente ditas, podem caracterizar as redes em estruturas dispersas, cujo número de ligações é bastante limitado, e estruturas saturadas, onde quase todos os nós estão ligados a todos os demais da rede. Para que as redes possam funcionar adequadamente é necessária completa divulgação das informações entre os diversos componentes da rede. O fluxo, elemento que circula pelas ligações, no caso específico de redes de empresas, pode ser de bens tangíveis ou intangíveis (informações) (BRITTO 2002a).

Geralmente as redes possuem uma demanda de mercados tradicionais, apresentando baixa capacidade de reversibilidade entre os parceiros da rede ou então situam-se em um ambiente turbulento com inesperadas variações de demanda que apresentam alto grau de reversibilidade e, assim, uma arquitetura menos estável (BELUSSI e ARCANGELI, 1998).

\subsection{Vantagens de trabalhar em rede}

Atualmente, o aumento da produtividade e o ganho de competitividade, referem-se à reestruturação do processo produtivo com a formação de redes. Devido à existência das burocracias na vida organizacional, poucos deixariam de reconhecer o surgimento dessa nova 
forma de organização. Os autores da Teoria das Organizações apontam, além do modelo vertical hierarquizado das organizações, o surgimento de um novo tipo relação intra e interempresariais mais horizontalizada, mais democrática e participativa, que deve ser estimulada. Segundo Porter (1992), a integração vertical pode ter sido uma estratégia apropriada no passado, mas hoje as empresas precisam construir relações sólidas com outras instituições.

Na economia globalizada, redes de empresas, um número de empresas de um mesmo setor produtivo em que cada qual executa uma pequena parte do processo produtivo, trazem ganhos em eficiência coletiva que, raramente, produtores separados podem atingir (AMATO NETO, 2000).

Para Daboub (2002), empresas em rede dividem riscos de investimentos, reduzem a complexidade do negócio e diminuem custos com gerenciamentos. Uma das maiores vantagens dessa aliança é a empresa ter a oportunidade de poder aprender e crescer com os parceiros.

A cooperação entre empresas pode viabilizar o atendimento de uma série de necessidades das empresas, de difícil obtenção, se as empresas trabalharem isoladamente. Entre estas necessidades, pode ser destacado (AMATO NETO, 2000):

- Combinar competências e utilizar o conhecimento técnico de outras empresas;

- Dividir o ônus de realizar pesquisas tecnológicas;

- Partilhar riscos e custos de explorar novas oportunidades;

- Oferecer uma linha de produtos de qualidade superior e mais diversificada;

- Exercer maior pressão no mercado.

- Fortalecer o poder de compra e obter mais força, para atuar nos mercados internacionais.

Além de especializarem-se apenas em suas atividades fins, essas empresas ainda obtêm vantagens como melhoria da produtividade; redução de custos; poupança de recursos; acesso a novos mercados, novas tecnologias, mão-de-obra e fornecedores; aumento do poder de barganha em compras e comercialização; troca de experiências e maior acesso à informação; melhoria da reputação do setor; maior acesso a instituições e a programas governamentais (SEBRAE, 2004a).

Segundo Nisembaum (2000), uma organização bem estabelecida, no caso uma rede de empresas, pode desenvolver as competências necessárias para fazer com que todos juntos, possam aspirar a busca do sucesso organizacional. 


\subsection{Busca de parceiros}

Geralmente, as empresas não possuem todas as competências necessárias para tirar proveito das oportunidades que o mercado oferece, por isso necessitam firmar alianças, parcerias, estabelecer fusões, atuar em rede etc. Como filosofia, as empresas têm buscado concentrar-se cada vez mais na sua atividade-fim e na busca de parceiros confiáveis para terceirizar as atividades de suporte ou atividade-meio ${ }^{1}$ (LAMPEL, 2001)

Na medida em que existe uma grande diversidade de conceitos e aplicações para o entendimento de redes de empresas, é essencial analisar o papel dos seus diversos agentes. No entanto, isto não é fácil de ser operacionalizado. A análise de uma rede que envolve as características técnicas produtivas das empresas que pertencem a ela e o conjunto de informações técnicas e habilidades tornam-se essencial e pode ser coletada através de algumas das etapas do ciclo de vida para formação de redes proposto por Goranson (1999):

- Identificar oportunidades: identificar, refinar e caracterizar oportunidades de negócio;

- Buscar parceiros: procurar parceiros adequados para atuar nessa oportunidade de negócio;

- Formar: elaborar um estudo empresarial;

- Operar: colocar em funcionamento a rede;

- Dissolver / reconfigurar: fazer melhorias para explorar as oportunidades de negócio.

Para Goranson (1999), após a identificação de oportunidades, deve-se buscar parceiros para a formação da rede. Essa busca baseia-se na identificação de competências essenciais através de critérios como o nível de confiança e os indicadores de negócios. As competências essenciais das empresas devem ser analisadas por meio de outros fatores que vão qualificálas: qualidade, técnica, capacidade e o critério financeiro. Este processo deve ser rápido e barato.

Himes (1995) coloca alguns dos motivos que levam a busca de parcerias:

- Intensificar e resolver problemas rapidamente e com baixo custo;

- Aumentar a segurança e viabilizar qualquer obra gerando fortes incentivos;

- Aprender através das competências dos parceiros;

\footnotetext{
${ }^{1}$ Para Sergio Pinto Martins (2000), a atividade-meio pode ser entendida como a atividade desempenhada pela empresa, que não coincide com os fins principais, essas atividades são subcontratadas por empresas que estão desenvolvendo a atividade-fim. As empresas não podem terceirizar sua atividade-fim, pois com isso elas estão entregando seu próprio serviço para outra empresa realizar.
} 
- Baratear custos para disputa no mercado.

Como visto, entre todas estas fases verificadas por Goranson (1999) o trabalho proposto neste projeto está focado na busca de parceiros.

Existe uma grande variação de métodos para a sua identificação. Um dos métodos para qualificar os parceiros é fazer alianças com terceiros para que a lealdade e a avaliação apareçam com erros e interpretações durante o tempo em que se mantiverem juntos. Outro método é estudar e medir os candidatos através de seu histórico avaliando os critérios desejados. Os dois métodos presumem uma evolução do candidato, porém mesmo desta maneira deve ser feita uma pesquisa exaustiva para uma pré-avaliação dos mesmos. Assim, fica em aberto a melhor maneira de selecionar parceiro (GORANSON, 1999).

\subsection{Considerações finais}

Dentre todas as formas e critérios para a busca de parceiros para uma rede de empresas, a seleção, através das competências essenciais, mostra-se relevante ao longo deste trabalho.

O conceito de competência essencial, definido por Hamel e Prahalad (1995), baseado na idéia de que todas as empresas têm competências essenciais, nas quais devem concentrar-se para obter um retorno máximo, pode trazer uma série de implicações para as empresas no atual ambiente organizacional.

Nesse novo contexto o posicionamento das empresas parte da idéia de que o mais importante fator na estruturação de uma rede é a competência; a participação e a posição de cada empresa é função de suas competências essenciais. A posição na rede e a forma pela qual as competências são administradas, por sua vez, vão influenciar as estratégias competitivas (FLEURY, 2003). 


\section{COMPETÊNCIAS ESSENCIAIS}

Este capítulo demonstra como a competência essencial pode se tornar o principal requisito de uma empresa para a sua integração como parceira para atuar em rede de empresas produtivas. Como dito, este requisito está relacionado com a busca de parceiros do ciclo de vida de uma rede.

\subsection{Hierarquia de competências essenciais}

Comumente a palavra competência está associada à aptidão, habilidade, saber e conhecimento. Estas qualidades, na maioria das vezes, estão associadas a uma pessoa. Por outro lado, nas empresas, a palavra competência está ligada à função de gerenciamento e inclui planejar, delegar, treinar, avaliar o desempenho e reconhecer realizações gerenciais. É justo acreditar que, de qualquer maneira, todas estas competências estão correlacionadas. Porém, o significado de competência refere-se à competência empresarial como um conjunto de habilidades e tecnologias utilizadas pela empresa para definição de solução de problemas e conseqüentes implementação de alternativas de crescimento (HAMEL e PRAHALAD, 1995).

O significado de competência, antes sinônimo de "habilidade humana”, agora é associado, também, à inovação, ao resultado e à eficiência, atribuindo maior exigência e maior complexidade às funções de uma empresa. Mais que isto, a posse de uma competência escassa em relação à demanda, pode proporcionar ganhos superiores à empresa que o possuir e explorar adequadamente. A avaliação deste fator estratégico revela-se um grande passo para a transformação de competências em competências essenciais, com vistas à obtenção de vantagens competitivas. “Competências essenciais” têm se tornado uma nomenclatura padrão em negócios e sua repercussão poderá garantir o resultado em alguns programas de reestruturação em empresas.

Diferentes autores consideram as competências essenciais em diferentes níveis da organização. Autores especializados em recursos humanos consideram as competências em um nível individual e outros consideram a competência através da empresa como um todo (BAKER et al., 1997). 
De acordo com Walsh e Linton (2001), na literatura sobre competências essenciais há diversas definições a respeito de recursos, capacidades, competências e competência essencial. Autores como Javidan (1998), Hamel e Prahalad (1990), caracterizam separadamente estas definições.

Para Terhaag et al. (1996), as competências estão localizadas no campo de interação entre tarefas e habilidades. A idéia de competência responde às perguntas, “O que eu posso fazer?” e “O que eu devo fazer?” (figura 5). Tendo em vista que esta empresa possui as habilidades e, para estas habilidades, todos os recursos requeridos para o desenvolvimento das mesmas, pode-se dizer que a empresa possui uma competência.

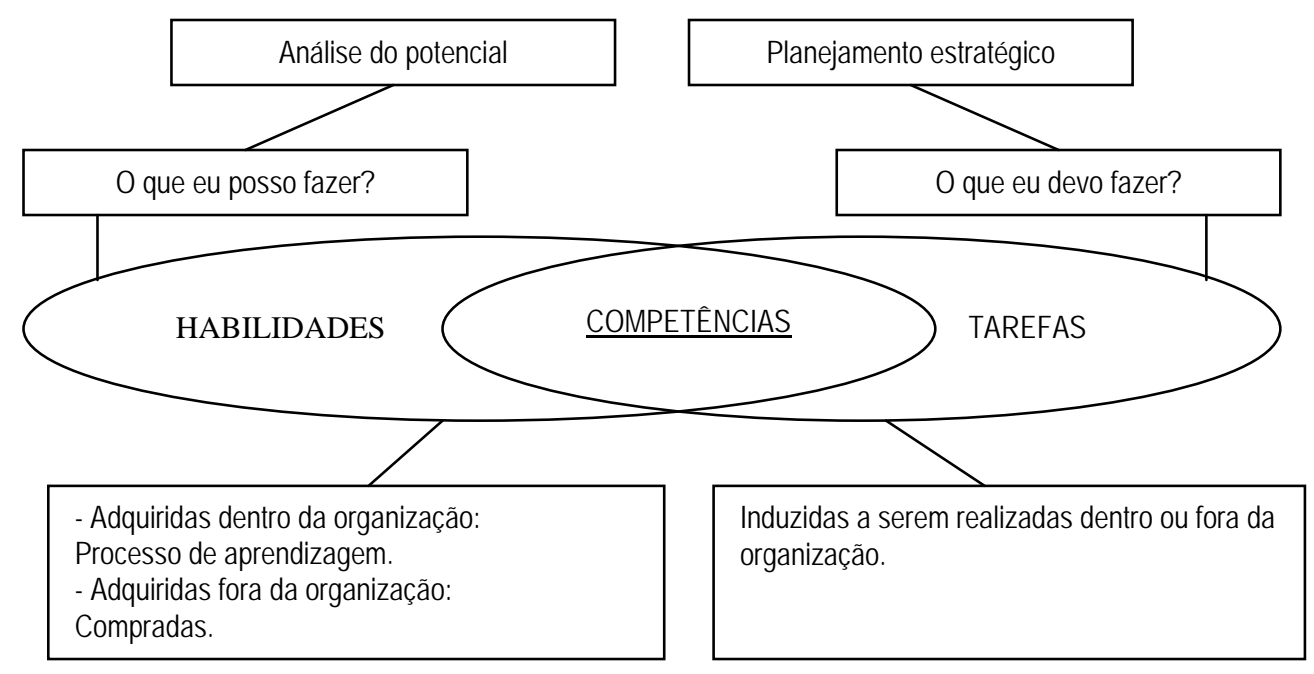

Figura 5 - Competências, relação entre habilidades e tarefas (TERHAAG et al., 1996).

Para Baker et al. (1997) há quatro tipos de competências. A “Competência estratégica” existe quando a empresa possui um poder de adequação entre a estratégia de negócio e o ambiente competitivo externo. Neste nível de competência, a empresa é considerada como um todo. A “Competência diferencial” existe quando a empresa possui um grupo de tecnologias e atividades que fornecem, à mesma, uma vantagem competitiva e está, portanto, relacionada ao desenvolvimento de novos produtos. A “Competência funcional” existe quando a empresa possui um poder de adequação de suas prioridades competitivas às suas resistências em uma função particular como produção, marketing etc. A “Competência individual” existe quando a empresa possui um conjunto de habilidades e de conhecimentos para um trabalho específico. São as competências de quem executa o processo.

Javidan (1998) representa a hierarquia de competências de uma organização de acordo com a figura 6. 

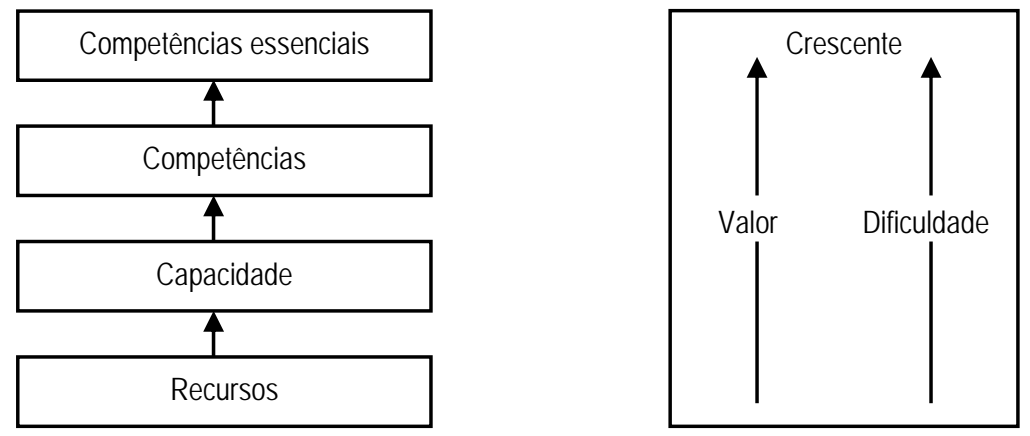

Figura 6 - A hierarquia de competências (JAVIDAN, 1998)

O recurso possui uma grande gama de significados. Para Hafeeza, Zhanga, e Malak (2002) “Recurso” pode incluir recursos físicos (por exemplo, matérias-primas, equipamento, dom financeiro etc.) e recursos humanos (por exemplo, engenheiros, administradores etc.), ou como “entidades tangíveis” (BANERJEE, 2003).

A definição de capacidades usualmente é considerada como parte integrante de recursos. “Capacidade” não faz parte de recurso. As capacidades são os resultados de desenvolvimento de recurso. As capacidades utilizam recursos e, então, é uma entidade mais dinâmica e complexa e deve ser tratada independente de recursos. A união dos recursos é a base das competências (HAFEEZA, ZHANGA e MALAK 2002). A capacidade se refere à habilidade de uma organização em explorar os recursos (JAVIDAN, 1998).

Major, Asch e Cordey-Hayes (2001) argumentam que os recursos de empresas são as condições primárias pelas quais as empresas podem formular, moldar suas estratégias. “Recursos” são, em princípio, igualmente acessíveis a todas as empresas. Porém, os recursos são específicos internos, e podem ser caracterizados por custos ou qualidade. As capacidades provêm do modo como os recursos são definidos para sustentar o desenvolvimento de produtos. De certo modo, isso ajuda uma empresa a alcançar suas metas, porém as capacidades não são suficientes para trazer outros benefícios para as empresas, como vantagens competitivas.

Para o próximo nível da hierarquia, as competências são capacidades que possuem as características que dão condições para as empresas alcançarem suas metas.

Major, Asch e Cordey-Hayes (2001) sustentam a idéia que competências sejam a aplicação de recurso, integração de esforço e desenvolvimento de sistemas e de processos para a administração da produção.

O termo “competência” é utilizado para descrever os recursos, qualificações, habilidades, ou conhecimento, necessários para executar certas tarefas. “Competência” é o conhecimento necessário, como habilidades, e qualificações usadas efetivamente em um processo ou 
atividades. A competência está relacionada às tarefas que são executadas ou administradas por uma empresa. Esse termo ou qualificação demonstra habilidades e conhecimento, condições prévias para execução de uma tarefa (RITTER e GEMÜNDEN 2003). “Competência” é a coordenação e a integração das capacidades. (JAVIDAN, 1998).

No topo da hierarquia estão as competências essenciais, resultado da interação entre diferentes competências (JAVIDAN, 1998).

Para Hamel e Prahalad (1995), entre todas as competências que existem na empresa, algumas delas podem ser consideradas mais importantes por trazerem benefícios e prosperidade para a corporação em longo prazo. Essas competências podem ser consideradas essenciais e há três testes de verificação: o valor percebido pelo cliente, a diferenciação entre concorrentes e a capacidade de expansão .

O "Valor percebido pelo cliente” ocorre quando uma competência essencial deve agregar a percepção de valor ao cliente. São habilidades que oferecem benefícios fundamentais aos clientes predominantes em relação às outras competências. Isto não implica que esta competência seja visível aos olhos do cliente, pois para o cliente apenas o beneficio é visível. O cliente torna-se o juiz deste assunto, se ele não perceber o valor do produto ou serviço que estão lhe oferecendo, não ficará para ele o diferencial e, então, não poderemos contar com sua fidelidade.

A “Diferenciação entre concorrentes” ocorre quando uma competência essencial de uma empresa deve ser difícil de ser copiada pelas demais. O intuito é que esta competência seja um diferencial da empresa para com seus concorrentes.

A “Capacidade de expansão” ocorre quando a competência essencial deve contribuir para aumentar a oferta de valor em produtos existentes ou habilitar novas oportunidades.

“Competência essencial” é um conjunto de habilidades e tecnologias, e não uma única habilidade e tecnologia isolada. A competência essencial permite a uma empresa oferecer um novo benefício aos clientes, pois não é um único motivo ou razão que leva o cliente a uma determinada empresa. Alguns clientes são atraídos pelos preços, outros pela localização, rapidez na entrega das mercadorias, condições de venda, outros pela qualidade. "Competência essencial” é toda atividade desempenhada no processo produtivo dentro da empresa, que agrega valor ao produto ou serviço ao qual se aplica (HAMEL e PRAHALAD, 1995).

No entanto, competência essencial é um termo de difícil compreensão por ser intangível aos empresários responsáveis por seu desenvolvimento, invisível aos observadores externos e difícil de ser analisada (PETTS, 1997). 
Tampoe apud Torkkeli e Tuominen (2002) também listam as características que as competências essenciais devem possuir : a competência deve ser essencial à sobrevivência da corporação, invisível aos competidores e difícil de ser imitada, uma combinação de habilidades, recursos e processos; essencial para o desenvolvimento de produtos essenciais e, conseqüentemente, de produtos finais, essencial para implementação de estratégias da corporação e essencial às decisões estratégicas.

Alguns dos exemplos de competência essenciais são a Sony com competências em miniaturização; a Motorola, com a comunicação sem fio; a Toshiba com a competência em fabricação em telas planas, dentre outros (HAMEL E PRAHALAD, 1995). Para Rao (2002), não são só as empresas que possuem competência. O autor também expande o conceito de competência para nação (país). O Japão, entre outras coisas, tem como competência essencial a integração entre a engenharia mecânica e a elétrica, a produção enxuta e gerenciamento de qualidade. Por outro lado, os Estados Unidos têm como competência essencial suas avançadas universidades, materiais espaciais, materiais bélicos etc..

Hamel e Heene (1994) definiram três níveis de abstração para competências dentro de uma empresa. A Meta Competência Essencial representa o mais alto nível de abstração para uma competência (o que faz uma empresa ser reconhecida). A Competência Essencial é considerada uma agregação de habilidades constituintes; As Habilidades Constituintes são as capacidades e competências básicas de uma empresa, que podem constituir uma competência essencial da mesma.

O nível mais alto, “meta competência essencial”, pode ser relacionado à competência essencial gerada pela rede de empresas formadas pelos componentes A, B e C que possuem suas competências em particular. No nível mais baixo da figura estão representadas as habilidades constituintes de uma empresa, elas formam a competência essencial B. A figura 7 apresenta esquematicamente os três níveis: 


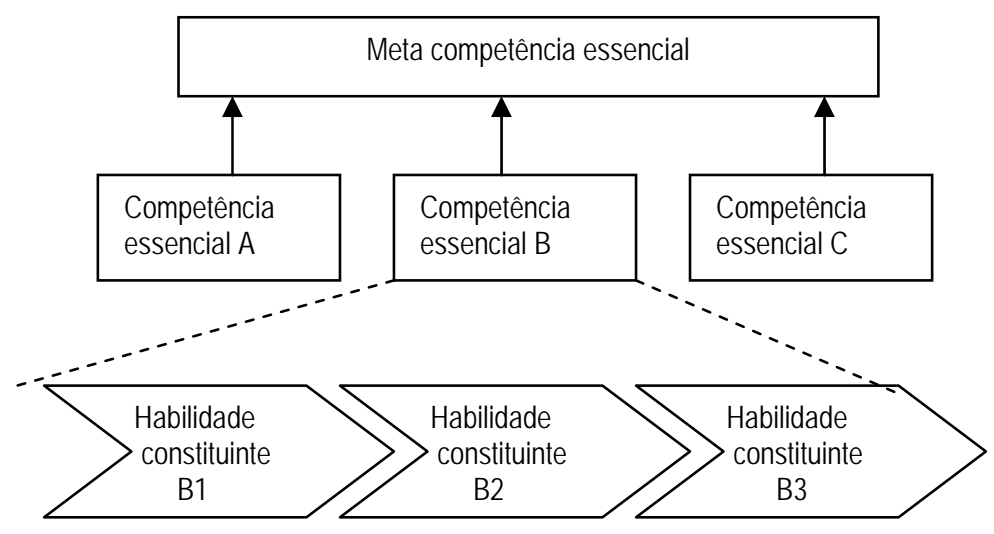

Figura 7 - Níveis de abstração de competências essenciais (HAMEL e HEENE, 1994).

Para o sucesso na identificação de competências, Javidan (1998) propõe a realização de um workshop com objetivo de explicar os conceitos e suas aplicações. Javidan (1998) aponta oito perguntas que devem ser feitas, para esta identificação:

1- Quais são os pontos da cadeia de valor nos quais a empresa particularmente faz um bom trabalho?

- A primeira pergunta esclarece o interesse de cada empresa, suas capacidade e implicações.

2- A empresa possui uma capacidade, uma competência ou uma competência essencial?

- Esta pergunta ajuda a entender os valores que podem ser acrescentados como as competências da empresa interessada.

3- Estas competências são mais fortes que as competências de outras empresas?

- Ligar as competências com as vantagens competitivas que a união desta empresa a rede pode trazer.

4- Que tipo de ligação existe entre as competências essenciais e as vantagens competitivas?

- Esta é uma importante questão, pois estes dois conceitos não são necessariamente a mesma coisa. Nem sempre as competências são vantagens competitivas e nem sempre uma vantagem competitiva é uma competência.

5- Como é a estabilidade destas vantagens competitivas?

- Muitas das vantagens competitivas não duram muito tempo. Vantagens competitivas pressionam a concorrência a dar resposta rápida. A empresa precisa estar sempre preparada ao mercado dinâmico.

6- Quais as mudanças-chave que devem ser feitas na empresa? 
- Analisa quais mudanças têm que ser feitas para que esta atue no mercado dinâmico.

7- Feita as mudanças na empresa, (a) qual competência é obsoleta ou irrelevante? (b) quais competências devem ser mantidas ou melhoradas? (c) Como podemos alavancar nossos recursos, capacidades e competências? (d) Quais são as novas competências que devem ser desenvolvidas?

- Este grupo de quatro perguntas é planejado para encorajar uma estratégia e uma discussão a respeito das competências e capacidades.

8- Onde a empresa deve se encaixar?

- Este estágio está ligado ao planejamento estratégico.

Deve-se tomar cuidado pois, muitas vezes, uma competência pode ser confundida com o seu produto final, o qual pode ser resultado de uma competência. “Competência” não pode ser confundida com o objeto de sua aplicação. Uma grande preocupação neste contexto é esclarecer as diferenças entre competências e produto final. Considerando-se três diferentes termos, competências, processo e produto final, é possível chegar a uma definição clara sobre esta diferença. Um produto final é uma saída de um processo. Já um processo precisa de uma competência essencial para ser desenvolvido (TERHAAG et al., 1996) ${ }^{2}$.

As competências também não são específicas de produtos e contribuem para a competitividade de uma gama de produtos ou serviços. Assim, as competências essenciais transcendem um produto ou serviço específico.

A duração das competências essenciais também é maior do que a de qualquer produto ou serviço somente. O produto final, devido ao mercado dinâmico, sofre mudanças mais rápidas que os processos, conseqüentemente sofre mudanças muito mais rápidas que as competências. O desenvolvimento das competências requer muito mais tempo que a do produto final devido ao seu grande tempo de processo de aprendizagem (TERHAAG et al., 1996). Assim, competência essencial não é um ativo no sentido contábil da palavra pois, ao contrário dos ativos, as competências não sofrem desgastes. Geralmente, quanto mais usada, mais valiosa e aprimorada ela se torna.

Uma competência essencial é uma fonte de vantagem competitiva e um fator crítico de sucesso. Entretanto, a recíproca não é verdadeira, pois não se pode considerar, por exemplo, infra-estrutura, localização e mão-de-obra barata como competência essencial. O que não

\footnotetext{
${ }^{2}$ Esta distinção entre competências essenciais e produto final torna -se esclarecedora para o tema deste trabalho uma vez que o escopo deste projeto está relacionado a redes produtivas e não redes de suprimentos. Os componentes da rede não vão ser medidos segundo seus produtos finais e sim quanto a suas competências essenciais.
} 
significa que essas vantagens não sejam importantes para a empresa (PRAHALAD, 1995 e PETTS, 1997).

Uma comparação ilustrativa é proposta por Prahalad e Hamel (1995, p.297): “Uma empresa diversificada é similar a uma grande árvore. O tronco e os maiores galhos são os produtos essenciais, as ramificações menores são as unidades de negócios; as folhas, flores e frutos são os produtos finais. As competências essenciais formam o sistema de raízes que provê nutrição, suporte e estabilidade”(figura 8). As competências essenciais situam-se na raiz processo crescimento e de criação de novas oportunidades de negócios. Um produto essencial nada mais é do que uma parte, componente ou subunidade, muito importante de um produto final o qual, na maioria das vezes, não é visto pelo consumidor final, fator para dificultar a imitação por parte da concorrência e transformar cada vez mais uma competência em competência essencial.

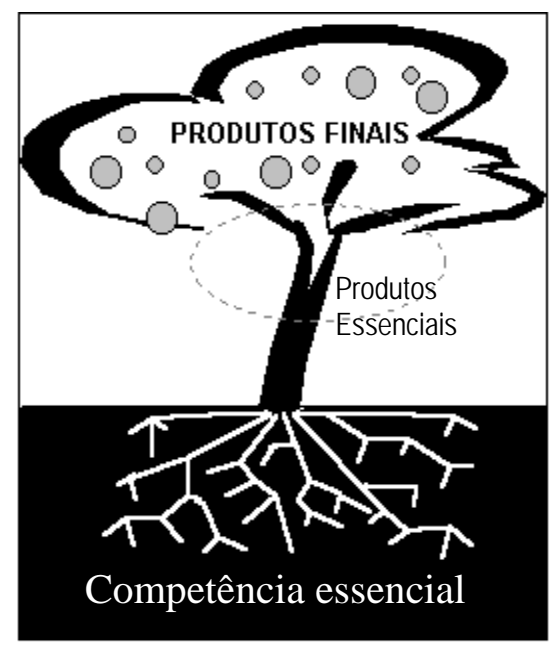

Figura 8 - As raízes da competitividade (WILK, 1999).

Bogner, Thomas e McGee (1999) completam a ilustração de Prahalad e Hamel (1995) argumentando que várias competências essenciais desenvolvem vários produtos essenciais e estes vários produtos finais (figura 9).

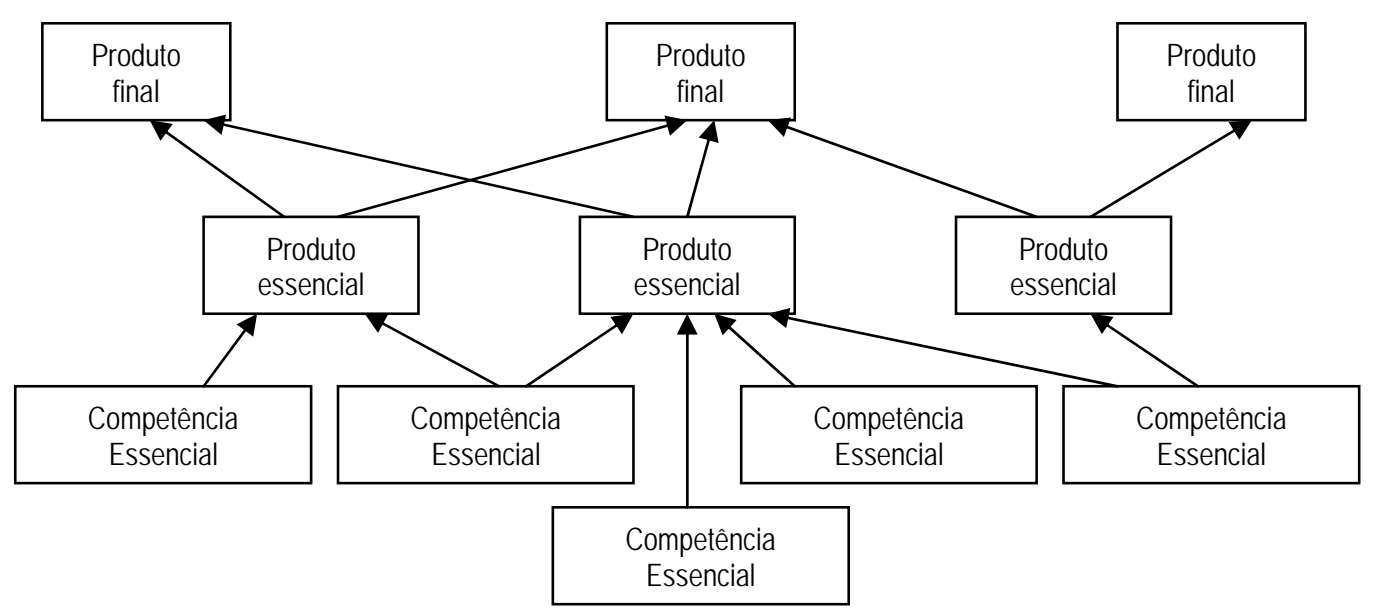


Figura 9 - Reunião e distribuição das competências essenciais (BOGNER , THOMAS e McGEE ,1999).

Por mais que as ligações entre as competências essenciais e o mercado não sejam diretas, as competências essenciais são as características que sustentam a criação de produtos, tecnologias e processos essenciais que, por fim, geram os produtos que são vendidos no mercado (LAMPEL, 2001).

A proposta de Hamel e Prahalad (1995) é que ao invés de concentrar nas condições do setor, os estrategistas deveriam concentrar-se nas competências essenciais de suas empresas e utilizar as habilidades, os processos e as tecnologias para criar vantagem competitiva sustentável em sua cadeia de valor. Os dirigentes e demais tomadores de decisão que não conseguirem assumir a responsabilidade pelo desenvolvimento e estímulo das competências essenciais estarão atrasando o futuro das organizações. É muito provável que as empresas que não têm esse ponto de vista, sejam dominadas nos mercados futuros. Além disso, Harvey e Lusch (1997) propõem que essas competências deverão ser bem protegidas e seguradas a fim de se manter a empresa.

Forbes (1991) salienta que as empresas usam as competências essenciais para reavaliar suas estratégias. Para Gorman e Thomas (1997) a base da competitividade está nas competências essenciais e quando utilizadas como estratégia da empresa, demonstram o crescimento e desenvolvimento de suas atividades.

Prahalad (1998) explica que existe um processo para desenvolver competências essenciais. A primeira pergunta pode ser: “Como será o mundo daqui a dez anos?”. Dados o plano e as forças propulsoras da descontinuidade no mercado - estilos de vida, estilos de trabalho, demografia, distribuição de renda, novas tecnologias, "O que podemos esperar que o mundo seja daqui a dez anos?”. Se esse é o futuro que queremos construir, “Quais são as competências que não possuímos e precisamos adquirir para chegar a ele e como fazer isso?”.

\subsection{Considerações finais}

A hierarquia das competências essenciais encaminha o trabalho a uma sistematização de identificação das mesmas para a formação de redes de empresas. Por fim, a identificação de competências pode se firmar na busca pelos benefícios esperados por uma rede de empresas. Isso deve acontecer, também, quando os objetivos perseguidos já não se cumprem por intermédio da rede e quando ocorrem mudanças no ambiente empresarial que comprometem a rede como estrutura organizacional. Assim, entende-se que a identificação de competências 
essenciais é necessária para a manutenção da competitividade das empresas por meio do desenvolvimento e suas aplicações no processo produtivo em forma de rede. 


\section{O SETOR DA CONSTRUÇÃO CIVIL}

Este capítulo tem como objetivo apresentar uma revisão bibliográfica sobre o processo de execução de obras de construção civil. Será discutida a adequação de redes ao contexto da construção. Serão apresentadas e discutidas as relações entre empresas de construção para, assim, esclarecer os objetivos e a contribuição destas relações para a melhoria e geração de planos de produção no setor. Por fim será apresentada uma proposta de análise sobre redes de precedência, como método complementar destinado a ajudar no processo de identificação das competências.

\subsection{O processo de execução de obras na construção civil}

A indústria da construção exerce importante papel na economia do país dando suporte a outras atividades econômicas através da construção da infra-estrutura necessária para elas. Ela também diferencia das demais indústrias juntamente com as indústrias de fabricação de equipamentos pesados, pois se caracteriza pelo deslocamento dos fatores de produção até o produto, sendo que este ocupa posição fixa. Os sistemas para produção com posição fixa se caracterizam por trabalharem sob encomenda, com projeto específico, baixo volume de produção e, conseqüente, baixa padronização do produto (CASAROTTO, 2002).

SEBRAE (2000) classifica o setor da construção civil com uma atividade de serviço, pois uma obra pode ser realizada por diversas empresas, responsabilizadas por partes específicas de etapas construtivas. Em um edifício, por exemplo, a instalação elétrica, a hidráulica ou a alvenaria são partes de uma obra, mas não são insumos; o material elétrico e as peças sanitárias são os insumos das instalações. Isto significa que diferentes empresas podem ser contratadas para prestar serviços e adicionar valor ao produto (SEBRAE, 2000).

A indústria da construção possui duas características básicas. A primeira é que a maioria do esforço produtivo é desenvolvido em um único local, um canteiro de obras e a segunda é que há um grande número de participantes no processo produtivo (SOIBELMAN e CALDAS, 2000). Assim, o empreendimento de construção pode reunir profissionais que nunca atuaram em conjunto e, então, aparecer uma complexidade de atuações representada pelos papéis a 
serem desempenhados por cada empresa envolvida. Os trabalhos geram interfaces, criam interferências executivas e, assim, são organizados em formas de contratos formais e informais exigindo de todos muito esforço e colaboração.

Em uma obra, ao analisar os condicionantes setoriais que estão por trás das relações das construtoras com seus fornecedores e das potencialidades e limitações da formação de parcerias, o que chama atenção é a quantidade e a variedade dos agentes envolvidos. Em um empreendimento típico de promoção e construção, pode-se contabilizar a participação dos empreendedores/incorporadores, de agentes financeiros, das construtoras, dos fornecedores de materiais e componentes, de serviços subempreitados de obra e dos serviços de planejamento e de projeto. Todos com significativas interferências e responsabilidades (FABRÍCIO, SILVA e MELHADO, 1999).

Os participantes da realização de uma obra, que deveriam colaborar entre si, geralmente realizam um trabalho independente. As relações entre os membros da equipe podem ser descritas como conflituosas e não-cooperativas (GRILO e MELHADO, 2003a).

Percebe-se, então, a necessidade de formalização de um processo desenvolvimento de uma rede de empresa de construção porém, normalmente, isto não é conduzido de forma a explorar todas as suas potencialidades. Essa situação parece agravar-se ainda mais em pequenas e médias empresas de construção, geralmente conhecidas por trabalharem com restrições de recursos ou com uma carga de trabalho excedente para sua capacidade (BERNARDES e FORMOSO, 2000).

Esse processo não é visto por quem gerencia a obra e, conseqüentemente, por quem participa do processo, como uma rede de empresas que cooperam para um fim comum.

De acordo com Grilo e Melhado (2003b), na construção civil, inúmeros benefícios podem ser alcançados por meio de novas formas de relações entre os agentes do processo de produção e do incentivo à cooperação entre as empresas: maior segurança nos canteiros, consonância com o orçamento e o cronograma, redução das reivindicações e melhoria da imagem pública das organizações.

Uma das características dos sistemas produtivos da construção é a configuração do processo construtivo de acordo com o modelo de transformações segundo o qual o que acontece em um sistema de produção genericamente envolve a entrada de recursos, a conversão destes e a geração de saídas do processo de acordo com a figura 10. No modelo de conversões apresentado na Figura 10, um processo de produção é dividido em sub processos. O produto, saída do processo, alcança a maior otimização possível através do somatório de todas as melhorias geradas isoladamente em cada sub processo. A melhoria dos subprocessos 
é comumente baseada na adoção de tecnologias e na avaliação de desempenho, monitorada através de índices de produtividade determinados especificamente para cada operação produtiva (MACHADO e HEINECK, 2003).

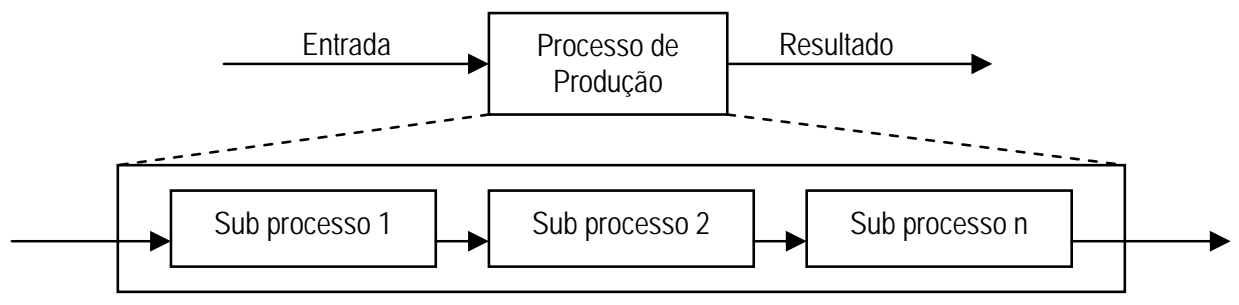

Figura 10 - O modelo de transformações (MACHADO e HEINECK, 2003).

Os diversos subprocessos ou subsistemas (fundação, estruturas etc.) do processo de produção são realizados por uma diversidade de empresas que são integradas pela própria empresa "principal”, ou pelas empresas fornecedoras dos subsistemas. A construtora “principal” passa a funcionar como compradora de subsistemas. Este processo pode ser denominado subcontratação. Existem diversas empresas fornecedoras de diversos subsistemas; é essencial que as participantes do processo de produção detenham um determinado nível de excelência (CARDOSO et al, 2000b). A subcontratação de empresas especializadas para realizar um determinado serviço ocasiona diminuição de custos e, há algum tempo, tem sido utilizada por várias empresas dentro do processo construtivo (CARDOSO et al, 2000).

Para Serra (2001), os processos produtivos se organizam através de relacionamento de subempreitada entre contratantes e contratados, comumente denominado subcontratação ou terceirização.

O processo de subcontratação é uma forma de relação entre empresas. O método consiste de um acordo entre duas partes, a empresa contratante e a empresa subcontratada. A empresa contratante atribui a uma ou várias empresas a produção de partes, componentes, serviços técnicos necessários para fabricação de seu produto final. Este método possibilita às empresas atingir uma alta taxa de eficiência, através do uso racional de sua capacidade instalada e uma melhor utilização de outros recursos disponíveis. Há, assim, a divisão do trabalho dentro do setor industrial e as subcontratadas tornam-se crescentemente especializadas em um ou mais campos tecnológicos (SEBRAE, 2004b).

Segundo Serra (2001, p.191), as fases do processo de gestão dos subempreiteiros podem ser resumidamente descritas: 
- Seleção: processo sistematizado de planejamento, convocação e análise das ofertas de serviço dos subempreiteiros para a definição daquela mais indicada para execução.

- Avaliação: definição dos parâmetros e critérios de análise das ofertas de serviço encaminhadas e do desempenho dos subempreiteiros;

- Formalização da contratação: definição de regras e cláusulas a serem seguidas durante a elaboração do contrato entre as partes;

- Organização: diretrizes de gerenciamento dos subempreiteiros durante sua permanência no canteiro de obras e de avaliação da prestação do serviço de assistência técnica.

No entanto, um fator como a competência essencial, que qualifica uma empresa para determinado serviço, normalmente, diretamente não faz parte da análise. A decisão do que deve ou não ser terceirizado poderá vir através do conhecimento da empresa e de suas competências essenciais. A escolha de quais empresas serão subcontratadas pode ser confirmada com a análise das competências essenciais de cada empresa.

Um nível mínimo de qualidade também pode influenciar a decisão da escolha de competências em uma construção. Segundo Fabrício e Melhado (1998), um ponto a ser considerado é o aumento da exigência dos clientes em relação à qualidade que ocorre em todos os setores e afeta o setor da construção. Códigos de defesa do consumidor aumentam a conscientização da sociedade quanto às exigências em relação à qualidade dos produtos. Na construção, propriamente, a qualidade é valorizada como um elemento importante de competitividade; e os impactos dessa maior exigência podem ser percebidos pela proliferação de empresas que buscam implantar programas de gestão da qualidade e produtividade e a obtenção de certificados de garantia da qualidade.

Em obras de grande porte ou obras públicas, a parte contratante utiliza os processos de licitação. As empresas interessadas em participar destas concorrências públicas devem ser cadastradas, apresentar documentos comprobatórios da habilitação jurídica; qualificação técnica; qualificação econômico-financeira; regularidade fiscal. Normalmente, na execução de obras, aplica-se a licitação por "menor preço”, alternativa nem sempre vantajosa. Existe alguns outros tipos de licitação como "melhor técnica” ou "técnica e preço", embora as propostas sejam selecionadas, na prática, com base no "menor preço” (Lei 8.666/93) (GRILO E MELHADO, 2002). 
Tanto para uma licitação que exige qualidade de serviço “melhor técnica” ou custo “melhor preço”, na pré-qualificação dos licitantes pode ser considerada a identificação de competências essenciais.

Por isso, a identificação de competências essenciais necessárias torna-se plausível e pode seguir o mesmo andamento do relacionamento de subcontratação. A escolha dos parceiros obedece o cronograma da obra, onde é montada a programação dos processos e são definidos os momentos e em que quantidades os processos deverão ser feitos, o que contribui para a programação e organização das atividades. A escolha de parceiros é realizada e preparada a proposta para execução da obra.

O cronograma de uma obra diz respeito a todas as atividades em uma única escala de tempo e deve conter as seguintes informações: atividades identificadas; responsáveis pela atividade (possíveis competências); duração esperada para cada atividade. A identificação de uma equipe é feita com base em estudos prévios, de acordo com as especialidades necessárias, promovendo uma divisão e nomeando os responsáveis por cada item a ser executado com a definição do tempo necessário para cada tarefa. São analisadas todas as partes do empreendimento, detalhado todos os métodos, materiais, equipamentos e as práticas construtivas de cada participante (MACHADO, 2003).

Além do serviço especializado incluem-se as avaliações das assimilações durante a implementação das atividades das empresas. Uma empresa não pode apenas executar o processo, ela tem que ter o poder de desenvolver uma melhor maneira de realizá-lo. Segundo Hamel e Prahalad (1995) isso é realizado com mais facilidade por uma empresa que possua uma competência essencial dessa área. Assim, a identificação de competências essenciais torna-se de fundamental importância para o bom andamento do processo.

A execução de um cronograma exige um processo em forma de rede de interdependências. Encarado desta maneira, este método pode mostrar quais competências serão necessárias na construção e quais competências serão de extrema importância na busca de um ótimo resultado.

O caminho crítico é uma seqüência de atividades críticas as quais não possuem folga de tempo para serem realizadas. Caso a data destas atividades ao longo do processo sejam alteradas devido a alguma causa interna ou externa, todo cronograma da obra e a data de realização de todas as outras atividades seguintes será alterado (CUKIERMAN, 1993).

Desta maneira deve-se dar maior importância as competências relacionadas as atividades críticas pois, segundo Lampel (2001), feita a definição das atividades e as seqüências dos projetos, a empresa contratante tem que dispor de toda a gama de conhecimento, tanto 
explícito quanto tácito, necessários para resolver os problemas da execução. Muito desse conhecimento está centrado nas competências essenciais das empresas que participarão do projeto.

\subsection{Considerações finais}

Como visto, a construção civil possui um grande número de características que auxiliam o processo de formação de redes de empresas. O quadro 4.1 aloca as competências essenciais dentro do setor da construção civil. 


\begin{tabular}{|c|c|c|c|c|}
\hline \begin{tabular}{|c|}
$\begin{array}{c}\text { Setor da construção } \\
\text { civil }\end{array}$ \\
\end{tabular} & Considerações importantes & Relacionamento com as competências essenciais & $\begin{array}{c}\text { Nível de hierarquia Hamel e } \\
\text { Heene (1994) } \\
\end{array}$ & $\begin{array}{c}\text { Posicionamento na rede a } \\
\text { partir Britto (2002a) }\end{array}$ \\
\hline $\begin{array}{l}\text { 1- Mercado da } \\
\text { construção civil }\end{array}$ & O produto tem que ter o valor reconhecido pelo cliente. & $\begin{array}{l}\text { Não há relação direta, porém são as competências essenciais } \\
\text { que agregam ao produto os benefícios fundamentais aos clientes. }\end{array}$ & Meta competência essencial & Fora da rede \\
\hline \begin{tabular}{|l|} 
2- Processo \\
construtivo \\
\end{tabular} & $\begin{array}{l}\text { O processo de construção pode ser dividido por várias } \\
\text { empresas. }\end{array}$ & $\begin{array}{l}\text { Existe uma competência essencial para cada parte do processo } \\
\text { construção. }\end{array}$ & Competência essencial & Toda a rede \\
\hline 3- Subcontratação & $\begin{array}{l}\text { Processo de contratação de empresas especializadas para } \\
\text { cada subprocesso da obra. }\end{array}$ & $\begin{array}{l}\text { Na busca de empresas especializadas, a competência essencial } \\
\text { pode ser um critério importante. }\end{array}$ & Competência essencial & Nós da rede \\
\hline 3.1- Seleção & Análise das ofertas de serviço dos subempreiteiros & $\begin{array}{l}\text { Uma empresa que possui uma competência essencial pode } \\
\text { oferecer melhores serviços. }\end{array}$ & Habilidades constituintes & Nós da rede \\
\hline 3.2- Avaliação & $\begin{array}{l}\text { Definição dos parâmetros e critérios de análise das ofertas } \\
\text { de serviço. }\end{array}$ & $\begin{array}{l}\text { Se uma empresa possui uma competência essencial então é uma } \\
\text { forte concorrente ao cargo. }\end{array}$ & Competência essencial & $\begin{array}{l}\text { Nós da rede e possível } \\
\text { avaliação para suprir as } \\
\text { posições e fluxo }\end{array}$ \\
\hline $\begin{array}{l}\text { 3.3-Formalização da } \\
\text { contratação }\end{array}$ & $\begin{array}{l}\text { Definição de regras e cláusulas a serem seguidas durante } \\
\text { a elaboração do contrato entre as partes. }\end{array}$ & $\begin{array}{l}\text { Obrigações dos subcontratados em relação aos contratantes } \\
\text { podem exigir competências essenciais. }\end{array}$ & Habilidades constituintes & Ligações da rede \\
\hline 3.4- Organização & $\begin{array}{l}\text { Diretrizes de gerenciamento dos subempreiteiros durante } \\
\text { sua permanência no canteiro de obras e de avaliação da } \\
\text { prestação do serviço de assistência técnica. }\end{array}$ & $\begin{array}{l}\text { Posicionamento e gerenciamento das empresas a partir da } \\
\text { avaliação das competências essenciais. }\end{array}$ & Competência essencial & Posições e ligações \\
\hline 4- Qualidade da obra & O cliente exige qualidade. & $\begin{array}{l}\text { Empresa com competência essencial desenvolve excelência em } \\
\text { serviços. }\end{array}$ & Meta competência & Nós ou toda a rede \\
\hline $\begin{array}{l}\text { 5- Inovação de } \\
\text { materiais e métodos } \\
\text { de construção } \\
\end{array}$ & $\begin{array}{l}\text { A inovação é de fundamental importância para na atual } \\
\text { competitividade e na busca de itens mais baratos. }\end{array}$ & $\begin{array}{l}\text { Uma empresa que possui uma competência essencial é capaz de } \\
\text { desenvolver novos produtos. }\end{array}$ & Competência essencial & Nós ou toda a rede \\
\hline $\begin{array}{l}\text { 6- Processo de } \\
\text { licitação }\end{array}$ & Estar na frente de qualquer outra empresa concorrente. & $\begin{array}{l}\text { A competência essencial pode ser um dos critérios de avaliação } \\
\text { da empresa concorrente. }\end{array}$ & Meta competência & Toda rede \\
\hline 6.1-"Melhor técnica" & $\begin{array}{l}\text { Uma empresa precisa demonstrar que é capaz de realizar } \\
\text { o serviço. }\end{array}$ & $\begin{array}{l}\text { Uma empresa que possui uma competência essencial é capaz de } \\
\text { realizar o serviço. }\end{array}$ & Habilidades constituintes & Nós \\
\hline 6.2- "Melhor preço" & $\begin{array}{l}\text { Processos de licitação utilizam como o principal critério um } \\
\text { melhor preço. }\end{array}$ & $\begin{array}{l}\text { Uma empresa que possui uma competência essencial possui } \\
\text { muitas maneiras de baratear custos. }\end{array}$ & $\begin{array}{l}\text { Competência } \\
\text { essencial }\end{array}$ & Nós ou toda a rede \\
\hline $\begin{array}{l}\text { 7- Cronograma de } \\
\text { uma obra }\end{array}$ & $\begin{array}{l}\text { Todo o planejamento de uma obra é feito através de um } \\
\text { cronograma. }\end{array}$ & $\begin{array}{l}\text { As competências essenciais podem diminuir tempo e melhorar } 0 \\
\text { andamento da obra. }\end{array}$ & Meta competência & Toda rede \\
\hline 7.1- Atividades & O cronograma da obra é composto por todas as atividades. & $\begin{array}{l}\text { Cada atividade tem que ser desenvolvida por uma empresa que } \\
\text { possua uma competência essencial relacionada ao serviço. }\end{array}$ & Habilidades constituintes & Nós e posições \\
\hline $\begin{array}{l}\text { 7.2- Tempo de cada } \\
\text { atividade }\end{array}$ & $\begin{array}{l}\text { O tempo de realização de cada atividade é estabelecido } \\
\text { para o bom andamento do processo. }\end{array}$ & $\begin{array}{l}\text { Empresa que possui competência essencial demonstra confiança } \\
\text { quanto a entrega do serviço. }\end{array}$ & Competência essencial & Posições ligações e fluxos \\
\hline $\begin{array}{l}\text { 7.3- Atividades } \\
\text { críticas }\end{array}$ & $\begin{array}{l}\text { O atraso de uma atividade crítica compromete todo } 0 \\
\text { andamento da obra. }\end{array}$ & $\begin{array}{l}\text { Enfatiza a importância de buscar empresas com competências } \\
\text { essenciais, principalmente para estas atividades. }\end{array}$ & Competência essencial & Posições ligações e fluxos \\
\hline
\end{tabular}

Quadro 2 - Competências inseridas no processo de construção civil. 


\section{COLETA DE DADOS}

A coleta de dados baseou-se nas questões apresentadas na introdução, propostas por Javidan (1998). Nesse sentido, faz-se uma apresentação da obra do metrô - Linha 4 relativa às obrigações dos contratantes em relação aos subcontratados e vice-versa. Em seguida identificam-se as empresas que compõem o consórcio. As empresas subcontratadas estão em segundo nível e não fazem parte do escopo para definição do consórcio. Identificam-se os pontos da cadeia de valor em que cada empresa se situa e a capacidade, competência ou competência essencial para realização da obra. Finalmente, verifica-se a ligação existente entre as competências essenciais das referidas empresas e as vantagens competitivas.

\subsection{Apresentação da obra do metrô - Linha 4, Amarela}

As informações apresentadas nesse item foram obtidas na documentação de licitação da obra e em documentos eletrônicos encontrados na página de informações da Companhia Metropolitana de São Paulo.

A obra do metrô - Linha 4, AMARELA, ligará o bairro da Luz ao bairro de Vila Sônia, na Zona Oeste, passando pela região da Consolação, Avenida Paulista e Pinheiros; ela consiste em duas etapas. A primeira etapa da obra (em andamento) inclui a construção de 12,8 quilômetros de vias entre o pátio de Vila Sônia e a Estação Luz. Nesta etapa, está prevista a construção de 12,8 km de túneis e cinco estações: Butantã, Pinheiros, Paulista, República e Luz e dos sistemas elétricos para funcionamento deste trecho da linha (ANEXO A).

O fornecimento dos conjuntos de equipamentos eletromecânicos e a instalação de um sistema de telecomunicações poderão ser inéditos no país e um dos mais avançados do mundo, por dispensar a utilização de fios. Tais equipamentos, no futuro, reduzirão as despesas com a manutenção porque mais rapidamente identificarão eventuais problemas. As estações poderão contar com recursos de telecomunicações e informática típicos de edifícios inteligentes, como funcionários equipados com terminais portáteis de voz e dados que permanentemente estarão conectados à rede local (LAN) e à rede wireless (WI-FI), de modo a monitorar os ambientes e supervisionar todos os demais sistemas das estações. 
O sistema prevê também recursos de multimídia, como painéis informativos e totens interativos, que disponibilizarão, aos usuários, as informações relativas à operação do metrô, inclusive com a possibilidade de veiculação de propaganda comercial.

Estão previstas para a segunda etapa as operações de seis estações - Morumbi, Três Poderes, Faria Lima, Fradique Coutinho, Oscar Freire e Higienópolis - a fabricação de trens, sinalização e complemento do sistema de telecomunicação. Os investimentos previstos são de R \$ 3,1 bilhões, sendo 1,9 bilhão na primeira fase e R \$ 1,2 bilhão na segunda etapa, com recursos do Tesouro do Estado, Japan Bank for International Cooperation (JBIC) e também da iniciativa privada junto ao Banco Internacional para Reconstrução e Desenvolvimento (BIRD).

Quando entrar em operação, em 2008, a Linha 4 do Metrô de São Paulo (CMSP) será a mais importante da cidade por integrar todas as demais linhas do Metrô. Com a Linha 1-Azul, na Estação Luz; com a Linha 3-Vermelha, na Estação República; e com a Linha 2-Verde, na Estação Paulista. Além disso, fará conexão com a Linha C da Companhia Paulista de Trens Metropolitanos (CPTM), na Estação Pinheiros, que está interligada à Linha 5-Lilás pela Estação Santo Amaro (ANEXO A).

A obras tiveram início no segundo semestre de 2004, a previsão de conclusão da primeira fase é 2007. A demanda estimada para esse trecho é de 1 milhão de passageiros por dia, unindo a região central à zona oeste do município. A Linha 4-Amarela, ao integrar as outras linhas, permitirá um acréscimo de 35\% na demanda diária de passageiros. A segunda etapa que contemplará a construção das outras seis estações deverá ser entregue em 2010.

A Linha 4-Amarela tem seu percurso todo subterrâneo. Calcula-se que cerca de 30 mil novos postos de trabalho serão criados na construção civil, fabricação de equipamentos, montagens e serviços.

Os consórcios responsáveis pela construção da linha são: Consórcio 1, formado pela Empresa A, Empresa B, Empresa C e Empresa D e o Consórcio 2, formado pela Empresa E, Empresa F e Empresa G. O primeiro vai construir os 12,8 quilômetros de vias e estações; e o segundo executará as obras do pátio de manutenção de Vila Sônia.

A Linha 4 terá a alimentação dos trens realizada através de catenária rígida, com nível de tensão de 1500 Vcc, ao invés da configuração tradicional de terceiro trilho, com nível de tensão de 750 Vcc. Esta nova configuração técnica possibilita a redução do número de subestações retificadoras.

A Companhia Metropolitana de São Paulo utilizou o processo de licitação para a contratação da empresa responsável pela construção da obra. A empresa contratada tem como 
objetivo a construção e execução das obras civis, bem como o fornecimento e implementação de equipamentos e sistemas necessários à primeira fase do empreendimento.

Este processo de licitação tem a modalidade de Concorrência Internacional com divulgação ampla, nacional e internacional, com realização de audiência pública e é dividida em (3) três lotes assim definidos: Lote 1 - Paulista - de Luz a Fradique Coutinho; Lote 2 Pinheiros - de Fradique Coutinho a Vila Sonia; Lote 3 - Pátio Vila Sônia (ANEXO A).

Os agentes mais importantes desta licitação são: o Cliente, Companhia Metropolitana de São Paulo e o Contratado, empresas cuja oferta foi aceita pelo Empregador. O contratado pode ser formado por um consórcio que limita-se a quatro membros.

A primeira etapa desta licitação foi a pré-qualificação de empresas construtoras, fornecedoras de serviços de engenharia. Os competidores, pessoas jurídicas, poderiam ser individuais ou reunidos em consórcio, porém tiveram que atender às condições mínimas de habilitação e comprovar experiências gerais e especificas bem sucedidas em empreendimentos com características de porte compatíveis com o objeto da licitação. Atividades previstas em contrato são: trabalhos civis (demolição de edificações, construção de túneis, construção de estações, construção de rotas permanentes, serviços de paisagismo e urbanização) e sistemas (provisão de energia de alta, média e baixa voltagem, sistemas de energia de tração, sistemas auxiliares, sistemas de telecomunicação, sistemas de controle local, iluminação, escadas rolantes e elevadores).

A empresa ou consórcio que está realizando a obra teve que comprovar estar apta a realizar todos esses serviços e outros mais que estão em contrato. O processo de seleção também exige capacidades financeiras.

O candidato teve que demonstrar ter acesso ou possuir ativos disponíveis, linhas de crédito e outros meios financeiros suficientes para satisfazer às exigências de fluxo monetário da construção. Também teve que demonstrar, para a satisfação do empregador que possui adequadas fontes de finanças para satisfazer, atualmente, às exigências de fluxo monetário para compromissos de contrato de futuro. Outras demonstrações financeiras aceitáveis pelo empregador foram a honestidade demonstrada durante os últimos cinco anos e a rentabilidade ao longo desse prazo. Se julgar necessário, o empregador terá autoridade para fazer investigações bancárias do candidato. O candidato teve que demonstrar que, durante o período anterior, gerou movimentação média anual maior que uma quantia declarada na licitação (em média U\$30.000.000,00 por lote). Esta movimentação é definida com o total de certificados de pagamentos, para trabalhos em progresso ou completados pela empresa, divididas pelo número de anos decorridos. 
O concorrente também tem que relatar a capacidade de equipamento que possui e demonstrar que, baseado em compromissos conhecidos, os equipamentos estarão disponíveis para uso oportuno, proposto em contrato. Podem ser listados no contrato os tipos alternativos de equipamento que poderiam ser propostos pra uso, acompanhados de explicação na proposta.

O contratante deve fabricar, obter e transportar para o canteiro de obra, de maneira ordenada e planejada, todos os equipamentos e sistemas. Todos os custos, maneira e autorização das autoridades, se necessárias, para o transporte dos equipamentos serão de total responsabilidade da empresa contratada. O Empregador apenas ajuda o contratante a obter tais aprovações.

Entre o maquinário necessário estão: máquinas de lançar concreto projetado, guindastes, locomotivas elétricas, caminhão com andaime; máquinas de perfuração de túneis, rolo pé de cabra e escavadoras.

Quanto à subcontratação, a empresa pode subcontratar até 20\% dos trabalhos civis e todo o equipamento a ser utilizado. Além disso, se o candidato pretende subcontratar mais que $10 \%$ do valor do contrato, a intenção tem que ser declarada junto com a lista dos elementos a serem subcontratados. Os fabricantes do equipamento a ser utilizado não precisam ser préqualificados nem serem listados na fase de pré-qualificação porém, nas ofertas, os licitantes terão que relacionar todos os equipamentos com especificações técnicas e autorização de fabricante para utilização dos equipamentos. Se um dos candidatos pretender subcontratar empresas especializadas, ele deve identificar a empresa subcontratada e descrever as capacidades e experiências das mesmas. As empresas subcontratadas não podem ser sócias de qualquer candidato.

O contrato é do tipo Turn-Key (entrega pronta para a operação). A apresentação e seleção de proposta comercial são feitas pelo critério de “menor preço” (Lei 8.666/93). O prazo de execução considerado no contrato é quatro anos.

O consórcio tem que, coletivamente satisfazer os critérios de qualificação. Cada empresa, individualmente tem que satisfazer os seguintes critérios; experiência geral para um período de tempo declarado, fontes adequadas para atender compromissos financeiros e bom estado financeiro.

Um dos sócios, que é nomeado para o comando durante a pré-qualificação e para a execução do contrato, está autorizado a receber instruções e adquirir responsabilidades por qualquer sócio. 
O acordo de consórcio entre os sócios é submetido ao empregador junto com a candidatura e esta, entre outras coisas, inclui: objetivo do consórcio, estrutura de administração, contribuição de cada sócio, recursos e sanções dentro do consórcio.

\subsection{As empresas dos consórcios}

Foram analisadas as empresas de acordo com seu histórico. As informações contidas nesse item foram extraídas dos currículos apresentados pelas empresas em meio eletrônico.

\subsubsection{Empresa A}

A Empresa A, uma construtora que existe desde 1945 em Salvador (BA), iniciou suas atividades com a construção de prédios. Nos anos 60, a empresa expandiu sua atuação para o Nordeste, acompanhando o desenvolvimento da infra-estrutura industrial da região, estimulado pela ação da Sudene. Em Pernambuco, a empresa construiu os parques industriais da Coperbo, das Tintas Coral, da Alpargatas e da Rhodia, entre outros.

No final dos anos 60, o desenvolvimento de obras de logística complexa ajudou a capacitar as equipes da empresa para construir a Barragem de Pedras, sobre o Rio de Contas, na Bahia, com 408 metros de extensão e 70 metros de altura, e a Ponte Propriá-Colégio, sobre o Rio São Francisco, na divisa de Sergipe e Alagoas, com 832 metros de extensão e fundações na rocha em profundidades de até 70 metros sob o rio.

Ainda no final dos anos 60, a empresa iniciou sua expansão para o Sudeste do país, e construiu obras de tecnologia especial, como o Aeroporto Internacional do Galeão, as Usinas Nucleares Angra I e II, no Rio de Janeiro e a Ponte Colombo Salles, em Santa Catarina.

Em 1979, com a construção da Hidrelétrica Charcan V, no Peru, e as obras de desvio do Rio Maule, no Chile, para a construção da Hidrelétrica Colbún-Machicura, a Empresa A deu início à sua carreira internacional.

Na década de 80, a Empresa A incorporou outra empresa, construiu, entre outras, as usinas de Itaipu, Xavantes, Capivara, Nova Avanhandava, Rosana e Foz do Areia; as rodovias dos Imigrantes, dos Trabalhadores e Castelo Branco, entre outras. Em 1984, a construtora iniciou em Angola, a 400 quilômetros de Luanda, a construção da Hidrelétrica de Capanda. Em 1986, a Empresa A, passou a atuar no segmento de construção industrial. A empresa adquirida já participara da montagem de cerca de $40 \%$ de todo o complexo siderúrgico e da instalação de mais de um terço do parque hidrelétrico do país. Em 1988, teve início a atuação na Europa, com a compra de uma empresa de Portugal que permitiu a participação em empreendimentos da infra-estrutura portuguesa, como a ampliação da Auto-Estrada Nacional 
1, a Ponte Vasco da Gama, a Via Infante Dom Henrique, no Algarve, e trechos e estações do metrô de Lisboa.

Na década de 90, a Empresa A ingressou nos Estados Unidos, quando venceu a concorrência para a ampliação do Metromover, metrô de superfície que serve à área central de Miami, na Flórida, participou da ampliação do aeroporto de Miami e liderou o consórcio para a construção do primeiro trem-bala americano.

Nos anos seguintes, realizou outras obras em território americano, como a Barragem de Seven Oaks, na Califórnia, concluída em 1999, e o ginásio de esportes American Airlines Arena, em Miami, inaugurado em janeiro de 2000.

Em 2005, a empresa está presente em países da América do Sul, América do Norte, África e Europa.

\subsubsection{Empresa B}

A Empresa B é uma empresa de construção, fundada em 1976 que atua em concessões na Área de Transporte; construção de edificações, construção de usinas hidrelétricas e termelétricas; construção de indústrias automotivas, bebidas, alimentação, papel e celulose, químicas, metalúrgicas, siderúrgicas; obras de infra-estrutura do tipo barragens, irrigação, canais, infra-estrutura urbana e urbanização de favelas; energia, petróleo e gás; petroquímicas, refinarias, oleodutos e dutos; saneamento , meio ambiente e adutoras, redes e Estações de Tratamento de Esgotos (ETE), redes e Estações de Tratamento de Água (ETA), reservatórios, emissários submarinos, desassoreamentos, canalizações e drenagens.

\subsubsection{Empresa C}

A Empresa C, uma holding ${ }^{3}$, foi fundada no Recife em 13 de Abril de 1953, atua nas áreas de rodovia, saneamento, exploração de petróleo, energia, abastecimento, concessão de serviços públicos, finanças, entre outras.

Nas décadas de 60 e 70 destacou-se na execução de obras das barragens de Carpina, Goitá e Tapacurá, que integram o Programa Especial de Controle de Enchentes e Recuperação de Vales, empreendimentos imobiliários. Implantou a Pedreira Guarany em Jaboatão dos Guararapes, no Estado de Pernambuco, operando na industrialização e comercialização de produtos de britagem.

\footnotetext{
${ }^{3}$ A holding pode ser definida como uma empresa que opera em vários setores da economia.
} 
Na década de 80 constituiu uma sede no Rio de Janeiro, para a exploração de petróleo e de gás natural no Brasil e no exterior. Criou uma empresa dedicada à produção e comercialização de pré-moldados de concreto, uma empresa de mineração no Rio de Janeiro, com o objetivo de trabalhar na prospecção e exploração de jazidas minerais e uma empresa no Recife no ramo de planejamento técnico-empresarial e iniciou a execução de obras de engenharia no Uruguai e em outros países da América do Sul.

Na década de 90, criou uma empresa para a execução de obras em áreas rurais. Iniciou investimentos na área de transporte urbano de passageiros do Recife, ampliou os investimentos no setor de produção agrícola com a formação da Guararapes Agrícola S/A, criou um banco atuando com sede no Recife, adquiriu o controle acionário da Companhia Siderúrgica Vale do Pindaré, sediada no município de Açailândia, no Estado do Maranhão. Criou uma empresa de meio ambiente, com sede no Rio de Janeiro, atuando em limpeza urbana e operação de aterros sanitários e inertes. Obteve a primeira concessão à iniciativa privada para produção de energia elétrica, incluindo a construção e operação da Usina Hidroelétrica de Santa Clara, no Norte de Minas Gerais. Iniciou trabalhos de concessão de serviços públicos no setor de saneamento no Estado do Rio de Janeiro, com as Concessionárias Águas de Juturnaíba, Águas de Niterói, Águas do Imperador e Águas do Paraíba. É responsável pelas obras "Ponte do Morumbi, em São Paulo, e o Programa Especial de Controle às Enchentes e Recuperação de Vales - Projeto Vale do Capibaribe”, no Estado de Pernambuco. Em parceria com outra empresa, na Bacia de Camamu (BA), faz a exploração de um campo de gás natural, cujas reservas contidas foram estimadas em um mínimo de 23 bilhões de metros cúbicos.

\subsubsection{Empresa D}

A Empresa D, uma empresa multinacional, líder mundial em energia e transporte projeta, fabrica e da manutenção de produtos e sistemas de alta tecnologia destinados a atender às crescentes necessidades de infra-estrutura em energia e transporte em todo o mundo.

Construiu centrais elétricas que fornecem $20 \%$ da capacidade mundial instalada de geração de energia. Fabricou trens de alta velocidade (TGV) que circulam na França, Coréia, Londres, Nova Iorque e Paris. A empresa tem uma ampla gama de produtos destinados aos setores da energia, do transporte ferroviário e da construção naval.

No setor de energia a empresa realiza construção de turbinas, geradores, centrais elétricas, caldeiras, sistemas ambientais, serviços, etc. Em transportes ferroviários, trens de alta velocidade (TGV), Metrôs, Tramways (bondes), trens regionais, locomotivas, sinalização etc. 
A empresa também realiza construção de navios de cruzeiro, militares, científicos, tanques etc.

Hoje a empresa está presente em 70 países, com 77.000 especialistas, dos quais 2.900 no Brasil.

\subsubsection{Empresa $\mathbf{E}$}

Com 16 empresas e cerca de 33 mil funcionários, o Grupo ao qual pertence a Empresa E começou como construtora, em 1939, e avançou para outras áreas. Diversificado, o Grupo oferece produtos e soluções em Engenharia, produção de cimento, tecidos, calçados, siderurgia e metalurgia, meio ambiente, serviços na área de rodovias, geração e distribuição de energia elétrica.

A maioria das unidades de negócio está relacionada ao setor da construção e assim todas elas podem participar da obra do metrô.

As cinco empresas que compõem o setor de Engenharia e Construção reagiram prontamente à forte retração do mercado em 2003, implementando o plano de reorganização desenhado desde 2002. As três novas Unidades de Negócios, Infra-Estrutura, Construções e Edificações e Incorporação introduziram novos modelos internacionais para uma gestão afinada com ganhos de sinergia, a busca de soluções inovadoras para os clientes e a exploração de novas oportunidades de negócios, inclusive no exterior.

As unidades de negócio desta empresa dividem-se em: infra-estrutura (engenharia, energia, transmissão e distribuição, indústria e transporte); construções e edificações, incorporação, construções e comércio (participou da construção das hidrelétricas de Tucuruí, Itaipu e Ilha Solteira, aeroportos internacionais (Guarulhos e Campinas), as principais rodovias do Estado de São Paulo e o metrô da capital, a ponte Rio-Niterói e o gasoduto Bolívia-Brasil); engenharia (soluções integradas de engenharia com atividades como estudos e planejamento; engenharia básica; detalhamento e integração; meio ambiente; e gerenciamento de sistemas; atuam na construção de vias expressas, obras de saneamento básico, estradas, ferrovias, hidrovias, portos, aeroportos, metrôs, complexos hidrelétricos e sistemas computadorizados de informação geográfica); empresa de sistemas construtivos préfabricados, desenvolvimento imobiliário e equipamentos e sistemas. 


\subsubsection{Empresa $F$}

A Empresa F é uma construtora fundada em 1948. Essa empresa pode se encarregar de todas as etapas de um empreendimento de construção civil: projeto de viabilidade de engenharia, identificação de investidores, levantamento de recursos financeiros e gerenciamento da implantação e operação posterior do empreendimento.

O Negócio Construção da Empresa F conta com duas estruturas independentes: Negócio Construção Brasil e Negócio Construção Internacional. No início de 2000 foi criada a holding Empresa F, que supervisiona e define as estratégias de negócio do grupo, e atua em construção pesada, telecomunicações, concessões públicas e empreendimentos imobiliários.

O Grupo está organizado da seguinte forma:

A Empresa F- Construção Pesada, com estruturas independentes de atuação para o Brasil ('Construção Brasil') e para os demais países ('Construção Internacional');

A Empresa F- Concessões, holding das concessões de serviços públicos, cujas funções são o comando dos negócios existentes em rodovias, saneamento e transporte público, e o desenvolvimento de novas oportunidades;

A Empresa F- Telecomunicações, holding dos negócios em telecomunicações, com a responsabilidade de coordenar e potencializar os negócios atuais no segmento e desenvolver oportunidades;

A Empresa F- Investimentos Imobiliários, que desenvolve resorts e empreendimentos residenciais.

\subsubsection{Empresa G}

A Empresa G, uma empresa multinacional, começou a atuar no Brasil em 1867 com a execução, fornecimento e instalação da primeira linha telegráfica no Brasil, entre a residência do imperador, no Rio de Janeiro, e a província de São Pedro, o atual Estado do Rio Grande do Sul. Em 1874, instalou o primeiro cabo submarino da América do Sul, entre o Rio de Janeiro e a foz do rio Chuí, no Uruguai, em uma extensão de aproximadamente 2.500 quilômetros. Um projeto complexo que demandava o uso de navios construídos e especialmente equipados para isso. Em 1894, a Empresa G instalou a primeira usina a vapor para a geração de eletricidade em Belém, no Pará.

Também em 1894, fundou uma representação no Rio de Janeiro. A Empresa G foi concessionária da Cia. Ferrocarril Vila Isabel e também a fundadora da Cia. Telefônica do Rio de Janeiro tendo instalado o primeiro centro telefônico da então capital da República para 
8 mil linhas. Em 1900 deu inicio às instalações telefônicas e telegráficas para empresas privadas e à construção de várias usinas de energia, como as das cidades de Ribeirão Preto, Jaú e Rio Claro, no Estado de São Paulo. Em 1905 a Empresa G no Rio de Janeiro, fundou a primeira empresa eletrotécnica multinacional a estabelecer-se no Brasil. A primeira central diesel-elétrica do Brasil é instalada pela Empresa G no Teatro Municipal do Rio de Janeiro e a primeira central telefônica automática do Brasil é instalada em Porto Alegre, Rio Grande do Sul.

Em 1939 a Empresa G instalou em São Paulo a primeira fábrica de transformadores do Brasil e em 1953 inaugurou a primeira central automática de telex da América do Sul, na Diretoria de Rotas Aéreas, Rio de Janeiro. Ainda na década de 50 fundou uma indústria de componentes eletrônicos.

Em 1960 construiu em Salvador uma central telefônica. Em 1965 inaugurou uma fábrica em Gravataí, Rio Grande do Sul, para a produção de componentes eletrônicos. Instalou a primeira linha de pintura eletroforética da América Latina na fábrica da Volkswagen; Centro de Treinamento, em Curitiba; implantou a unidade de Pesquisa e Desenvolvimento em Telecomunicações e inaugurou a fábrica de Curitiba, para a produção de equipamentos e sistemas de telecomunicações.

Em 1983, fabricou o primeiro gerador para a Usina Hidrelétrica de Itaipu com potência de 823,6 MVA e iniciou a fabricação das centrais digitais de comutação pública EWSD.

Na década de 90, a Empresa G passou a ser centro de competência mundial para a fabricação de hidrogeradores. Em 1997, a Empresa G inaugurou o primeiro múltiplo trem trifásico do Brasil para a estrada de ferro do Estado de São Paulo. Em 2001 fez o primeiro contrato assinado para redes e aparelhos Global System Móbile (GSM). São lançados no mercado brasileiro os telefones celulares da Empresa G e um centro para pesquisa e desenvolvimento de tecnologia para telefones celulares é construído em Manaus.

\subsection{Hierarquias de competências}

A hierarquia de competências descrita por Javidan (1998), foi coletada segundo as obrigações contidas na licitação da obra. Cada empresa foi analisada segundo suas obrigações e seu lote de construção. As exigências para construção dos lotes 1 e 2 demonstram as hierarquias de competências que as empresas A, B e C, pois estas vão realizar o processo de construção civil dos lotes 1 e 2. Da mesma maneira, foi analisada a hierarquia de competências das empresas E e F que irão realizar a construção civil do lote 3. A hierarquia 
das empresas de sistemas $D$ e $G$ foram analisadas de acordo com as exigências para a instalação de sistemas de cada lote 1, 2 e 3 da licitação.

\subsubsection{Recursos}

A coleta de dados sobre os recursos foi feita com base na interpretação de BANERJEE (2003) que caracteriza os recursos como físicos (por exemplo, matérias-primas, equipamento, dom financeiro etc.) e recursos humanos (por exemplo, engenheiros, administradores etc.). Apoiado em Major, Asch e Cordey-Hayes (2001) os recursos das empresas foram as condições primárias para elas em suas estratégias na formação do consórcio. Alguns dos recursos, em princípio, são igualmente acessíveis a todas as empresas.

Empresas A, B e C:

Entre os recursos físicos para a instalação dos lotes 1 e 2 podem ser destacados: máquina de lançar concreto projetado; planta de concreto projetado; planta de ar comprimido para Shield; guindaste de canteiro com levantamento elétrico; locomotiva elétrica; caminhão com andaime; máquina de perfuração de túnel.

Recursos humanos exigidos: cinco gerentes de projetos graduados há 15 anos; quatro gerentes de trabalho graduado há 12 anos; quatro chefes de produção graduados há 12 anos e quatro chefes de planejamento graduados há 12 anos. Por sua grande estrutura e histórico, as três empresas mostram claramente possuir todos esses recursos humanos e outros especializados para construção civil; engenheiros, mestre de obras, administradores, pedreiros etc. Possuem hoje, no Brasil, aproximadamente 30000 funcionários.

\section{Empresa D:}

A empresa $\mathrm{D}$ possui todos os equipamentos necessários à produção de todos os sistemas. Possui uma fábrica, localizada na cidade de São Paulo, que dispõe de tecnologia para a produtividade do sistema. Nessa unidade, fabricam-se carros de metrô ferroviários, em aço inoxidável. Também desenvolve e produz todo o equipamento de tração para carros ferroviários.

Em seus recursos humanos, a licitação exige cinco gerentes de sistemas graduados há 12 anos. Além disso, a empresa possui técnicos, engenheiros, recursos humanos de vários outros setores para formar a totalidade da empresa.

Empresas E e F:

As empresas E e F possuem os seguintes equipamentos para a construção do lote 3: rolo de pé de cabra vibratório; carregador rubber-tired; escavadora; rematador vibratório de asfalto. 
Os recursos humanos dessas empresas são: cinco gerentes de projetos graduados há 15 anos; quatro gerentes de trabalho graduados há 12 anos; quatro chefes de produção graduados há 12 anos e quatro chefes de planejamento graduados há 12 anos. As duas empresas mostram claramente possuir todos estes recursos humanos e outros, especializados para construção civil; Engenheiros, Mestre de Obras, Administradores, Pedreiros etc.

\section{Empresa G:}

A empresa $\mathrm{G}$, assim como a empresa $\mathrm{D}$, possui todos os equipamentos necessários para a produção de todos os sistemas do lote 3. Possui doze fábricas e quatro centros de pesquisa e desenvolvimento.

Em recursos humanos a licitação exigiu cinco gerentes de sistemas, graduados há 12 anos. Além disso, a empresa possui técnicos, engenheiros e recursos humanos de vários outros setores para formar a totalidade da empresa.

Os dados sobre os recursos financeiros foram coletados de acordo com cada consórcio participante. Os recursos financeiros das empresas do Consórcio 1 são de uma quantia mínima, entre ativos líquidos, reais ativos não ordenados, linhas de créditos e outros meios financeiros de US \$70.000.000,00. A movimentação média anual referente a trabalhos civis dessas empresas é de US \$230.000.000,00 e a de instalação de sistemas é de US $\$ 50.000 .000,00$.

Os recursos financeiros do Consórcio 2 são de no mínimo US \$10.000.000,00 entre ativos líquidos, reais ativos não ordenados, linhas de créditos e outros meios financeiros. A movimentação média anual referente a trabalhos civis destas empresas é de US \$20.000.000,00 e a de instalação de sistemas é de US \$15.000.000,00.

\subsubsection{Capacidade}

As capacidades foram selecionadas segundo a definição de Hafeez, Zhanga e Malak (2002), os quais referem que as capacidades são influenciadas pela análise dos recursos. Porém foi tratada independente dos recursos. Recursos são partes das capacidades. A capacidade se refere à habilidade de uma organização em explorar os recursos (JAVIDAN, 1998). De certo modo, as capacidades ajudam uma empresa a alcançar suas metas, porém elas não são suficientes para trazer outros benefícios para as empresas, como vantagens competitivas.

Empresas A, B e C:

Estas empresas possuem a capacidade de executar: escavação de túnel em Shield com seção mínima de corte de $25 \mathrm{~m}^{2}$; escavação de túneis em NATAM (New Austrian Tunneling 
Method)em área urbana; estação subterrânea em área urbana; concreto projetado em túneis e serviços de concreto estrutural.

Empresa D:

A Empresa D possui as seguintes capacidades: instalação de subestação de energia de voltagem média; construção de estradas de ferro; instalação de baixos sistemas de distribuição de energia inclusive painéis de transformadores e iluminação; instalação de sistemas de catenária rígida de energia ou sistemas de tensão automático e instalação de sistemas de telecomunicação permanente e multimídia.

Empresas E e F:

Para participar da construção do lote 3 (Pátio da Vila Sônia) estas empresas possuem a capacidade de: serviços em concreto estrutural para edificações; serviços de escavações; trabalhos em estradas e construção de estradas férreas e do pátio para a manutenção do metrô.

Empresa G:

A Empresa G possui capacidade de: instalação de sistemas de voltagem média AC; construção de metrô e estrada de ferro com subestação retificadora DC baseada em diodo; Instalação de baixo sistema de distribuição de voltagem incluindo painéis de transformadores e iluminação e sistemas de telecomunicação de comunicação permanente e multimídia.

\subsubsection{Competências}

Para coleta de informações do próximo nível da hierarquia - as competências - foram analisadas as capacidades que dão condições às empresas para alcançarem suas metas dentro da obra do metrô. As competências são as tarefas executadas ou administradas por uma empresa. Foram extraídas dessa análise as habilidades e conhecimento que são condições prévias para execução de uma tarefa (RITTER e GEMÜNDEN, 2003).

Das várias competências da empresa A, da empresa B e da empresa C, a competência utilizada na construção do metrô foi a de construção de túneis. A empresa D possui a única fábrica de trens em operação no Brasil. Entre as suas competências, foi utilizada na obra do metrô, a de projetar e fabricar carros metrô-ferroviários em aço inoxidável, com o estudo para o dimensionamento da frota, em função da demanda de passageiros requerida. A empresa $\mathrm{E}$ e F possuem competência em construção de estradas e edificações. A empresa $G$ possui competência em distribuição de energia, instalação de sistemas de comunicação, etc.

Todas estas competências são utilizadas para a realização da concepção, projeto, cálculos, testes, construção, até a fase de operação, colocação em serviço e garantia. 


\subsubsection{Competências essenciais}

Foram consideradas competências essenciais as competências mais importantes que trouxerem benefícios e prosperidade para a empresa em longo prazo (HAMEL E PRAHALAD, 1995). Além disto, somente foram consideradas competências essenciais por passarem nos três testes propostos por Hamel e Prahalad (1995): possuir um valor percebido pelo cliente, alguma diferenciação para com seus concorrentes e alguma característica que demonstre sua capacidade de expansão.

A Empresa A possui competência essencial na construção de obras pesadas, validando os testes propostos por Hamel e Prahalad (1995):

- Valor percebido pelo cliente: A Empresa A foi considerada a mais admirada do setor de construção pesada, pela revista Carta Capital / Inter Science - Brasil em 2004.

- Diferenciação entre concorrentes: A Empresa A concluiu, no fim do mês de março de 2004, uma barragem de Concreto Compactado a Rolo (CCR), de 33 m de altura e $150 \mathrm{~m}$ de comprimento. Durante a execução da barragem foi desenvolvida uma tecnologia inédita mundialmente: em um bloco no interior do maciço, a equipe realizou testes para utilizar o CCR na construção de barragens com dupla curvatura, executadas, até então, com concreto convencional. Como as barragens de duplo arco ainda são erguidas de forma artesanal, com utilização de mão-de-obra intensiva, a principal vantagem da aplicação da nova metodologia está na redução do tempo de execução da obra, uma vez que os procedimentos, com a adoção do CCR, passam a ser mecanizados. Além disso, a barragem em duplo arco com CCR, representa uma grande economia, por consomir menos cimento.

- Capacidade de expansão: Em 1991 a Empresa A marcou posição como a primeira empresa a atuar nos Estados Unidos, demonstrando que estava capacitada a atuar em um dos mercados mais exigentes do mundo. Hoje a Empresa A atua em vários paises pelo mundo.

A Empresa B possui competência essencial na construção de obras pesadas, validando os testes propostos por Hamel e Prahalad (1995):

- Valor percebido pelo cliente: Nos últimos 10 anos, sempre figurou entre as 5 melhores empresas nos rankings das publicações especializadas e obteve o prêmio de melhor empresa de construção civil da Revista Exame, por 4 anos 
consecutivos. No ano de 1996, foi classificada como a Maior Empresa brasileira no setor da construção por receita operacional bruta.

- Diferenciação entre concorrentes: a Empresa B utiliza os mais modernos métodos e técnicas disponíveis na engenharia, dentro de rígidos padrões de segurança, profissionais qualificados e comprometidos com o objetivo de oferecer menores custos, comprometimento nos prazos e qualidade.

- Capacidade de expansão: A empresa B trabalha em diversos setores da engenharia. Hoje é capaz de realizar qualquer serviço no setor devido a sua vasta experiência em obras no país e fora dele.

A Empresa C também possui competência essencial em construção de obras pesadas, validando os testes propostos por Hamel e Prahalad (1995):

- Valor percebido pelo cliente: A empresa é certificada pelas normas ISO 9001:2000 e ISO 14001:1996; é reconhecida pelo público através de premiações concedidas por prestigiosas entidades de todo o País.

- Diferenciação entre concorrentes: Utilização de avançados métodos construtivos, aliados à consciência ambiental.

- Capacidade de expansão: A Empresa C conta com profissionais motivados e com formação gerencial diversificada que, atuando em uma estrutura descentralizada, buscam maior proximidade com clientes e parceiros, com vista a identificar e superar as suas expectativas.

A Empresa D possui competência essencial na instalação de sistemas, validando os testes propostos por Hamel e Prahalad (1995):

- Valor percebido pelo cliente: a Empresa D, além de ser uma empresa de grande porte e com um histórico que mostra sua competência essencial muito desenvolvida, já forneceu mais de 600 carros de metrô para São Paulo. Recentemente, foi líder do consórcio que construiu a Linha 5, inaugurada em 2002.

- Diferenciação entre concorrentes: Os trens fornecidos pela Empresa D possuem o mais avançado sistema de tração AC - Onix 1500, com módulos de alimentação a Insulated Gate Bipolar Transistor (IGBT), tecnologia de última geração e que proporciona melhor desempenho, menor índice de manutenção e economia no consumo de energia.

- Capacidade de expansão: O complexo do sistema de Centro de Controle Operacional, o mais moderno do Brasil, foi desenvolvido inteiramente no país e 
fabricado nas unidades locais da Empresa D, reforçando ainda mais a liderança neste segmento de mercado.

A empresa E possui competência essencial na construção de obras pesadas, validando os testes propostos por Hamel e Prahalad (1995):

- Valor percebido pelo cliente: A empresa E trabalha para os maiores organismos nacionais, empresas públicas, companhias estatais e de economia mista, fundações e para as mais diversas empresas privadas, além de ter executado obras fora do nosso país.

- Diferenciação entre concorrentes: Inovadora, a Empresa adota um conceito de construção racional, rápida e econômica, com base em sofisticadas tecnologias de produção.

- Capacidade de expansão: A empresa investe em equipamentos necessários para pesquisa de materiais; na qualificação profissional garantem a incorporação de novas tecnologias. Entre as inovações, está a criação de um acabamento de fachadas que reproduz o granito natural.

A empresa F possui competência essencial na construção de obras pesadas, validando os testes propostos por Hamel e Prahalad (1995):

- Valor percebido pelo cliente: A Empresa F foi vencedora do Prêmio Qualidade 2003 da Petrobrás/Engenharia/IERC, concedido às empresas contratadas para as obras de ampliação da Refinaria Duque de Caxias, no Rio de Janeiro. A empresa foi classificada como a melhor de sua categoria, de acordo com a avaliação do desempenho em auditorias executadas ao longo do ano de 2003.

- Diferenciação entre concorrentes: A Empresa F tornou-se a primeira empresa de construção pesada brasileira a obter a certificação de todos os sistemas de gestão.

- Capacidade de expansão: Em 2003, a empresa ampliou suas atividades com a Petrobrás, inclusive para a execução de obras de montagem de unidades petroquímicas.

A Empresa G possui competência essencial na instalação de sistemas, validando os testes propostos por Hamel e Prahalad (1995):

- Valor percebido pelo cliente: A Empresa G é a única empresa que oferece aos seus clientes, um portfólio completo de aparelhos para usuários finais a complexas infra-estruturas de rede para empresas e operadoras, bem como serviços relacionados. 
- Diferenciação entre concorrentes: A Empresa G oferece Sistemas de Sinalização e Controle que proporcionam a operação econômica em ferrovias de longo percurso e transporte urbano, o que garante a segurança operacional e o bem estar do passageiro.

- Capacidade de expansão: A Empresa G é líder mundial de inovação em tecnologias, produtos e serviços convergentes para redes móveis, fixas e corporativas de telefonia, além de ser o maior grupo e operar em mais de 160 países.

Todas as empresas analisadas, principalmente as que atuam na área de construção civil, possuem competências particulares, porém com finalidades semelhantes. As empresas brasileiras de construção pesada não trabalham apenas com construção. Expandiram para outros negócios em outros setores e essa característica contribui para que possuam as capacidades exigidas para participar do processo de licitação e as competências essenciais necessárias no processo de concorrência.

\subsection{Responsabilidades de cada empresa}

A rede de empresas formada para a construção da linha 4 do metrô de São Paulo é formada por dois consórcios ganhadores da licitação. “Consórcio” é uma modalidade de contrato feito por duas ou mais pessoas para, entre si, constituir uma relação jurídica de natureza patrimonial, com a finalidade de executar determinado empreendimento sem, todavia, estabelecer um vínculo mais rígido ou permanente. No Brasil, a prática do consórcio de empresas é suportada pelo Capítulo XXII da Lei 6404, de 15 de dezembro de 1976 que erige com a modalidade de combinação de empresas para a consecução de empreendimentos conjuntos das várias finalidades. Específica para a formação de consórcio em participação de licitação, existe a Lei 8.666/93 (LEÃO, 2000).

O contrato, por ser do tipo Turn-Key, exigiu a formação do consórcio, porque cada empresa sozinha não possui todas os recursos, capacidades e, conseqüentemente, competências essenciais necessárias para que a obra seja construída com sua finalização pronta para a operação. Assim, além da construção de túneis, poços de ventilação e de toda a estrutura das estações, que serão realizadas pelas empresas com competência essencial em construção civil pesada, a Empresa D e a Empresa G, com sua competência essencial em instalação de sistemas, farão toda a infra-estrutura de sistemas como projeto, fornecimento, instalação e testes dos sistemas de suprimento, distribuição de energia elétrica, equipamentos de telecomunicações e demais sistemas auxiliares. 
Cada consórcio ganhador, coletivamente, satisfaz os critérios de qualificação como capacidade de equipamentos, capacidade pessoal e financeira para cada lote que ganhou. Os sócios do consórcio devem atender aos seguintes critérios individualmente: experiência geral para o período de anos declarados em licitação; fontes adequadas para atingir compromissos financeiros em outros contratos; bom estado financeiro e histórico de litígio.

Todos os sócios dos consórcios são legalmente responsáveis pelo contrato, porém existe apenas um sócio nomeado para o comando do consórcio e este está autorizado a adquirir responsabilidades e instruções em nome de qualquer sócio. Para o Consórcio 1 o comando está a cargo da Empresa A e para o Consórcio 2 a empresa no comando é a Empresa E.

Em cada consórcio, todas as empresas possuem o mesmo poder de decisão e todos os contratos e responsabilidades são tomadas por uma comissão formada por um representante de cada empresa.

O consórcio contratado deve projetar executar, e dar a manutenção de acordo com as provisões de contrato. Também assume toda a estabilidade e segurança no local da obra. $\mathrm{O}$ Empregador ou cliente é responsável pela posse legal física do local de obra e todo o acesso a ela.

Todas as sete empresas (Empresa A, B, C, D, E, F e G), do Consórcio 1 e Consórcio 2 designam um representante a fim de formar uma comissão que cuidará de questões pertinentes e decisões a serem tomadas para um bom andamento na totalidade da obra. Esta comissão reúne-se em um escritório central formado pelas sete empresas. Todas as empresas possuem o mesmo poder de decisão. Assim, para a construção da obra, foi formada uma única rede de empresas simétrica e saturada, cada uma delas mantendo sua individualidade.

Apesar de todas as empresas decidirem em conjunto o andamento da obra, o consórcio ganhador de cada lote é quem executa cada um dos lotes. Além disso, cada consórcio é dividido em dois outros subconsórcios: o construtor, responsável por toda a fase de construção civil e o subconsórcio de instalação de sistemas. Dentro de cada consórcio foi colocada uma empresa instaladora de sistemas e esta vai atuar, em maioria, na etapa de finalização da obra. As outras empresas do consórcio trabalham juntas. No Consórcio 1, o subconsórcio construtor é formado pelas construtoras Empresa A, Empresa B e Empresa C e a Empresa D será responsável pelas instalações de sistemas. No Consórcio 2. o subconsórcio construtor é formado pela Empresa E e Empresa $\mathrm{F}$ e ficará responsável pela instalação dos sistemas a Empresa G. 


\subsection{Subcontratadas}

As empresas subcontratadas e todas as obrigações e deveres das mesmas são de exclusiva responsabilidade dos Consórcios. As empresas subcontratadas participam da obra para execução de trabalhos superespecializados, como o rebaixamento do lençol freático da estação Higienópolis para o que foi subcontratada uma empresa especializada no serviço. As empresas dos consórcios podem até possuir capacidade de fazer estes serviços, porém não possuem competência e muito menos uma competência essencial para realizá-lo; assim buscam uma empresa com competência no serviço, com isso otimizam tempo e até custos.

Apesar de ter que respeitar o contrato no qual só poderiam ser subcontratados apenas 20\% do serviço, várias empresas e vários serviços estão sendo subcontratados para construção das estações e dos poços visitados. Como no contrato os serviços são medidos pelos custos, o custo das empresas subcontratadas são relativamente menores em relação às aquisições de equipamentos de grande porte comprados pelas empresas do consórcio para construção. Assim, os serviços contratados não passam de $20 \%$ do valor total. Como exemplo, o engenheiro de obras do Consórcio 1 mencionou a compra de um equipamento para escavação de túneis no valor de US \$8.000.000 e um serviço subcontratado de R\$10.000.

\subsection{Particularidades observadas em visitas feitas à obra}

Foram visitadas as obras da estação Higienópolis e do poço de ventilação José Eusébio. Pode-se observar toda a operacionalização que será realizada na totalidade da obra, pois a construção seguirá os mesmos arranjos construtivos e será realizado pelas mesmas empresas.

As duas obras estão localizadas na Rua da Consolação (ANEXO A). A estação Higienópolis é enterrada com plataformas laterais, estruturas em concreto aparente e salas de apoio no nível da superfície, bem como duas passarelas de distribuição em estrutura metálica fixada com tirantes - uma sobre cada extremidade da plataforma. Possuirá acesso para pessoas portadoras de deficiência, terá capacidade de 26.820 passageiros por dia e sua área construída será de $12.090 \mathrm{~m}^{2}$.

Nos dois locais já foram construídos os poços com suas devidas contenções. Essas contenções do poço foram realizadas por uma empresa subcontratada com competência essencial em armação. Hoje as obras encontram-se na fase de escavação dos túneis que dão acesso ao túnel central do metrô. As duas obras estão localizadas em local de trânsito intenso, mas o mesmo não sofre interferência alguma da obra em construção pelo fato de a obra ter suas vias e túneis de acesso cem por cento subterrâneas e seu método construtivo de escavação por NATM. 
Alguns dos sistemas serão implantados pelas Empresas D e G; sistema de abastecimento de energia; rede de distribuição de média tensão; subestação primária de; subestações retificadoras; catenária rígida (via dupla); subestações auxiliares; distribuição de baixa tensão; equipamentos de telecomunicações nas estações; comunicação fixa; monitoramento de vídeo multimídia; sistema de controle local; sistemas auxiliares; bandejamento e iluminação (estações e túnel); bombeamento; ar condicionado e ventilação auxiliar para salas técnicas; detecção de incêndio e alarme; bilheterias. As Empresas D e G também serão responsável pelos projetos de infra-estrutura para hidráulica; furos e embutidos; bandejamento e ocupação de espaço do cabeamento.

Para a construção do poço de ventilação José Eusébio e para a construção da estação Higienópolis, cada uma das empresas participantes do Consórcio 1, disponibilizou certo número de funcionários da própria empresa para fazerem as obras. Dentre os funcionários, nem todos tinham a especialização ou aprimoramento no serviço em que estava realizando. Um dos funcionários entrevistados trabalhava com recursos humanos antes da formação do consórcio e, na obra do poço José Eusébio, estava trabalhando com organização de máquinas e ferramentas. O engenheiro responsável pela obra já trabalhou em construção de pontes e estradas e na obra realizava a inspeção de poço e túnel.

Com exceção dos engenheiros e chefes do canteiro de obra, todos os funcionários que estavam dentro das obras trajavam um uniforme que continha nas costas o nome das empresas do Consórcio 1, a menos do nome da Empresa D, instaladora dos sistemas. Este fato se deve a formação dos subconsórcios de construção civil e de instalação de sistemas dentro de cada consórcio principal.

Embora sejam de diferentes empresas os funcionários trabalhavam em harmonia dentro da obra sem demonstrar qualquer diferenciação. As diferenças eram demonstradas apenas entre as camadas ou níveis de poder como engenheiros e mestres de obra. Isso ocorre porque todas as empresas do subconsórcio responsável pela construção civil já atuavam no mesmo setor e possuem os mesmos recursos físicos e humanos, embora em diferentes quantidades.

Nas obras visitadas foram encontrados diversos equipamentos. Dentre eles, existiam equipamentos das empresas, equipamentos alugados pelo consórcio e equipamentos pertencentes ao consórcio. Não foi possível identificar o critério de obtenção desses equipamentos, o porque eram obtidos por uma única empresa ou o porque eram obtidos pelo consórcio. Dentro das obras visitadas foram encontrados os seguintes equipamentos: empilhadeira ou guindaste pertencente a uma única empresa do consórcio; maquinário de concretagem pertencente ao consórcio e caminhões-betoneira alugados pelo consórcio. 
A maioria dos equipamentos aparentava ser novos e, por isso, parecem ter sido adquiridos especialmente para trabalhos que vão ser realizados nesta obra.

\subsection{Considerações finais}

A visita ao local da obra, tornou-se a maneira mais efetiva de coletar dados para a pesquisa. Apesar de não ter percorrido todo o traçado da construção, os dois locais visitados foram de grande valia para obtenção de uma visão de como funciona o todo da obra. Através das entrevistas realizadas nas obras visitadas foi possível reconhecer quem fazia e como fazia as atividades de toda a obra.

Houve dificuldade na obtenção de documentos por motivo de burocracia a qual demandava muito tempo para liberação dos arquivos, devido ao tamanho dos documentos e liberação de todas as empresas que fazem parte do consórcio. Por este motivo, o pesquisador optou por fazer a análise das empresas por meio eletrônico. O documento de licitação, disponibilizado, apontou vários dados e características que eram procurados.

Alguns dos dados foram obtidos em conversas informais com pessoas de empresas subcontratadas que estão vivenciando a obra do metrô. Pode-se dizer que dos métodos utilizados na coleta de dados o mais importante foi a entrevista informal e não estruturada, pois foi esta quem realmente deu a visão do andamento do processo desde a licitação, formação do consórcio e execução do projeto do metrô. 


\section{ANÁLISE DE DADOS E RESULTADOS}

Este capítulo pretende, através da consolidação da revisão bibliográfica com o estudo de caso, apresentar uma sistematização da identificação de competências essenciais para a formação de redes de empresas.

\subsection{Caracterização dos consórcios sob a ótica de redes de empresas}

Em uma primeira análise são colocadas as empresas, que formam o consórcio para as obras da linha 4 do metrô de São Paulo, no formato de rede de empresas

A analise morfológica dos dados encontrados terá como ponto de partida a configuração do quadro 2.1 de Brito (2002a) composta pelos elementos que formam a rede como nó, posição, ligação e fluxos.

\subsubsection{Elementos "Nós"}

Este elemento tem o intuito de definir quais são as empresas, propriamente ditas, que fazem parte do consórcio, chamado aqui de rede de empresas. A boa compreensão da morfologia depende muito desse elemento, pois são as empresas que formam a estrutura da rede como um todo. Por meio dos dados coletados, os nós são todas as empresas que compõem o consórcio e as empresas subcontratadas para a realização de toda a obra do metrô. Excluem-se da rede a empresa do metrô de São Paulo, pelo fato de ser apenas considerada como cliente da obra, e o Banco Internacional para Reconstrução e desenvolvimento (IBRD) por ser uma empresa financiadora do cliente, não do consórcio.

Apesar da maioria das empresas trabalharem como holdings, foi considerado apenas um nó para cada empresa, ou seja, considerando cada nó como a empresa com todas as suas unidades.

As empresas ou nós que demonstraram possuir todos recursos necessários para a construção da obra da Linha 4 do metrô e atenderam a todos os critérios de qualificação exigidos na licitação da mesma; capacidade de equipamentos, financeira e pessoal. e que, deste modo, fazem parte desta rede são: 
Nó A - Empresa A

Nó B - Empresa B

Nó C - Empresa C

Nó D - Empresa D

Nó E - Empresa E

Nó F - Empresa F

Nó G - Empresa G

As empresas subcontratadas também foram consideradas integrantes da rede. Como visto na coleta de dados existem várias empresas subcontratadas, portanto serão representados apenas três nós e um deles, o nó $\mathrm{N}$, como um nó genérico que engloba o restante todas as empresas subcontratadas.

Nó H - Subcontratada H

Nó I - Subcontratada I

Nó N - Subcontratada N

\subsubsection{Elementos "Posições"}

Segundo Brito (2002a), as posições são as atividades que cada nó vai realizar dentro da rede. A posição de cada elemento foi definida segundo suas competências essências. Deste modo, por meio de dados coletados encontramos as principais posições solicitadas para a obra:

Obras de construção civil:

Posição 01- Demolição de edificações;

Posição 02- Remoção de interfaces;

Posição 03- Construção de túneis;

Posição 04- Construção das estruturas;

Posição 05- Construção das estações;

Posição 06- Colocação das vias permanentes;

Posição 07- Paisagismo;

Posição 08- Urbanização.

Instalação de sistemas:

Posição 09 - Sistema de Abastecimento de Energia;

Posição 10 - Rede de distribuição de média tensão;

Posição 11 - Subestação primária; 
Posição 12 - Subestações retificadoras;

Posição 13 - Catenária rígida (via dupla);

Posição 14 - Subestações auxiliares;

Posição 15 - Distribuição de em baixa tensão;

Posição 16 - Equipamentos de Telecomunicações nas estações;

Posição 17 - Comunicação fixa;

Posição 18 - Monitoramento de vídeo Multimídia;

Posição 19 - Sistema de Controle Local;

Posição 20 - Sistemas Auxiliares;

Posição 21 - Bandejamento e iluminação (estações e túnel);

Posição 22 - Bombeamento;

Posição 23 - Ar condicionado e ventilação auxiliar para salas técnicas;

Posição 24 - Detecção de incêndio e alarme;

Posição 25 - Bilheterias.

\subsubsection{Elementos "Ligações"}

A ligação entre as empresas dos consórcios é determinada por um contrato de consórcio (Joint Venture). Este contrato foi submetido com a candidatura do mesmo para a empresa responsável pela disputa da obra do metrô e contém todos os deveres e obrigações de cada sócio do consórcio.

Os contratos realizados entre as empresas, os Consórcios, e as empresas subcontratadas, também são formais e funcionam como contratação de serviços terceirizados.

Dentro de cada consórcio ganhador tem-se a formação de dois outros consórcios; o “subconsórcio construtor” e o “subconsórcio de instalação de sistemas”. Os contratos entre esses subconsórcios são informais, porém cada empresa tem que respeitar suas funções, estabelecidas no contrato dos consórcios.

Também existem ligações entres as sete empresas dos dois consórcios ganhadores. Estas ligações funcionam informalmente, porém cada consórcio é responsável exclusivamente por seu lote. Estas ligações servem apenas para o bom andamento da obra. Como o Consórcio 1 ganhou a concorrência dos lotes 1 e 2 da obras e estes são significativamente maiores que o lote 1 , este consórcio por meio de ligações não disponibilizadas a acesso público, repassa algum dos serviços ao Consórcio 2. Estes dados foram coletados em entrevistas e demonstraram formação de uma rede pré estabelecida por todas as empresas dos dois consórcios . Esta rede atua em vários setores da construção civil. 
Dentro dos dados encontrados, podemos extrair as seguintes ligações:

Ligação 1 - Contrato de formação do Consórcio 1;

Ligação 2 - Contrato de formação do Consórcio 2;

Ligação 3 - Contrato de prestação de serviços entre o Consórcio 1 e suas empresas subcontratadas.;

Ligação 4 - Contrato de prestação de serviços entre o Consórcio 2 e suas empresas subcontratadas;

Ligação 5 - Relacionamento informal entre as empresas dos dois consórcios.

\subsubsection{Elementos "Fluxos"}

Os fluxos são elementos com total vínculo aos elementos ligações. Foram encontrados os dois tipos de fluxos dentro da obra, os intangíveis e os tangíveis. Os fluxos tangíveis foram encontrados principalmente entre as empresas do consórcio as empresas subcontratadas. Como visto, as empresas subcontratadas também atuam com Turn-Key, ou seja, seu produto final é entregue ao contratante pronto para uso. Os fluxos tangíveis são os materiais que as empresas subcontradadas agregam a obra. Na obra foram encontrados outros tipos de fluxo, os fluxos intangíveis que se estabeleciam entre todas as empresas dos consórcios. Os fluxos intangíveis são os acordos, contratos e informações que não são agregados físicos a obra.

Fluxo 1 - Fluxo tangível (materiais).

Fluxo 2 - Fluxo intangível (informações)

\subsection{Desenho da rede utilizando EKD}

A partir da definição dos elementos da rede no item 6.2, foi feita a configuração da mesma com o uso da metodologia EKD. Na figura 12 é mostrada a rede formada pelas empresas participantes dos dois consórcios. Esta rede pode ser considerada uma rede flexível, porém as empresas, principalmente as de construção civil, já formaram anteriormente ou atualmente alguns outros consórcios. Das empresas contratadas para obra do metrô, algumas delas possuem concessão de estradas conjuntamente e outros negócios em parcerias. 


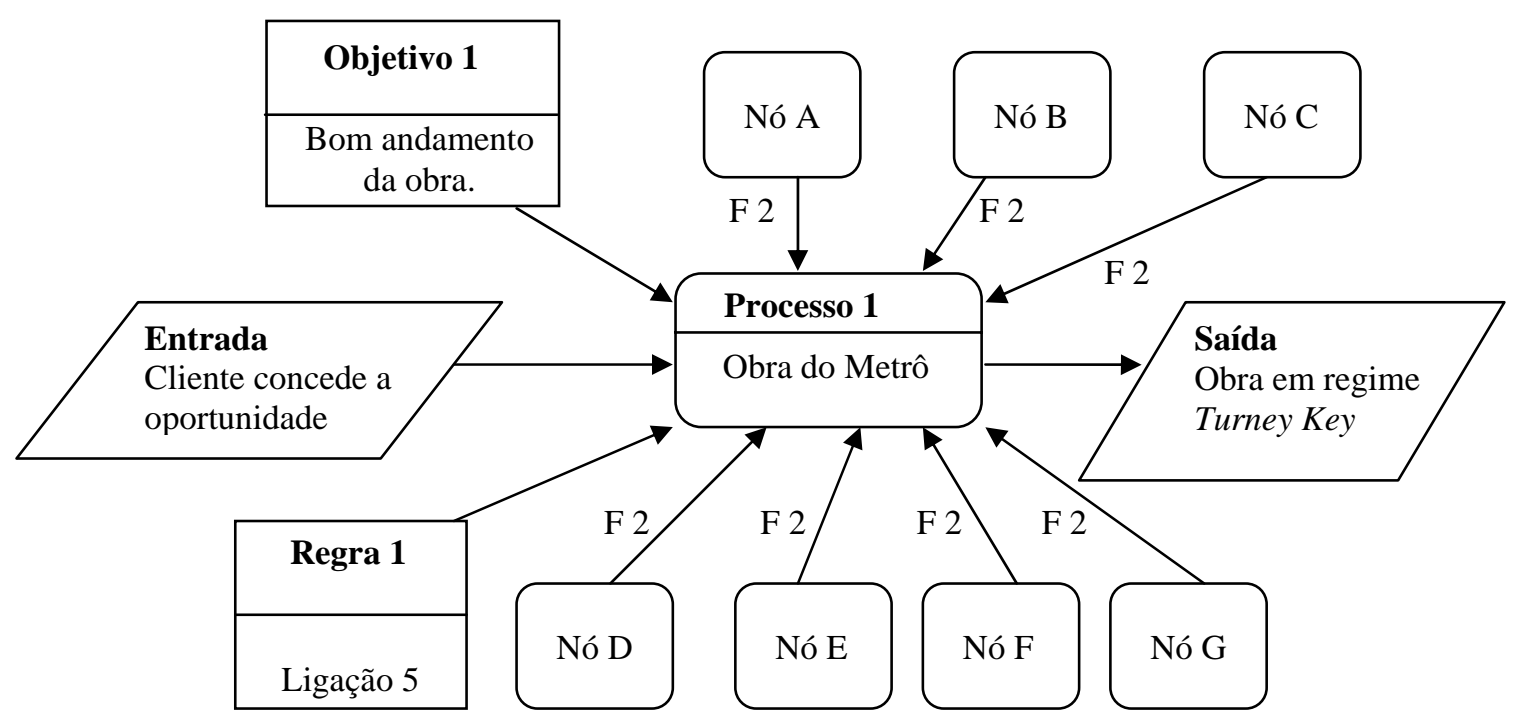

F 2 - Fluxo 2

Figura 11 - Rede formada pelos dois consórcios participantes da execução da obra

Expandindo a figura 12 tem-se a figura 13 que demonstra a disposição das empresas no Consórcio 1. A Empresa A é a líder do Consórcio 1, mas as Empresas A, B, C e D trabalham juntas e possuem independência dentro de toda a rede.

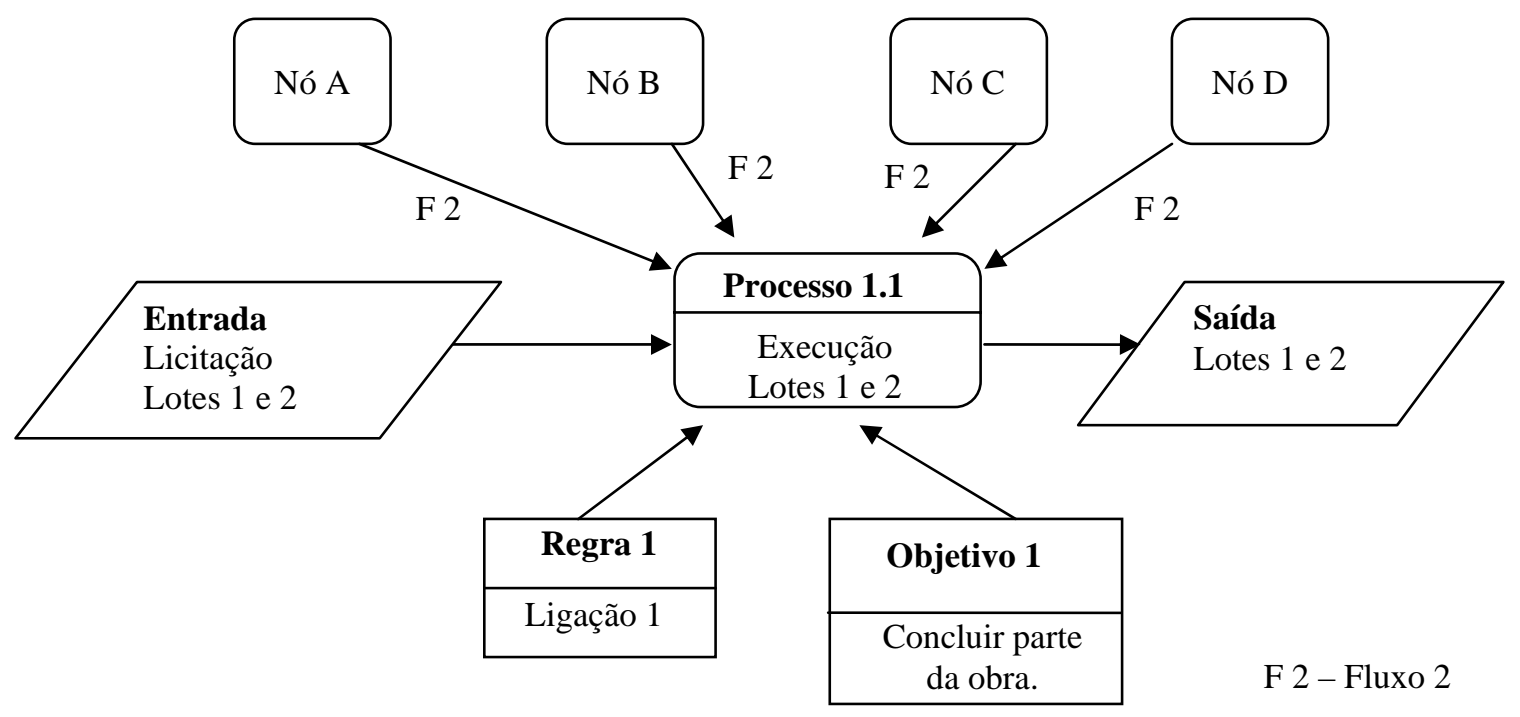

Figura 12 - Rede do Consórcio 1

A figura 14 demonstra a disposição das empresas dentro do Consórcio 2. A empresa líder é a Empresa E, mas as três empresas também mantêm sua individualidade dentro da rede. 


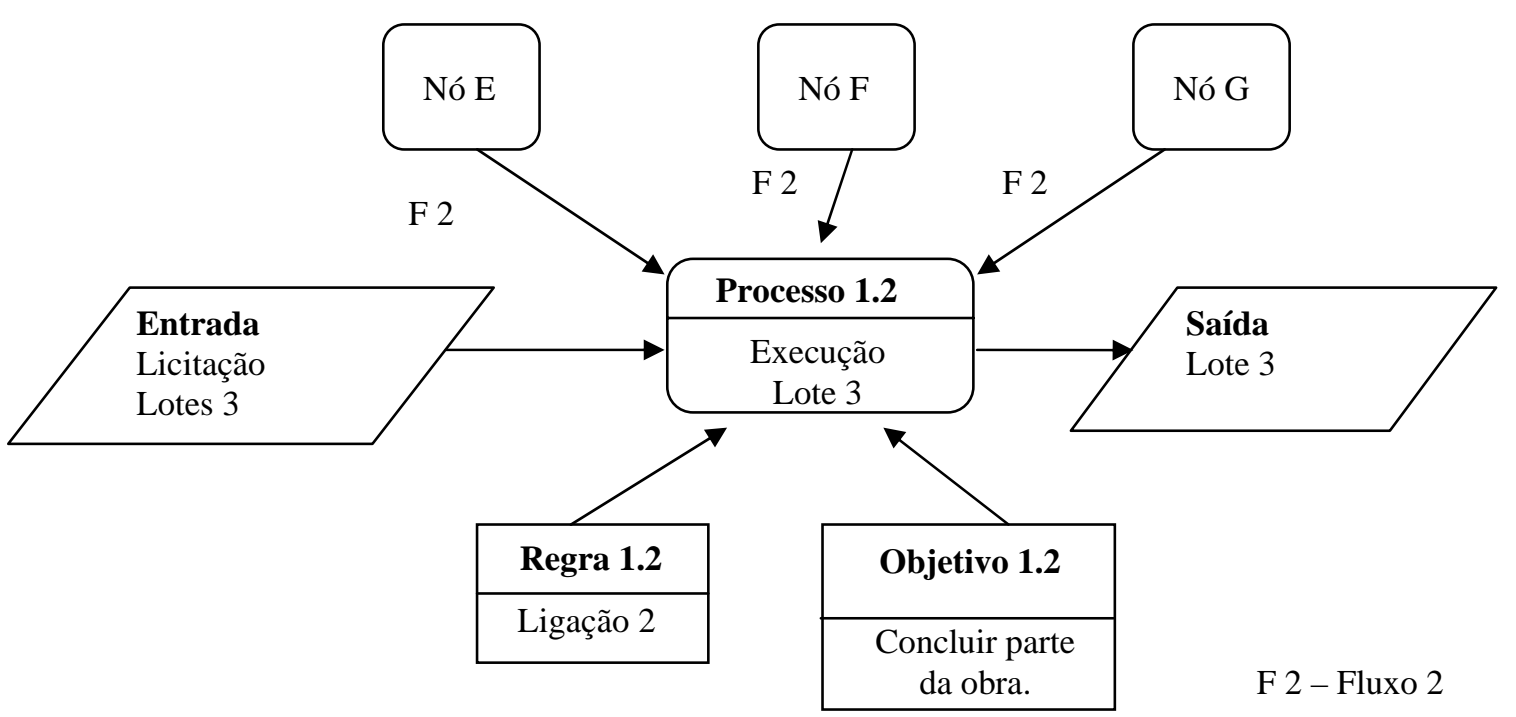

Figura 13 - Rede do Consórcio 2

Expandindo as figuras 13 obtém-se as figura 15 e 16, nas quais temos todas as "posições" com seus “nós” relacionados. A relação entre as posições e os nós foi estabelecida de acordo com a competência essencial de cada nó. 


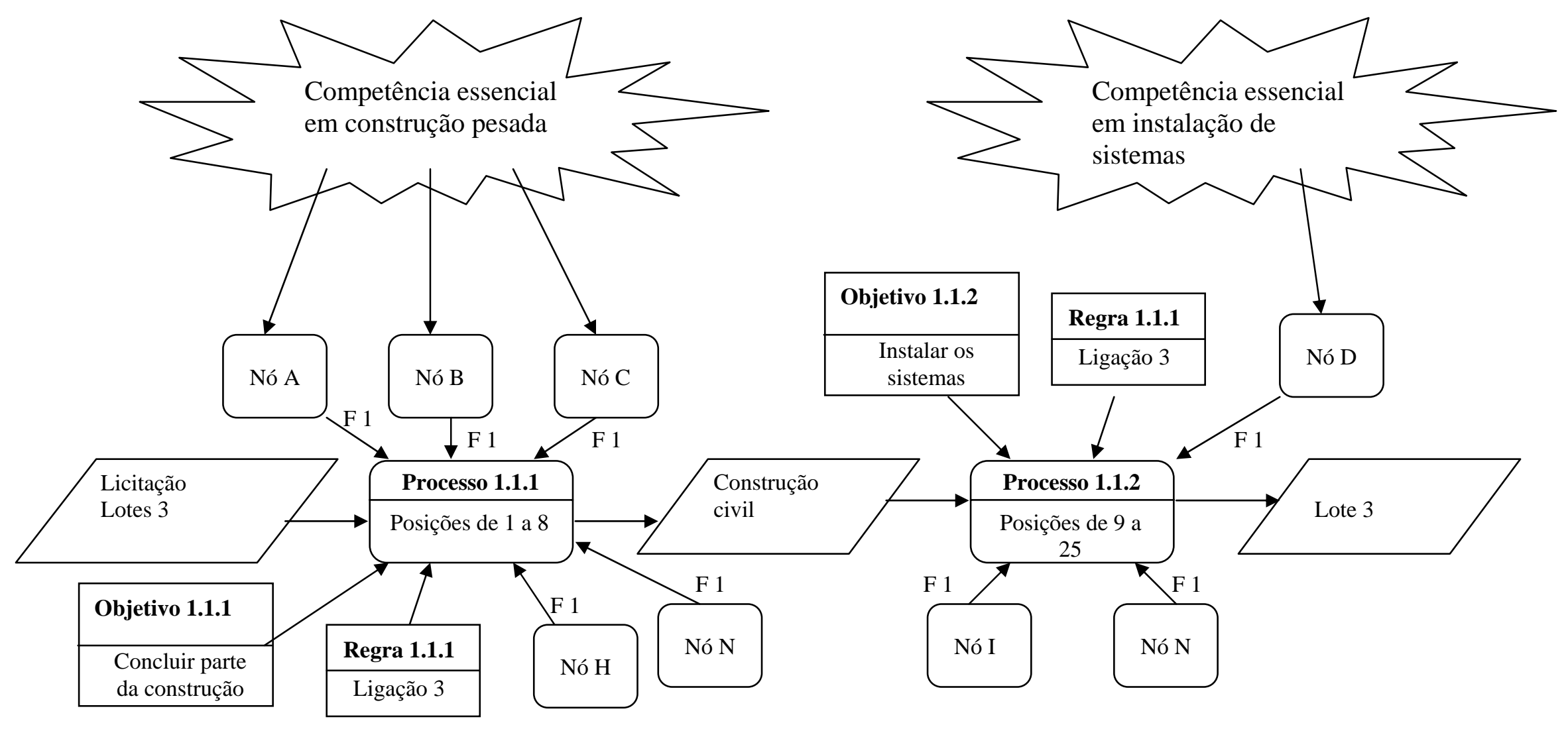

F 1 - Fluxo 1

Figura 14 - Localização das competências essenciais dentro da rede. 


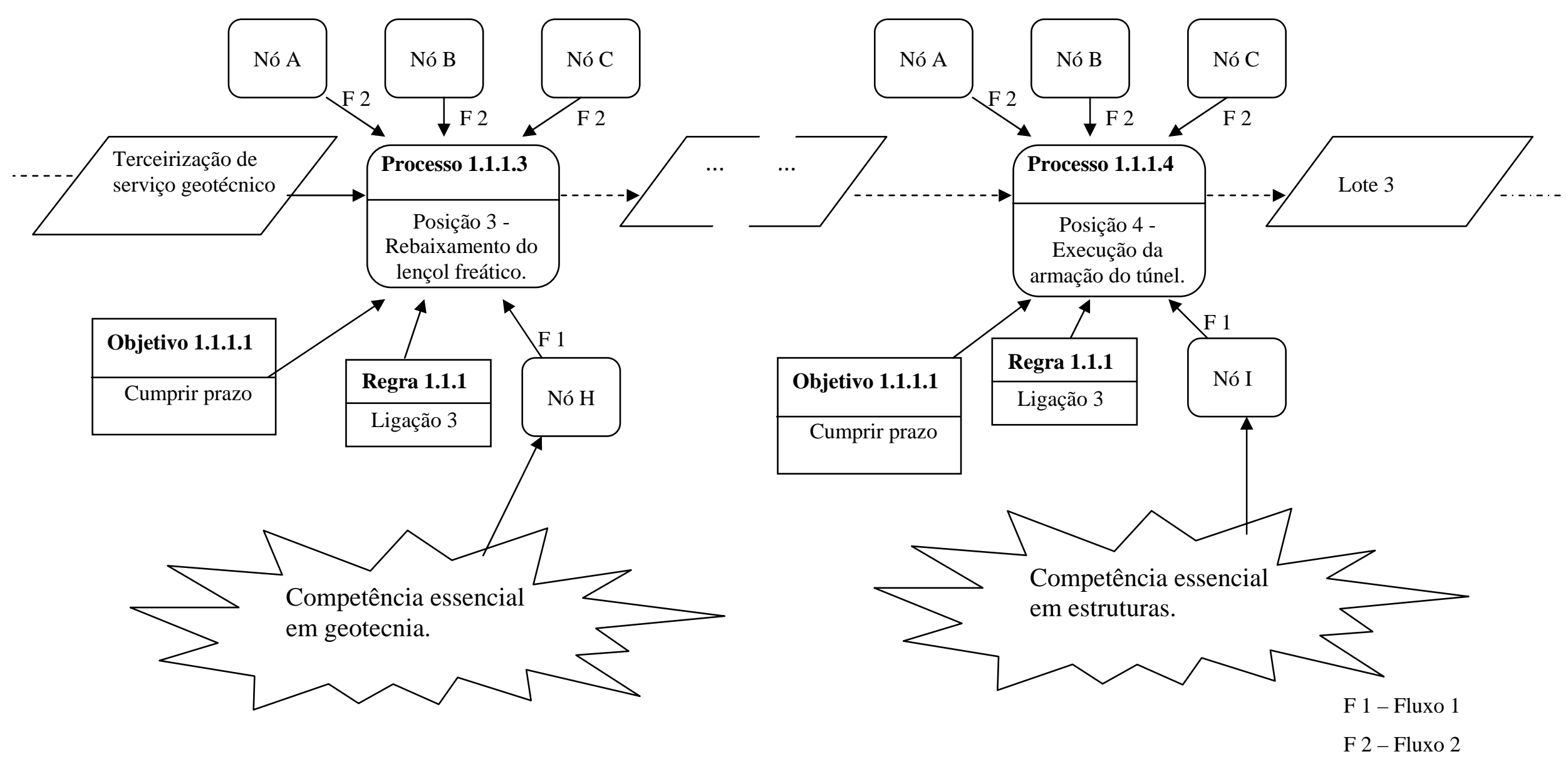

Figura 15 - Localização das competências essenciais das empresas subcontratadas dentro da rede. 


\subsection{Sistematização do processo de identificação de competências essenciais}

Partindo da idéia da figura 6, a qual mostrou a percepção de Javidan (1998) de como podem ser encadeados recursos, capacidades, competências, e competências essenciais fez-se a sistematização da identificação das competências essenciais. Em resumo, os recursos são as bases para as capacidades. As capacidades fazem um papel mais importante realizando os objetivos empresariais de uma empresa. Essas capacidades são fundamentais e é altamente provável que o coletivo em operação destas capacidades forme as competências de uma companhia. As competências essenciais são por fim, por natureza, flexíveis e dinâmicas, contituindo uma parte integrante da aprendizagem organizacional.

Baseado nestas definições de Javidan (1998), foi proposta uma maneira estruturada para identificar competências essenciais. Essencialmente, o processo consiste em quatro passos:

- Passo 1: determinação dos recursos;

- Passo 2: identificação de capacidades;

- Passo 3: determinação de competência;

- Passo 4: identificação de competência essencial.

Além da proposição de Javidan acrescenta-se um passo 5 sobre a combinação de competências para a formação da rede.

Nos tópicos seguintes é descrito, passo a passo, o procedimento de como implementar este processo, ou seja, como podem ser identificadas as competências essenciais, com base na maneira com que foram analisadas e identificadas as competências essenciais do estudo de caso.

\subsubsection{Passo 1: Determinação dos recursos}

A determinação dos recursos é um passo totalmente quantitativo. Dentro desta fase serão analisadas as empresas de acordo com seus recursos físicos, como maquinários e prédios, recursos humanos, como quantidade de funcionários de acordo com suas especialidades, e recursos financeiros analisados através de ativos líquidos, linhas de créditos e outros meios financeiros das mesmas. Estes recursos são demonstrados em históricos e currículos disponibilizados em obras anteriores ou até mesmo em atuais propostas das quais as empresas participam. Corroborando com Banerjee (2003), podem ser coletados os recursos físicos (por exemplo, matérias-primas, equipamento, dom financeiro etc.) e recursos humanos (por exemplo, engenheiros, administradores etc). 
Com a utilização de recursos financeiros, os recursos físicos podem ser fabricados e comercializados entre as empresas. Uma combinação destes recursos pode gerar uma capacidade e estas são analisadas em um próximo passo.

\subsubsection{Passo 2: Identificação de Capacidades}

Identificar as capacidades é uma etapa crucial ao sucesso do processo; é o passo mais importante. O processo de identificação pode envolver a análise das atividades empresariais fundamentais como administração geral, construção, produção de equipamentos, engenharia etc. As capacidades podem ser coletadas segundo a definição de Hafeez, Zhanga e Malak (2002), após a analise dos recursos. De modo geral capacidades são as atividades que as empresas podem realizar com seus recursos. A capacidade se refere à habilidade de uma organização em explorar os recursos. (JAVIDAN, 1998).

Embora o conhecimento, como a experiência dos engenheiros da companhia, possa ajudar nesta fase, deve-se confiar em medidas físicas, humanas e financeiras puramente, sem suas conseqüentes implicações. Não são as capacidades que ajudam a gerar lucro e não são estas capacidades que vão gerar os líderes de mercado dentro do setor. Por exemplo, as capacidades fundamentais das empresas analisadas, como a construção de pontes ou construção de trens, garantem às mesmas a possibilidade de realização de determinado serviço. As capacidades de uma empresa não garantem e, ainda, não geram margem de lucro, fato eliminado na análise neste passo.

As capacidades podem ser comercializadas a ponto de serem compradas pelas firmas. As empresas podem contratar engenheiros, comprar equipamentos para possuir capacidades iguais aos das empresas A ou B do estudo de caso. Isto não implica que elas irão possuir as mesmas competências das empresas estudadas, fato que deve ser analisado em um próximo passo.

Foi primordial identificar capacidades dentro de cada área funcional das empresas dos consórcios. Estas capacidades são percebidas como as forças da companhia e crucial aos objetivos empresariais das mesmas. O processo de identificação foi restringido a analisar atividades ao nível operacional. Inicialmente é gerada uma lista de capacidades com consulta ao que foi exigido na licitação da obra. De acordo com o percebido no desenho da rede foi priorizada a importância do serviço da empresa para o negócio. 


\subsubsection{Passo 3: Determinação de Competências}

Neste passo, avalia-se a integração de capacidades em atividades empresariais executadas na obra. As competências são as capacidades que possuem as características que dão, as empresas condições para alcançarem suas metas (RITTER e GEMÜNDEN 2003).

Como explicado anteriormente, esta integração de capacidades é entendida como a flexibilidade operacional de uma companhia e avaliada medindo a integração de produção, função e ganhos das operações das empresas. As competências das empresas são avaliadas em uma balança no qual as capacidades tornam-se ganhadoras de vantagens competitivas. As capacidades são empregadas em várias funções demonstradas durante o negócio. Por exemplo, nas empresas que formaram o consórcio, suas competências já eram encontradas em várias outras oportunidades de negócio. É interessante notar que os recursos e as capacidades das empresas de construção civil são as mesmas em todas as empresas porém, como demonstrado, as competências das empresas se diferenciam em quantidade e especialidades. Algumas das empresas possuem especialidades como a Empresa G que tem competência em construção de estradas. Isto ocorre, porque nesta fase de avaliação já é considerada a experiência particular de cada empresa. O principal requisito de sua avaliação é o reconhecimento do cliente, somando-se às capacidades uma vantagem competitiva.

As competências são atividades que podem ser desenvolvidas pelas empresas. Claramente, é muito provável que atividades com essa característica sejam as competências da empresa. Não mais que algumas das capacidades são competências e algumas competências podem ser simultaneamente raras, inimitáveis, e garantam a sustentação da empresa, em competição. Passa-se assim para um próximo passo no qual são analisadas as competências que são as competências essenciais.

\subsubsection{Passo 4: Determinação de Competências Essenciais}

Nesta fase são analisadas as principais características propostas por Hamel e Prahalad (1990), nas quais as competências têm que passar pelos seguintes testes: o reconhecimento do cliente, a diferenciação entre os concorrentes e a perspectivas de inovação e desenvolvimento. A perspectiva e a satisfação do cliente são demonstradas na consistência da marca da empresa que se torna referência entre as empresas do setor. As principais medida usadas na análise é a de inovação e diferenciação, entre concorrentes, com a introdução de novos produtos das empresas, produtos estes difíceis de serem copiados por empresas concorrentes. Em estudo de caso todas as empresas passaram por esse teste, como já mencionado. 
As competências essenciais transformam as empresas em referências no do setor o que fazem que elas mesmas ditem as regras competitivas. Como exemplificado, as empresas do consórcio possuem várias capacidades, muitas competências iguais, porém desenvolveram e inovaram suas competências a ponto de transformarem essas competências em competência essencial e as utilizarem na realização da obra da - Linha 4 do metrô de São Paulo.

\subsubsection{Passo 5: Combinação de Competências Essenciais}

As competências essenciais demonstram a flexibilidade necessária à realização de qualquer oportunidade do setor. Essas competências essenciais foram usadas como estratégia para definir quais empresas vão atuar em cada "posição” da obra do metrô. A “posição” pode ser preenchida pela competência analisada, que define o “nó” da rede. As empresas ou "nós” podem ser prontamente transferidas e, também, reorganizadas para desenvolver negócios no futuro. Corroborando a visão de Bogner, Thoma e McGee (1999), a distribuição das competências essências, dentro da obra do metrô, mostrou-se bastante necessária. A partir das competências essenciais das empresas são desenvolvidos os produtos essenciais que, juntos, irão formar a linha 4 do metrô de São Paulo (figura 18).

Por mais que as ligações entre as competências essenciais e a obra do metrô não sejam diretas, as competências essenciais são as características que sustentam a criação de tecnologias e processos essenciais que, por fim, geram a construção da obra.

Confirmando a idéia de Hamel e Prahalad (1995), as empresas concentraram-se em suas competências essenciais e utilizaram seus recursos e capacidades para o processo, assim, criaram vantagem competitiva para a efetivação da construção do metrô.

Na visão de Hamel e Heene, (1994) as empresas também podem ser colocadas em níveis de abstração de competências essenciais como na figura 7. Assim, o produto final pode ser considerado feito por uma meta competência essencial. Essa meta competência essencial está contida na rede. Neste caso, no nível mais inferior são colocadas as habilidades das empresas, habilidades essas que são as competências das empresas. Logo acima são consideradas as competências essenciais que vão ser utilizadas por cada empresa participante da rede. No nível mais superior é colocada a meta competência essencial, ou seja, a união de todas as competências que propicia a realização de um determinado trabalho. O exemplo dos níveis de abstração da obra do metrô está representado na figura 17. 


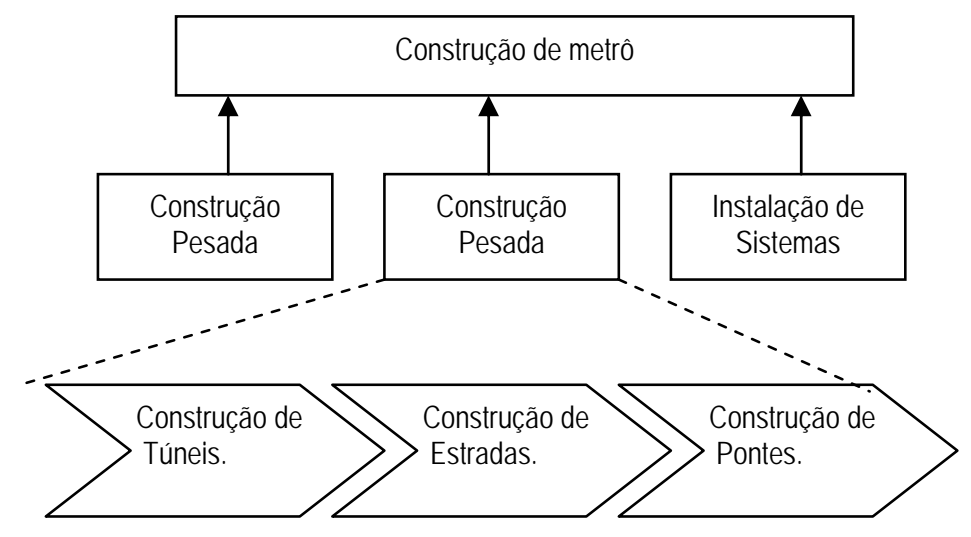

Figura 16 - Níveis de abstração de competências essenciais na obra do metrô.

A rede formada para a construção do metrô confirmou o ciclo de vida colocado por Goranson (1999). Em uma primeira etapa foi identificada a oportunidade através da licitação que foi aberta pela Companhia Metropolitana de São Paulo. As empresas interessadas em participar desta concorrência buscaram parceiros para atuar nesta oportunidade, a fim de aumentarem suas vantagens competitivas. Assim, foram formados os consórcios pela empresas, designando a cada sócio uma posição dentro da rede a partir das obrigações encontradas na licitação. Ao final da disputa as empresas colocaram em funcionamento a rede e, por fim, fizeram uma reconfiguração para dividirem algumas das obrigações e melhorar a configuração da rede para o bom andamento da obra. Após o término da obra haverá a dissolução da rede, mas essa dissolução não impede que as empresas voltem a formar outras redes para o atendimento de outras oportunidades. Entre as empresas formadoras desta rede verificou-se uma grande união por meios informais que levam as mesmas a estar sempre juntas para várias oportunidades.

Como síntese dos aspectos abordados até o momento, a Figura 18 sintetiza a reunião e distribuição das competências essenciais na obra do metrô. 


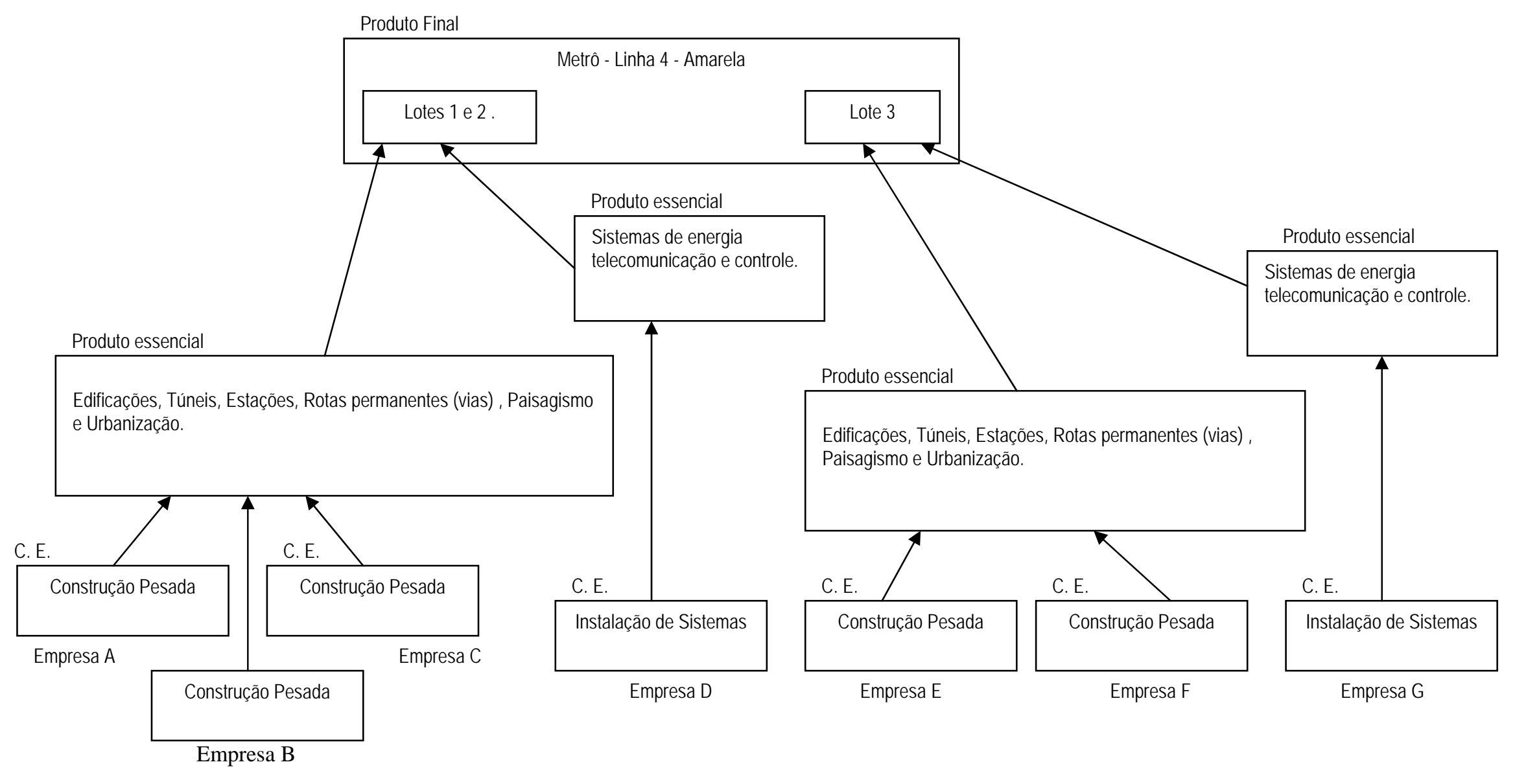

- C. E. - Competência Essencial.

Figura 17 - Reunião e distribuição das competências essenciais na obra do metrô 


\subsection{Considerações finais}

Em estudo de caso, foi verificado que, na busca de parcerias para a formação da rede, o principal elemento analisado foi a "posição" de cada elemento "nó” dentro da rede. A partir das posições foram identificadas as competências essências necessárias, agrupados os nós que possuem essas competências para a formação dos consórcios e, por fim, foi feita a formação da rede. Definiu-se, então, que o foco das competências essenciais está no elemento morfológico "posição” da rede e que a competência essencial é uma característica de cada elemento "nó". Com o intuito de demonstrar a formação da rede por meio da identificação das competências essenciais foi desenvolvida uma sistematização para locar as empresas ou nós em suas posições.

As empresas usaram as competências essências para formar suas estratégias, colocaramnas em uma rede de empresas e ganharam uma forte base da competitividade para a disputa da concorrência e ganharam a licitação. 


\section{CONCLUSÕES}

O trabalho desenvolveu uma sistematização para avaliar as competências essenciais necessárias para formação da rede de empresas capaz de possibilitar algum diagnóstico das empresas, dentro de um agrupamento de empresas da construção civil. A sistematização possibilita a indicação de empresas para fazer parte da rede e aumentar a competitividade daquelas que procuram participar de uma certa oportunidade.

O objetivo de formação das redes de empresas e o objetivo de mostrar como são estruturadas as redes de empresas na construção civil, foi obtido com o levantamento de estudos sobre redes no capítulo 2 e com a adaptação do conceito de redes de empresas em consórcios da Construção Civil no capítulo 6. Para isto, no estudo de caso abordou-se, dois grandes consórcios formados por grandes empresas reconhecidas dentro do setor. A análise do caso concreto foi a partir dos consórcios para a obra do metrô - Linha 4 Amarela - de São Paulo que está sendo construída.

Embora seja uma formação de rede específica, a união dos consórcios mostrou-se a mesma do recorte analítico de rede de empresas.

A identificação de competências essenciais para a formação das redes foi demonstrada com a análise das competências do estudo de caso. O resultado de estudo de caso no capítulo 6 demonstrou que as empresas participantes do consócio obtiveram vantagens competitivas através da utilização de competências essenciais para a busca de parcerias na formação dos consórcios.

A identificação das competências essenciais para criação de redes entre as empresas do setor, foi cumprida pela análise de competências das empresas do estudo de caso no capítulo 5 e a conseqüente sistematização da mesma no capítulo 6. Como dito, desenvolveu-se uma sistematização que possibilita um diagnóstico das competências essenciais das empresas para o agrupamento em forma de rede de empresas da construção civil.

Além da demonstração concreta vista em estudo de caso, a metodologia de pesquisa mostrou sua boa aplicação prática, pois possibilitou completa visão da competitividade das empresas dos consórcios, seus principais objetivos e, ainda, as possibilidades de cooperação. Mostrou também alto grau de competências essenciais com muita consistência pois, na prática 
foi avaliada a performance das empresas dentro da competitividade e vantagens por meio de intenções de cooperação destas competências. Possibilitou, ao mesmo tempo, avaliar as competências essenciais de cada empresa e a formação da rede de empresas.

As empresas do setor da Construção Civil ao trabalharem associadas, com suas competências essenciais, obtêm vantagens competitivas e melhoram seu desempenho na produção para competir em licitações de grandes obras. É possível reunir um número de competências essenciais e trabalhar para melhorar a competitividade com base na cooperação.

A comparação das competências essenciais facilita a união das empresas antes e após a adoção de um esquema cooperativo, ou seja, na formação e no gerenciamento de redes de empresas.

Percebe-se que para o processo de execução de obras civis, a inserção de redes e a adoção de procedimentos de identificação de parcerias através de competências essenciais, poderão ser pontos estratégicos para essas empresas. O setor construção civil mostrou muita adequação ao trabalho realizado. A maioria das oportunidades do setor com suas necessidades exigidas são muito grandes em comparação as possibilidades de cada empresas de construção.

Pode-se considerar que é adequado identificar as empresas sob o conceito de “competências essenciais”. As empresas utilizam suas competências essenciais para a formação da rede. Desta maneira, sugere-se a utilização do procedimento para outros subsetores da construção civil e outras empresas para que este seja refinado, contribuindo para a sua generalização.

Esse trabalho complementa a pesquisa desenvolvida em grupo dando continuidade às pesquisas de viabilização do planejamento e controle da produção em rede e definição dos requisitos organizacionais para a formação e gerência de redes de cooperação na construção civil.

Deve-se considerar, no entanto, que apesar das obras de construção civil possuírem diversas características preconizadas pela teoria de redes, os profissionais do setor desconhecem o seu conteúdo. Isso dificulta a disseminação dos conceitos necessários para que, efetivamente, as obras funcionem como uma rede de cooperação.

No caso específico da obra analisada, observa-se que a modalidade de contrato “consórcio” possui diversos mecanismos legais para garantir que as relações de mercado possuam uma estruturação hierárquica que garanta uma clara identificação das responsabilidades e requisitos mínimos dos participantes na obra. A situação mais característica está na relação de subempreita no qual é o contratante que responde por quaisquer prejuízos causados pelos seus subcontratados. Isso demonstra, claramente, que os 
subcontratados são vistos como um meio de responder rapidamente a uma contingência da obra, mas que não há responsabilidade atribuída pelo serviço.

Há, neste caso, uma clara reafirmação das relações hierárquicas verticais em detrimento da visão mais horizontal da cooperação, caso em que os riscos e oportunidades são distribuídos e os ganhos coletivos podem ser maiores. Isso ocorre porque as subempreiteiras entram no processo após a etapa de licitação. A questão poderia ser vista sob outro aspecto, se as empresas subcontratadas participassem também do processo de licitação a partir da indicação das empreiteiras, com demonstração de capacidade técnica.

Como sugestão para trabalhos, o próximo passo é desenvolver modelos de dados para a viabilização das redes de cooperação entre empresas de construção civil a partir das competências essenciais identificadas para a obra. Este modelo permitiria identificar a natureza dos fluxos de recursos entre as empresas, bem como estabelecer critérios para a definição dos procedimentos de troca de informações dos fluxos intangíveis. 


\section{REFERÊNCIAS BIBLIOGRÁFICAS}

AMATO NETO, J. (2000). Redes de cooperação produtiva e clusters regionais: oportunidades para as pequenas e médias empresas. 1. ed. São Paulo: Atlas, Fundação Vanzolini.

BAKER, J. C.; MAPES, J.; NEW, C. C.; SZEJCZEWSKI, M. A. (1997). Hierarchical model of business competence. Integrated Manufacturing Systems, (UK). v. 8, n. 5, p. 265 - 272.

BALESTRIN, A.; VARGAS, L. M. FAYARD, P. (2003). Contexto favorável à criação de conhecimento organizacional: o caso de uma rede de PMEs no sul do Brasil Disponível em: $<$ http://unpan1.un.org/intradoc/groups/public/documents/CLAD/clad0047519.pdf> Acesso em 03 jun. 2004.

BANERJEE, P. (2003). Resource Dependence and Core Competence: Insights from Indian. Software Firms, Technovation, v. 23, p. 251-263

BELUSSI, F.; ARCANGELI, F. (1998). A typology of networks: flexible and evolutionary firms. Research Policy. v. 27, p. 415-428.

BERNARDES, M. M. e S.; FORMOSO, C. T. (2000). Implantação de um modelo de planejamento da produção em uma empresa de construção de pequeno porte. In; 8., Encontro Nacional de Tecnologia do Ambiente Construído (ENTAC). Anais... Salvador.

BOGNER, W. C.; THOMAS, H.; McGEE, J. (1999). Competence and competitive advantage: towards a dynamic model. British Journal of Management. Dec, v. 10, n. 4, p. 275.

BRASILEIRO NETTO, J.; FREITAS, A. A. F.; NOVAES, L. N. S. (2003). Alianças estratégicas para inovações na construção civil em fortaleza - o caso inovacon. In: 3., Simpósio Brasileiro de Gestão e Economia da Construção (SIBRAGEC). Anais...UFSCar, São Carlos. 
BRITTO, J. (2000). Elementos estruturais e mecanismos de operação das redes de firmas: uma discussão metodológica, In: 5., Encontro Nacional de Economia Política da SEP Sociedade Brasileira de Economia Política, Anais... Fortaleza.

BRITTO, J. (2002a). Cooperação industrial e redes de empresas. In: KUPFER, D.; HASENCLEVER, L., org's. Economia industrial: fundamentos teóricos e práticos no Brasil. Rio de Janeiro: Campus, p. 345-386.

BRITTO, J. (2002b). Elementos estruturais e conformação interna das redes de firmas: desdobramentos metodológicos, analíticos e empíricos. In: 7., Encontro Nacional de Economia Política da SEP - Sociedade Brasileira de Economia Política, Anais... Universidade Federal do Paraná - Curitiba.

CÂNDIDO, G. A. (2001). Fatores críticos de sucesso no processo de formação, desenvolvimento e manutenção de redes interempresariais do tipo agrupamento industrial entre pequenas e médias empresas: um estudo comparativo de experiências brasileiras. Tese (Doutorado) - Universidade Federal de Santa Catarina. Florianópolis.

CARDOSO, F. F. et all.(2000). Desenvolvimento e gestão da cadeia de fornecedores na construção de edifícios. Disponível em:

$<$ http://docentes.pcc.usp.br/fcardoso/ArtigoLeanConstruction.pdf> . Acesso em 9 jun. de 2004;

CARDOSO, F. F.; FILIPPI, G. A. ; PEREIRA, S. R. (2000). Micro e pequenas empresas fornecedoras de mão-de-obra da construção civil: caracterização, organização e estratégias. In: 20. Encontro Nacional De Engenharia De Produção. Anais... São Paulo-SP

CASAROTTO, R. M. (2002). Redes de empresas na indústria da construção civil: Definição de funções e atividades de cooperação. Tese (Doutorado) - Universidade Federal de Santa Catarina. Florianópolis.

CERVO, A. L.; BERVIAN, P. A. (1983). Metodologia científica. São Paulo: McGraw-Hill do Brasil.

CHECKLAND, P. B. (1983). Systems thinking, systems practice. New York: Jonh Wiley \& Sons. 
CORRÊA, G. N. (1999). Proposta de integração de parceiros na formação e gerência de empresas virtuais. Tese (Doutorado). Escola de Engenharia de São Carlos - Universidade de São Paulo. São Carlos.

CUKIERMAN, Z. S. (1993). O modelo PERT/CPM aplicado a projetos. Rio de Janeiro: Qualitymark Editora Ltda.

DABOUB, A. J. (2002). Strategic alliances, network organizations, and ethical responsibility. S.A.M. Advanced Management Journal. v. 67, n. 4, p. 40.

DANE, F.C. (1990). Research methods. Belmont: Brooks/Cole.

ESPRIT (2004). The European Strategic Program for Research in Information Technologie. Disponivel em: <http://www.cordis.lu/esprit/home.html>. Acesso em 01 jun. 2004.

FABRICIO, M. M.; SILVA, F. B.; MELHADO, S. B. (1999). Parcerias e estratégias de produção na construção de edifícios. In: 19., Encontro Nacional de Engenharia de Produção ENEGEP, Anais... Rio de Janeiro.

Fine, C. and D. Whitney (1996), Is the Make-Buy Decision Process a Core Competence?. IMVP Working Paper, Massachusetts Institute of Technology.

FLEURY, A. C. C.; FLEURY, M. T. L. (1997) Aprendizagem e Inovação Organizacional: as experiências de Japão, Coréia e Brasil. São Paulo: Atlas.

FLEURY, A. C. C.; FLEURY, M. T. L. (2003). Estratégias competitivas e competências essenciais: perspectivas para a internacionalização da indústria no Brasil. Gest. Prod. [online]. V.10, n.2, p.129-144 Disponível em:

$<$ http://www.scielo.br/scielo.php?script=sci_arttext\&pid=S0104530X2003000200002\&lng=pt\&nrm=iso> Acesso em 14 mai. 2004.

FORBES, P. M. (1991). Marketing management: developing a core competence. National Petroleum News. Chicago: May. v. 83, n. 5, p. 59.

GALBRAITH, JR et al., (1995). Organizando para competir no futuro. São Paulo: Makron Books. 
GORASON, H. T. (1999). The agile virtual enterprise: cases, metrics, tools. Westport, Conn.: Quorum Books.

GORMAN, P.; THOMAS, H. (1997). The Theory and Practice of Competence-based Competition. Long Range Planning. v. 30, n. 4, p. 615-620.

GOULART, C. P. (2000). Proposta de um modelo de referencia para planejamento e controle da produção em empresas virtuais. Dissertação de mestrado. Escola de Engenharia de São Carlos, Universidade de São Paulo, São Paulo.

GRANDORI A.; SODA, G. (1995). Inter-firm networks: antecedents, mechanisms and forms. Organization Studies. v. 16, n. 2, p. 183-214

GRILO, L. M.; MELHADO, S. B. (2002). Novas formas de contratação e organização dos empreendimentos no segmento de construção de edifícios para terceiros. In: 9., Encontro nacional de tecnologia do ambiente construído. ENTAC, Foz do Iguaçu.

GRILO, L. M.; MELHADO, S. B. (2003a). A integração entre os agentes do processo de produção e o desempenho da indústria da construção. In: 3., Workshop Brasileiro de Gestão do Processo de Projeto. Belo Horizonte.

GRILO, L. M.; MELHADO, S. B. (2003b). Alternativas para a melhoria na gestão do processo de projeto na indústria da construção de edifícios. In: 3., Workshop Brasileiro de Gestão do Processo de Projeto. Belo Horizonte.

HAFEEZ, K.; YANBING Z.; MALAK, N. (2002). Core competence for sustainable competitive advantage: a structuredmethodology for identifying core competence. IEEE Transactions on Engineering Management. v 19, n 1.

HAMEL,G., PRAHALAD, C.K (1995). Competindo pelo futuro: estratégias inovadoras para obter o controle do seu setor e criar os mercados de amanhã. 10.ed. Rio de Janeiro: Campus.

HAMEL,G.; HEENE, A. (1994) Competence Based Competition. Chichester: John Wiley \& Sons.

HARVEY, M.; LUSCH, R. (1997). Protecting the core competencies of a company: Intangible asset security, European Management Journal, Aug., v. 15, n. 4, p. 370-380. 
HIMES P. E. (1995). Partnering in the construction process: the method for the 1990s and beyond. Emerald Group Publishing Limited. v. 13, n. 6, p. 13-15.

JAVIDAN, M. (1998). Core competence: What does it mean in practice? Long Range Planning, v. 31, n.1, p. 60-71.

LAMPEL, J. (2001). The core competencies of effective project execution: the challenge of diversity. International Journal of Project Management. v. 19, p. 471-483.

LAUMANN E. O.; GALASKIEWICZ J.; MARSDEN P. V. (1978). Community Structure as Interorganizational Linkages. Annual Review of Sociology. Aug., v. 4, p. 455-484.

Leão, L. C. G. (2000). Uma contribuição ao planejamento de consórcio de empresas. Dissertação (Mestrado) - Faculdade de Economia, Administração e Contabilidade, Universidade de São Paulo, São Paulo.

LINTON, J.; WALSH, S.(2002). The Measurement of Technical Competencies. Journal of High Technology Management Research,v.13 p.1-24

MACHADO, R. L.; HEINECK, L. F. M. (2003). Um novo modelo de PCP para o setor da construção civil. Disponível em:

<http://www.ucg.br/Institutos/nucleos/nupenge/pdf/Ricardo_Machado_II.pdf> Acesso em 30 de jun. de 2004.

MAJOR, E., ASCH, D.; CORDEY-HAYES, M. (2001). Foresight as a core competence. Futures, v. 33,. p. 91-107

MARTINS, S. P.(2000). A terceirização e o direito do trabalho. 4. ed. São Paulo: Atlas.

NASSIMBENI, G. (1998). Network Structures and Co-ordination Mechanisms A Taxonomy. International Journal of Operations \& Production Management, v.18, n.6, p. 538-554.

NISEMBAUM, H. (2000). A competência essencial. São Paulo, ed. Infinito.

PÁDUA, S.I.D. (2001). Investigação do processo de desenvolvimento de software a partir da Modelagem Organizacional, enfatizando regras do negócio. Dissertação (Mestrado) Escola de Engenharia de São Carlos, Universidade de São Paulo, São Carlos. 
PETTS, N. (1997). Building growth on core competences: A practical approach. Long Range Planning, v. 30, n. 4, p. 478.

PIDD, M. (1997). Metodologia de sistema soft. In: Modelagem empresarial: ferramentas para tomada de decisão. São Paulo: Bookman Companhia Editora. p. 118-138.

PORTER, M. E. (1992). Vantagem competitiva: Criando e sustentando um desempenho superior. Rio de Janeiro: Campus.

PRAHALAD, C. K. (1998). Entrevista: em busca do novo. Revista HSM Management. n. 7, Mar - Abr 1998.

PRAHALAD, C. K.; HAMEL, G. (1998). A Competência Essencial da Corporação. In: Montgmery, C.; Porter. M. Estratégia: A Busca da Vantagem Competitiva. 3. ed. Rio de Janeiro: Campus p. 293-316.

RAO C. B. (2002). India Inc: Core (in) competence?. Business Line. Financial Daily from the hindu group of publications. Disponivel em:

<http://www.blonnet.com/2002/08/06/stories/2002080600060800.htm> Acesso em 20 mai. 2004.

REDECOOP (2004). Redes de cooperação e gestão do conhecimento. Disponível em: <http://www.prd.usp.br/redecoop/>. Acesso em 01 jun. 2004.

RITTER, T.; GEMUNDEN, H. G.(2003). Network Competence: Its Impact on Innovation Success and its antecedents.Journal of Business Research, v. 56, n 9, p 691-697.

ROLLAND, C.; NURCAN, S.; GROSZ, G. (2000). A Decision making pattern for guiding the enterprise nowledge development process. Journal of Information and Software Technology, v. 42, p. 313-331.

SEBRAE (2000). O desempenho das MPEs da construção civil paulista. Disponível em: <http://www.sebraesp.com.br/novo/pesquisa/download_pdf/Constr_Civil.pdf > Acesso em 10 abr. 2004.

SEBRAE (2004a). Redes de empresas. Disponível em: <http://www.sebrae.com.br/br/cooperecrescer/redesdeempresas.asp> Acesso em 20 jun. 2004. 
SEBRAE (2004b). Subcontratação Industrial. Disponível em: <http://www2.sebraers.com.br/mercado/nacional/subcontrata_o_industrial/default.asp> Acesso em 20 jun. 2004.

SERRA, S. M. B. (2001). Diretrizes para gestão dos subempreiteiros. Tese (Doutorado) Escola Politécnica da Universidade de São Paulo. Departamento de Engenharia de Construção Civil. São Paulo- SP

SOIBELMAN, L.; CALDAS, C. H. S. (2000). O uso de extranets no gerenciamento de projetos: o exemplo norte americano. In: 8., Encontro Nacional de Tecnologia do Ambiente Construído (ENTAC),Anais... Salvador.

TERHAAG, O.; DRESSE, S.; KÖLSCHEID, W.; NIEDER, A. (1996): Final of ESPRIT Project "MOTION" (WP 1.2). Core Process, Core Competence, Core Product . Work Package 1.2 Final Report, WZL-Aachen.

TORKKELI, M.; TUOMINEN,M. (2002). The contribution of technology selection to core competences. International Journal of Production Economics v. 77, n. 3 p. 271-284.

WILK E. O. (1999). O Uso de uma Análise de Core Competences na Formulação de um Portfólio de Opções de Diversificação. Disponível em:

<http://dablium.tripod.com/artigo1.htm> Acesso em 13 maio de 2004.

YIN, R. K. (2001). Estudo de caso: Planejamento e métodos. São Paulo: Bookman Companhia Editorial. 


\section{APÊNDICE - Metodologia EKD.}

Para a realização do desenho da rede foi utilizada a metodologia Enterprise Knowledge Development (EKD). A metodologia EKD fornece uma forma sistematizada e controlada de analisar, entender, desenvolver e documentar uma organização e seus componentes, com uso da Modelagem Organizacional. (ROLLAND; NURCAN e GROSZ, 2000). O grupo de pesquisa, ao qual o trabalho pertence, adotou a metodologia como padrão para demonstrar a configuração da rede em todos os trabalhos.

Na Modelagem Organizacional ficam definidos os objetivos aos quais as empresas pretendem alcançar ou evitar. Os objetivos identificados e compartilhados com toda a equipe, atores que executam os processos, possibilitam a aquisição de informações que desenvolvem o sistema de informação, apóiam os objetivos do negócio e contribuem para realização dos processos para auxiliar os atores e controlar também alguns recursos.

O EKD é uma linguagem gráfica para visualização, especificação, construção e documentação de sistemas de software. Através da EKD é possível construir uma espécie de "planta” do sistema, incluindo aspectos conceituais, processos de negócios, funções do sistema, linguagens de programação, esquemas de banco de dados e componentes reutilizáveis. O EKD prescreve o desenvolvimento da especificação de requisitos como um escopo de atividades do grupo de trabalho (PÁDUA, 2001). O EKD auxilia o processo de conhecimento organizacional através de seus modelos que proporcionam várias visões da organização

Pádua (2001) reporta que o modelo fornece, de forma natural, uma possibilidade para os participantes entrarem em questões e fenômenos relacionados com sua parte do negócio e ver o impacto de suas decisões ou requisitos de todos os processos da organização. Os modelos proporcionam benefícios para a cultura e aprendizado organizacionais.

Neste sentido, apresenta-se um breve contexto sobre as Modelagens que serão exploradas neste projeto. O Modelo Organizacional contém um número de submodelos interrelacionados. Cada um representa algum aspecto da organização. De acordo com Pádua, (2000), os tipos de submodelos e as questões que eles abordam são:

- Modelo de Objetivos: idéias da organização. Descreve o que a organização e os empregados querem alcançar ou evitar, e quando. 
- Modelo de Regras do Negócio: regras do negócio são formuladas e consistentes com o Modelo de Objetivos. Regras do Negócio podem ser vistas como operacionalização ou limites dos objetivos.

- Modelo de Processos do Negócio: O Modelo de Processo de Negócio destina-se analisar o processo e o fluxo de informação e material da organização.

- Modelo de Atores e Recursos (MAR): é usado para descrever como se relacionam diferentes atores e recursos se relacionam, e como eles estão relacionados a componentes do Modelo de Objetivos, e a componentes do Modelo de Processos de Negócio.

Cada um dos modelos foi associado a um elemento proposto por Brito (2002a). Os “elementos nós” serão representados pelo submodelo de atores, os “elementos ligações” serão representados pelo submodelo de regras, os elementos posições serão representados pelo modelo de processos e os “elementos fluxos” então representados pelas setas entre o submodelo de atores e todos os submodelos. O submodelo de processos será utilizado para representar as tarefas executadas na obra; tem como entrada uma oportunidade de realização da tarefa e como saída a tarefa concluída, liberando assim uma próxima tarefa. (MACHADO e HEINECK, 2003). A representação gráfica dos modelos é feita na figura 11 e mostra uma interligação que estes submodelos possuem.

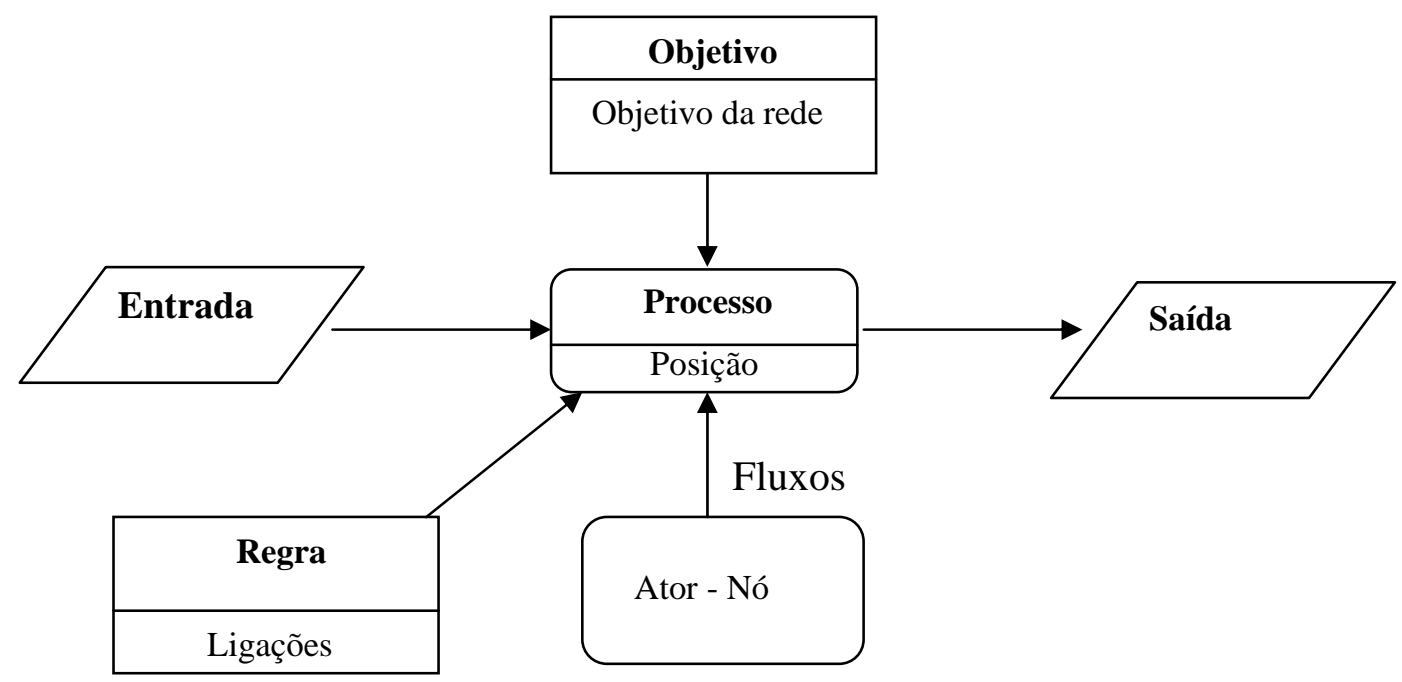

Figura 18 - Representação gráfica dos submodelos e seus respectivos elementos.

Estes modelos podem ser efetivamente usados para representar e discutir como projetar e melhorar processos organizacionais e como desenvolver estratégias futuras.

Os componentes do EKD são modelos conceituais que examinam a organização e seus requisitos de um número de perspectivas inter-relacionadas. Esses modelos são abstrações do 
mundo físico. Para dada organização, esses modelos irão constituir coletivamente o Modelo Organizacional. Alguns desses modelos podem conter informações relevantes que apontam a necessidade de avaliações de alternativas de situações operacionais. 
ANEXO A - Mapa da linha amarela da rede do metrô da cidade de São Paulo. 


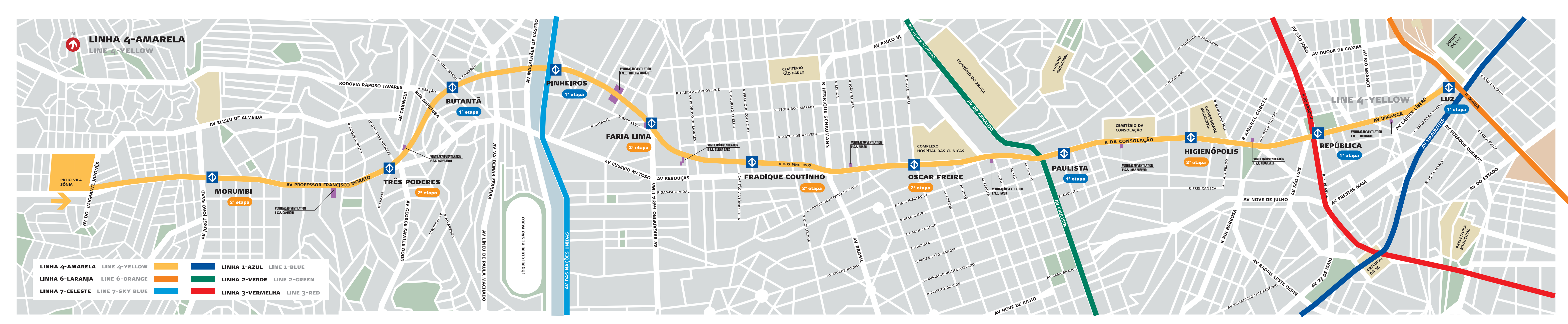

